\title{
\#USGS
}

science for a changing world

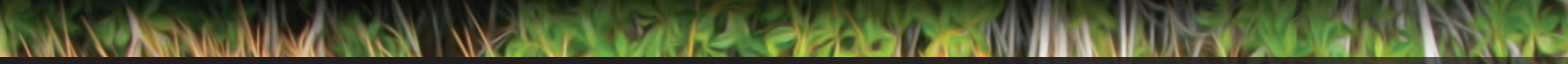

Prepared in cooperation with the

U.S. Geological Survey Greater Everglades Priority Ecosystems Science

\section{Estimation of Missing Water-Level Data for the Everglades Depth Estimation Network (EDEN), 2013 Update}

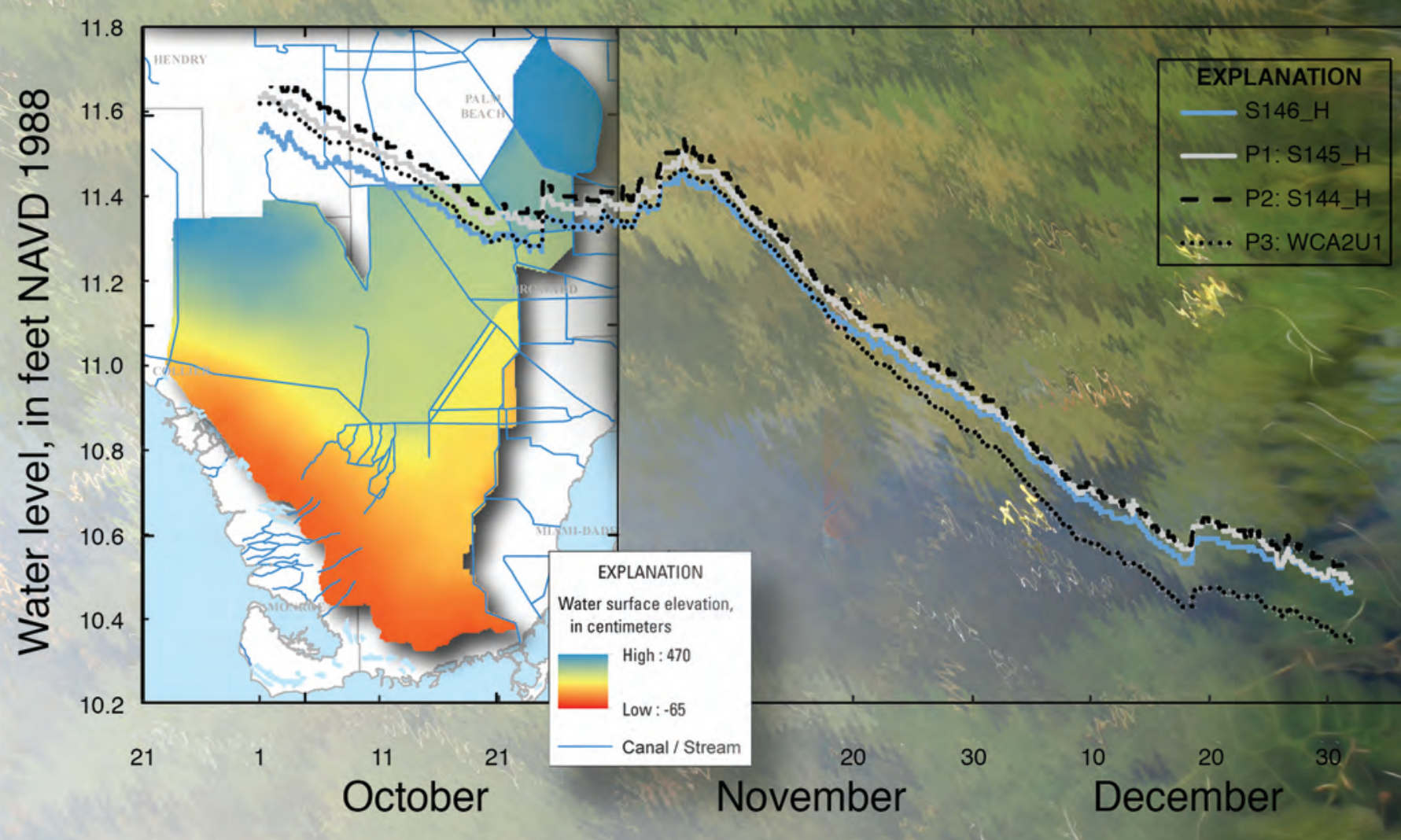

Open-File Report 2013-1251 


\section{Estimation of Missing Water-Level Data for the Everglades Depth Estimation Network (EDEN), 2013 Update}

Matthew D. Petkewich and Paul A. Conrads

Prepared in cooperation with the

U.S. Geological Survey Greater Everglades Priority Ecosystems Science

Open-File Report 2013-1251 


\title{
U.S. Department of the Interior SALLY JEWELL, Secretary
}

\section{U.S. Geological Survey Suzette M. Kimball, Acting Director}

\author{
U.S. Geological Survey, Reston, Virginia: 2013
}

For more information on the USGS - the Federal source for science about the Earth, its natural and living resources, natural hazards, and the environment, visit http://www.usgs.gov or call 1-888-ASK-USGS.

For an overview of USGS information products, including maps, imagery, and publications, visit http://www.usgs.gov/pubprod

To order this and other USGS information products, visit http://store.usgs.gov

Any use of trade, firm, or product names is for descriptive purposes only and does not imply endorsement by the U.S. Government.

Although this information product, for the most part, is in the public domain, it also may contain copyrighted materials as noted in the text. Permission to reproduce copyrighted items must be secured from the copyright owner.

Suggested citation:

Petkewich, M.D., and Conrads, P.A., 2013, Estimation of missing water-level data for the Everglades Depth Estimation Network (EDEN), 2013 update: U.S. Geological Survey Open-File Report 2013-1251, 45 p. 


\section{Contents}

Abstract
Introduction
Purpose and Scope
Description of Study Area
Estimation of Water-Level Data
Summary and Discussion

Appendix 1. EDEN station, type of station, operating agency, vertical datum conversion, location, and water-surface model status sorted by area ..........................................................12

Appendix 2. EDEN water-level estimation equations and performance statistics sorted

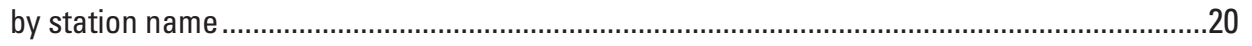

\section{Figures}

1. Map showing location of the 247 water-level stations used in the Everglades Depth Estimation Network surface-water model or used to estimate missing water-level data for stations in the surface-water model .................................................

2. Map showing Everglades Depth Estimation Network digital elevation model ..................3

3. Example of Everglades Depth Estimation Network water-surface map for a wet season day and a dry season day.

4. Graph showing measured and estimated water level for station S146_H for the period October 1, 2010, to December 31, 2010

5. Graph showing exceedance percentage for coefficient of determination for first, second, third predictor, and all 667 predictor water-level estimation equations

\section{Table}

1. Minimum, median, and maximum values for the summary statistics for 667 water-level estimation equations. 


\section{Conversion Factors}

\begin{tabular}{|c|c|c|}
\hline Multiply & By & To obtain \\
\hline \multicolumn{3}{|c|}{ Length } \\
\hline foot $(\mathrm{ft})$ & 0.3048 & meter $(\mathrm{m})$ \\
\hline \multicolumn{3}{|l|}{ SI to Inch/Pound } \\
\hline Multiply & By & To obtain \\
\hline \multicolumn{3}{|c|}{ Length } \\
\hline meter $(\mathrm{m})$ & 3.281 & foot (ft) \\
\hline
\end{tabular}

\section{Acronyms and Abbreviations}

$\begin{array}{ll}\text { BCNP } & \text { Big Cypress National Preserve } \\ \text { CERP } & \text { Comprehensive Everglades Restoration Plan } \\ \text { EDEN } & \text { Everglades Depth Estimation Network } \\ \text { ENP } & \text { Everglades National Park } \\ \text { GIS } & \text { geographic information system } \\ \text { ME } & \text { mean error } \\ \text { NAVD 1988 } & \text { North American Vertical Datum of 1988 } \\ \text { NGVD 1929 } & \text { National Geodetic Vertical Datum of 1929 } \\ \text { NWIS } & \text { National Water Information System } \\ \text { P1 } & \text { Predictor 1 } \\ \text { P2 } & \text { Predictor 2 } \\ \text { P3 } & \text { Predictor 3 } \\ \text { PME } & \text { percent model error } \\ \text { R } & \text { Pearson correlation coefficient } \\ \text { R } 2 & \text { coefficient of determination } \\ \text { RBF } & \text { radial basis function } \\ \text { RMSE } & \text { root mean square error } \\ \text { SFWMD } & \text { South Florida Water Management District } \\ \text { USGS } & \text { U.S. Geological Survey } \\ \text { WCA } & \text { water conservation area } \\ & \end{array}$




\title{
Estimation of Missing Water-Level Data for the Everglades Depth Estimation Network (EDEN), 2013 Update
}

\author{
By Matthew D. Petkewich and Paul A. Conrads
}

\section{Abstract}

The Everglades Depth Estimation Network is an integrated network of real-time water-level gaging stations, a ground-elevation model, and a water-surface elevation model designed to provide scientists, engineers, and water-resource managers with water-level and water-depth information (1991-2013) for the entire freshwater portion of the Greater Everglades. The U.S. Geological Survey Greater Everglades Priority Ecosystems Science provides support for the Everglades Depth Estimation Network in order for the Network to provide quality-assured monitoring data for the U.S. Army Corps of Engineers Comprehensive Everglades Restoration Plan. In a previous study, water-level estimation equations were developed to fill in missing data to increase the accuracy of the daily water-surface elevation model. During this study, those equations were updated because of the addition and removal of water-level gaging stations, the consistent use of water-level data relative to the North American Vertical Datum of 1988, and availability of recent data (March 1, 2006, to September 30,2011). Up to three linear regression equations were developed for each station by using three different input stations to minimize the occurrences of missing data for an input station. Of the 667 water-level estimation equations developed to fill missing data at 223 stations, more than 72 percent of the equations have coefficients of determination greater than 0.90 , and 97 percent have coefficients of determination greater than 0.70 .

\section{Introduction}

The Everglades Depth Estimation Network (EDEN) project was initiated to provide scientists working on the restoration of the Everglades with spatially continuous quality-assured and quality-controlled hydrologic data at any location within the freshwater part of the Greater Everglades. The EDEN is an integrated network of real-time water-level gaging stations, a ground-elevation model, and a water-surface elevation model designed to provide scientists, engineers, and water-resource managers with current (1991-2013) waterlevel and water-depth information for the entire freshwater portion of the Greater Everglades (Telis, 2005, 2006). The EDEN is presented on a grid consisting of more than fiftythousand grid cells and offers a consistent and documented dataset that can be used by scientists and water-resource managers to (1) guide large-scale field operations, (2) integrate hydrologic and ecological data and analyses, and (3) support biological and ecological restoration assessments that measure ecosystem responses to the Comprehensive Everglades Restoration Plan (U.S. Army Corps of Engineers, 1999). In addition, EDEN, with the integration of real-time data and models, provides opportunities for real-time evaluation of water-level conditions and water-resource management operation.

To estimate water depths in the Greater Everglades, geographic information system (GIS) models have been developed to determine the ground elevation and watersurface elevation for the freshwater portion of the Everglades. The water-depth estimates are the differences between the two surfaces. Data to support the ground-elevation model include land-surface elevation measurements at 400-meter (m) intervals at more than 50,000 sites (Desmond, 2003). Data to support the water-surface model include continuous water levels at 247 stations (fig. 1). The water-level gaging stations include 223 stations that are used to create water-surface elevation maps using the water-surface model and 24 stations (predictor sites) that are not used specifically for production of the water-surface maps, but can be used to estimate the water levels at the 223 stations, as necessary. Recently (2011-2013), 18 gaging stations that had been used in the model at one time have been discontinued by the operating agencies.

For the development of the ground-elevation model (Jones and Price, 2007a; Xie and others, 2011; Jones and others, 2012), the EDEN domain was divided into a large number of equal-sized 400- x 400-m cells that in total are referred to as the "grid" (Jones and Price, 2007b). The grid includes information on the characteristics of each cell, such as the centroid location, the area of the Everglades it represents, the average elevation, and the percentage of vegetation type 


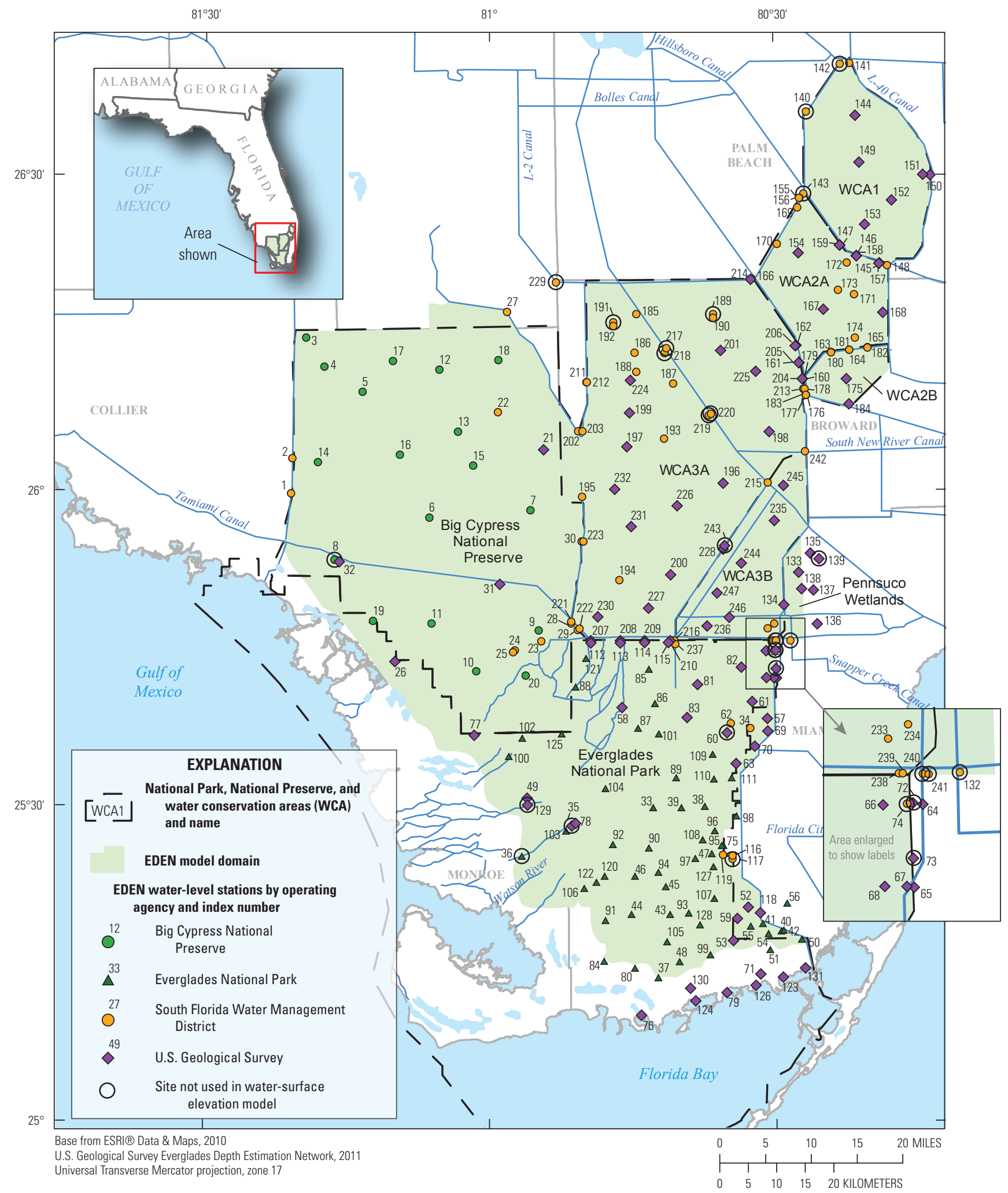

Figure 1. Location of the 247 water-level stations used in the Everglades Depth Estimation Network surfacewater model or used to estimate missing water-level data for stations in the surface-water model. The EDEN model domain is the freshwater part of the Greater Everglades. 
(open water/slough, wet prairie, sawgrass, upland, exotic, and other). This large number of highly accurate elevation data allowed for further refinement of the ground-elevation model. The geostatistical technique of kriging was selected for the EDEN ground-elevation model following extensive testing of multiple interpolation techniques. To account for variations within subregions of the EDEN area, individual geostatistical models were created for each water conservation area (WCA), the Everglades National Park (ENP), and portions of Big Cypress National Preserve (BCNP). These individual models were combined to create a single, 400-m-resolution groundelevation model for the EDEN domain (fig. 2).

A water-surface elevation model for the freshwater portion of the EDEN domain was developed in a GIS using the

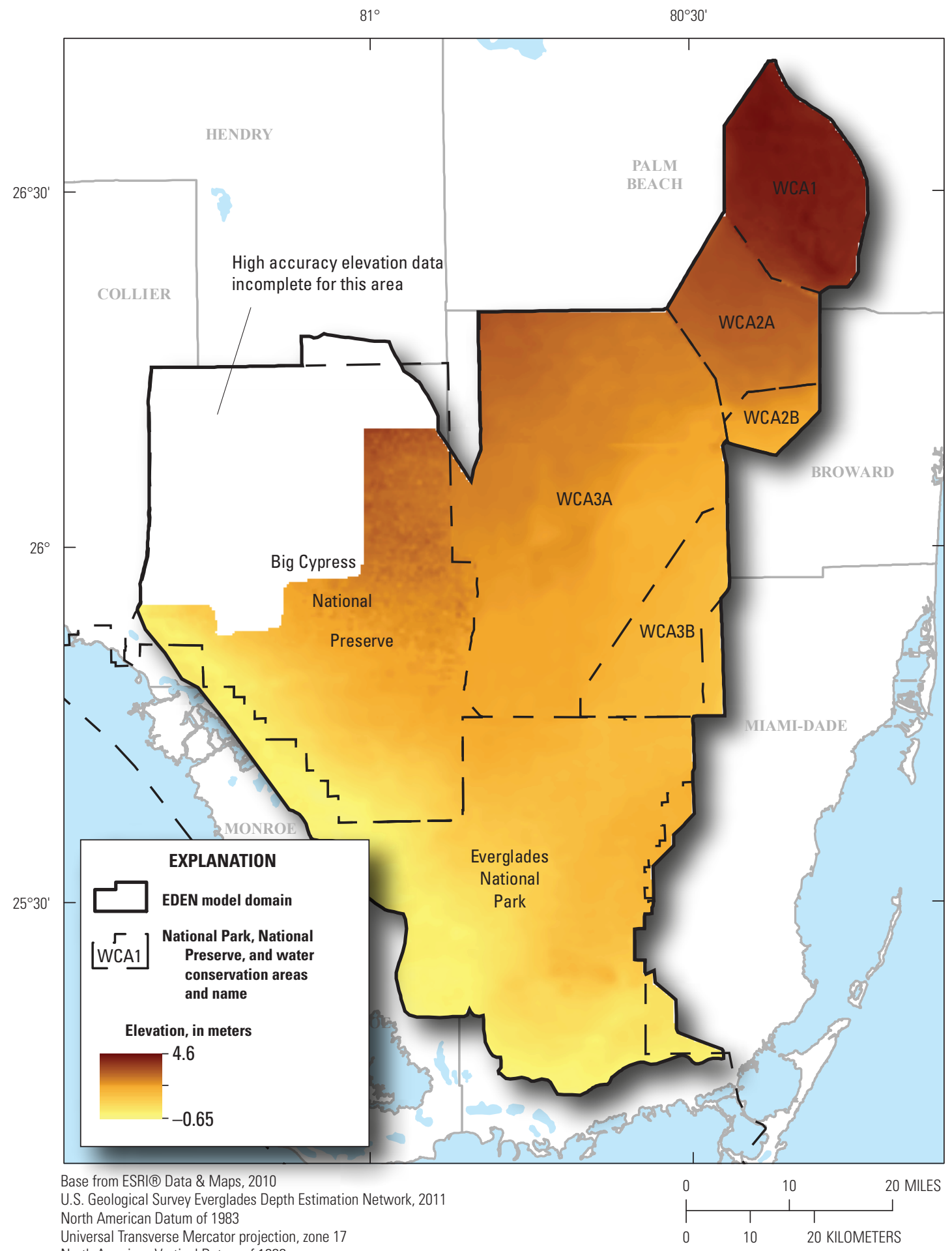

North American Vertical Datum of 1988

Figure 2. Everglades Depth Estimation Network digital elevation model. 
EDEN grid described above for the ground-elevation model (Pearlstine and others, 2007; Palaseanu and Pearlstine, 2008). The EDEN water-surface model interpolates measured daily water levels from 223 stations in the EDEN continuous monitoring network to the 400- $\mathrm{x} 400$-m cells of the grid by using radial basis functions (RBF) with multiquadric regression. The model produces a continuous water surface for any day within the period of record in the EDEN database. Examples of the water surface for two sample days are shown in figure 3.

Often, data for the 223-station network may be missing because of instrumentation failure or telemetry transmission problems. In addition, 13 stations currently (May 2013) do not have telemetry for real-time transmission of data. When data from a particular station are missing, the water-surface model does not use that station for generating the water-surface map for that day. The quality of the water-surface maps, therefore, can be diminished depending on the number of stations with missing data and the locations of those stations. To increase the accuracy of the daily water surface, water-level estimation equations were developed to fill missing data (Conrads and Petkewich, 2009). The original equations were developed in 2009 and used water-level data (January 2000 through August 2008) referenced to the same datum used for the specific site's data in the National Water Information System (NWIS) database (either the National Geodetic Vertical Datum of 1929 [NGVD 1929] or the North American Vertical Datum of 1988 [NAVD 1988]). Using the correct datum for the input variables was critical to compute accurate estimation of water level. For each station, one to four linear regression equations were developed to estimate missing data for the station.

Since the development of the equations in 2009, the EDEN data management and the gaging station network have undergone two substantial changes. The NWIS database was the EDEN's principal database, but now a separate EDEN database is used that can export all of the water-level data referenced to the vertical datum of NAVD 1988. With all data referenced to one datum, the need for two datums to estimate water levels was eliminated. In addition, since 2009,

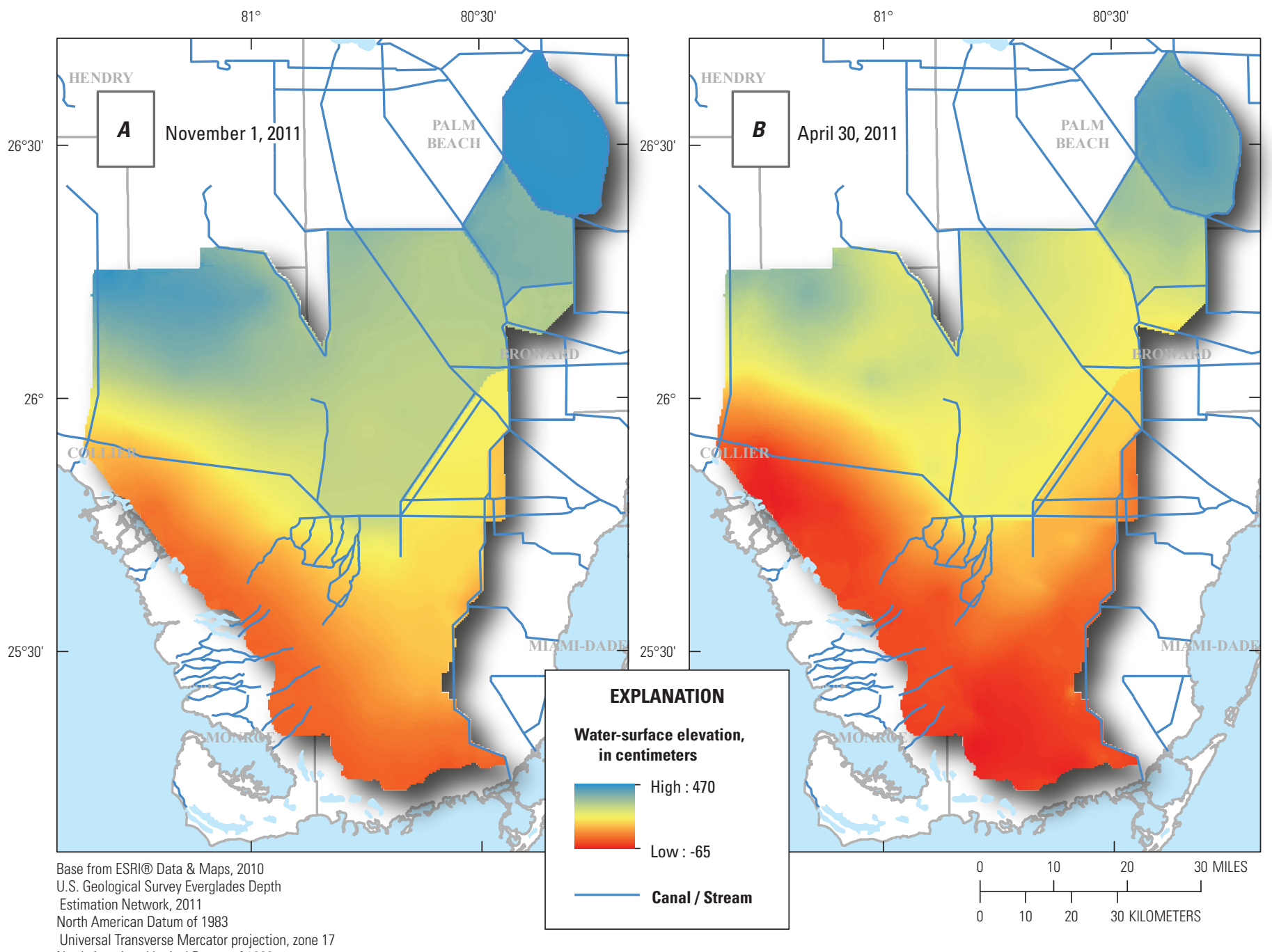

North American Vertical Datum of 1988

Figure 3. Example of Everglades Depth Estimation Network water-surface map for a wet season day and a dry season day. 
stations have been added to or removed from the EDEN. Because of these changes, new equations were developed using the current list of stations in the EDEN. Equations were developed using available data from March 1, 2006, to September 30, 2011. This specific period of time was selected for the development of the equations because data for this period had undergone all quality-assurance steps required by the operating agencies maintaining the gages. In addition, this period of time was selected based on break-point analysis, which indicated that this time period represented a period of uniform hydrologic behavior (Conrads and Benedict, 2013). Use of a period of record that spans periods of changing hydrologic behavior would decrease the ability of the equations to accurately predict recent missing data.

\section{Purpose and Scope}

The purpose of this report is to present updated waterlevel estimation equations and performance statistics for the gaging stations used in the EDEN water-surface elevation model. The development of the estimation equations was documented in a previously published report (Conrads and Petkewich, 2009). Sections of that report are updated in this report. For this report, the freshwater portion of the Greater Everglades (EDEN study area) includes BCNP, ENP, WCA1, WCA2, and WCA3 (fig. 1). The freshwater portion of the Greater Everglades is the area upstream of the coastal oligohaline wetlands as defined in the Comprehensive Everglades Restoration Plan (CERP; RECOVER, 2004). The temporal extent of the data used for the development of the equations is from March 1, 2006, to September 30, 2011. An important role of the USGS mission is to provide scientific information for the effective management of the Nation's water resources. The techniques presented in this report demonstrate how existing databases of continuous time-series data can be compiled and analyzed to assist researchers and resource managers to better understand complex natural systems and, therefore, better manage the resources of those systems. In particular, these techniques demonstrate how water-level data collected by various agencies can be integrated and used to minimize the amount of missing record. The techniques are readily applicable to other natural systems for evaluation and estimation of historical time-series data.

\section{Description of Study Area}

The Everglades is a vast wetland consisting of approximately 2.9 million acres covering much of southern Florida (fig. 1). The geographical extent for this report includes BCNP, ENP, WCA1, WCA2, and WCA3 as illustrated in figure 1. The Everglades primarily consist of peat soils and tall sawgrass that are interspersed with slightly raised tree islands covered by shrubs and woody vegetation (McPherson and others, 1995). Historically, the Everglades were an uninterrupted wetland that extended from Lake Okeechobee and flowed to the southwestern tip of Florida (Richardson and others, 1990). During the annual wet season (from about May to October), water levels would rise and inundate most of the land, producing seasonal flows into the Florida Bay and the Gulf of Mexico. In contrast, during the dry season, water levels declined and were near land surface (McPherson and others, 1995). This hydrologic pattern helped produce and sustain the unique ecosystem of the Everglades.

From the mid-1800s to the late 1900s, the flow patterns, and thus the ecosystem, of the Everglades have been substantially altered. Beginning in the mid-1800s, wetlands began to be drained and used for agricultural purposes and urban development such that by the early 1990 s, about 50 percent of the historic Everglades had been drained (McPherson and others, 1995). With population growth and increased agricultural production, flood mitigation and water use in South Florida became prominent concerns. To address those concerns, WCAs 1, 2, and 3 (fig. 1) were constructed by the U.S. Army Corps of Engineers in the 1940s with the goal of regulating water through an extensive series of levees and canals. In general, the WCAs store water during the wet season and supply water during the dry season. The combined effect of drained wetlands and water regulation introduced during the $1800 \mathrm{~s}$ and 1900s diverts an estimated 40 percent of the water originally flowing through the Everglades (McPherson and others, 1995). The substantial changes in land use and flow patterns within the Everglades have had adverse environmental effects on the hydrology, water quality, and native plant and animal communities (McPherson and others, 1995). Since the late 1900 s, through the collaboration of Federal, State, and private agencies, substantial focus has been given to mitigate these adverse effects and, where possible, to begin restoration of the ecosystem and ecological communities of the Everglades.

\section{Data-Collection Network}

The EDEN database is a MySQL server database that is composed of hourly water-level data from 247 gaging stations and includes marsh, river, or control structure stations (appendix 1) operated by the BCNP, ENP, the South Florida Water Management District (SFWMD), and the U.S. Geological Survey (USGS). In this report, the names of the EDEN stations follow the naming convention used by EDEN (http://sofia. usgs.gov/eden/explanation.php\#stationname) and are generally similar to the names used by the agency that maintains the station. The datasets used to generate water-level surfaces with the EDEN water-surface elevation model are available on the EDEN Web page on the South Florida Information Access Web site-http://sofia.usgs.gov/eden/index.php.

Water-level data provided by the operating agencies use either NGVD 1929 or NAVD 1988. Data from BCNP, ENP, and SFWMD use NGVD 1929 and are converted to NAVD 1988 when loaded into the EDEN database. The datum for the USGS-operated stations are station specific 
and are stored in the EDEN database using the same datum that is used by the USGS and converted to NAVD 1988 when exported from the database for use in the water-surface elevation model.

\section{Estimation of Water-Level Data}

Water-level estimation equations are in the form of $y=m x+b$, where $y$ is the estimated value, $m$ is the slope, $x$ is the value from the input ("predictor") station, and b is the $y$-intercept. The procedure used to develop estimation equations is described in detail in Conrads and Petkewich (2009). The equations that are presented in this report were developed by using daily water-level data from March 1, 2006, to September 30, 2011, and can be used to estimate daily or hourly values.

The estimation of missing water-level data for the 223 stations used in the water-surface-elevation model is computed within a Microsoft Access ${ }^{\circledR}$ database (Conrads and Petkewich, 2009) after the data are retrieved from the individual agencies and prior to generating daily water-surface maps. Currently (May 2013), all water-level data stored in the EDEN database are referenced to NAVD 1988 except for data for 62 USGS stations that are referenced to NGVD 1929. Equations that included data from any of these 62 stations were programmed within the Microsoft Access ${ }^{\circledR}$ database using appropriate datum conversion factors so that estimates of missing data were accurate for each specific station. For example, equations stored in the Microsoft Access ${ }^{\circledR}$ database for a station (y) with an NAVD 1988 datum and that uses a station (x) having an NGVD 1929 datum include the factor converting the station $x$ data from NGVD 1929 to NAVD 1988 prior to using the estimation equation for estimating missing data. All data stored in the EDEN database include a data field indicating whether the data were measured or estimated. Data exported from the EDEN database and used in the creation of the EDEN watersurface maps use a common NAVD 1988.

The 667 water-level estimation equations are presented in appendix 2 and are listed by station name in alphanumerical order. For each station, one to three estimation equations are listed in appendix 2 (predictors-P1, P2, and P3) along with the values for the slope and y-intercept. Descriptive statistics for the stations and measures of prediction accuracy for the estimation equations also are listed. Descriptive statistics include minimum, maximum, mean, median, range, standard deviation, sample variance, and number of observations of the daily water-surface elevations for the period of record analyzed. The goodness-of-fit statistics presented in appendix 2 for the 667 equations are the Pearson correlation coefficient (R), coefficient of determination $\left(\mathrm{R}^{2}\right)$, root mean square error (RMSE), standard error, and percent model error (PME, computed as the RMSE divided by the range of the measured data).
Each statistic measures a different aspect of the accuracy of the prediction equations. Estimation accuracy commonly is reported in terms of $\mathrm{R}^{2}$ and is interpreted as the goodness-of-fit of an equation or model. A second interpretation may answer the question, "How much information does one variable or a group of variables provide about the behavior of another variable?" In the first context, an $\mathrm{R}^{2}=0.6$ might be disappointing, whereas in the latter, it is merely an accounting of how much information is shared by the variables being used.

The standard error is the measure of the scatter of the actual observations about the regression line and is the standard deviation of the error of the predicted values in the regression. The standard error can be used to compute confidence intervals for the predictions.

The mean error (ME) and RMSE statistics provide a measure of the prediction accuracy of the estimation equations. The ME is a measure of the bias of model predictionswhether the model over- or underpredicts the measured data. The ME is the overall adjustment of the estimated values required to equal the measured values; therefore, positive and negative MEs indicate an over- or underprediction bias by the model, respectively. MEs near zero may be misleading because negative and positive discrepancies in the simulations can cancel each other. RMSEs address the limitations of ME by computing the magnitude, rather than the direction (sign) of the discrepancies. The units of the ME and RMSE statistics are the same as the variable simulated by the model. ME and percent model bias (ME divided by the mean observed value) were essentially zero for all equations and, therefore, are not included in the goodness-of-fit statistics. ME and percent model bias equal zero because simple linear regression equations, such as those described in this report, inherently minimize the sum of the residuals (error) between the estimates and the measured data. The sum of the residuals, and therefore, ME, are zero for all stations.

The accuracy of the models, as given by RMSE, should be evaluated with respect to the range of the output variable. A model may have a low RMSE, but if the range of the output variable is small, the model may only be accurate for a limited range of conditions and the model error may be a relatively large percentage of the model response. Likewise, a model may have a large RMSE, but if the range of the output variable is large, the model error may be a relatively small percentage of the total model response. The PME is computed by dividing the RMSE by the range of the measured data.

The selection and order of the estimation equations generally were based on the overall goodness-of-fit represented by $\mathrm{R}^{2}$ and RMSE and the proximity of the input station to the station of interest. In some instances, estimation equations were selected because the input station allowed fitting a particular part of the year (wet season or dry season) better than all other stations. The areas where the station and input stations are located also are listed in appendix 2. For some stations, the P1 predictor may not be the adjacent input station because the goodness-of-fit statistics for the P1 station are better than the P2 or P3 stations. Station S140_H only has one estimation 
equation because the correlations between station S140_H and all of the other EDEN stations are less than 50 percent and, therefore, provide poor estimates of S140_H water levels.

The following is an example of how to use appendix 2. Find the station of interest in appendix 2, for example S146_H, a marsh structure in Water Conservation Area 2A. The three input stations, or predictors, are S145_H, S144_H, and WCA2U1 and are listed as P1, P2, and P3, respectively. If needed, use the datum correction value located in appendix 1 to convert the input station data to NAVD 1988. The three estimation equations are

$$
\begin{aligned}
& \text { P1: } Y_{\text {estimated }}=1.016\left(\mathrm{X}_{\mathrm{S} 145 \__{\mathrm{H}}}\right)-0.163, \\
& \mathrm{P} 2: \mathrm{Y}_{\text {estimated }}=1.033\left(\mathrm{X}_{\mathrm{S} 144 \_\mathrm{H}}\right)-0.290 \text {, and } \\
& \mathrm{P} 3: \mathrm{Y}_{\text {estimated }}=1.155\left(\mathrm{X}_{\mathrm{WCA2U1}}\right)-1.884 .
\end{aligned}
$$

The $\mathrm{Y}_{\text {estimated }}$ station is $\mathrm{S} 146 \_\mathrm{H}$, and $\mathrm{X}$ is the input (predictor) station. To estimate missing water-level data from station S146_H, the equation for the first predictor station $\mathrm{P} 1(\mathrm{~S} 145 \mathrm{H})$ is used with measured data from S145 H. In the event that the data for $\mathrm{S} 145 \mathrm{H}$ also are missing, then the equation for predictor station $\mathrm{P} 2$ (station S144_H) is used to estimate the missing water-level data using data from station S144_H. In the event that data for both S145_H and S144_H are missing, the equation and data for predictor station $\mathrm{P} 3$ (WCA2U1) are used. If all predictor stations are missing, no estimate is computed.

The $\mathrm{R}^{2} \mathrm{~s}$ for the three estimation equations are 0.997 , 0.992 , and 0.954 , respectively. The RMSEs for the equations range from 0.058 to 0.208 foot. The percent model error is less than 4 percent for each of the three predictor equations, and all three predictor stations are located in Water Conservation Area 2 (appendix 2). The measured and estimated water levels for station S146_H are shown in figure 4.

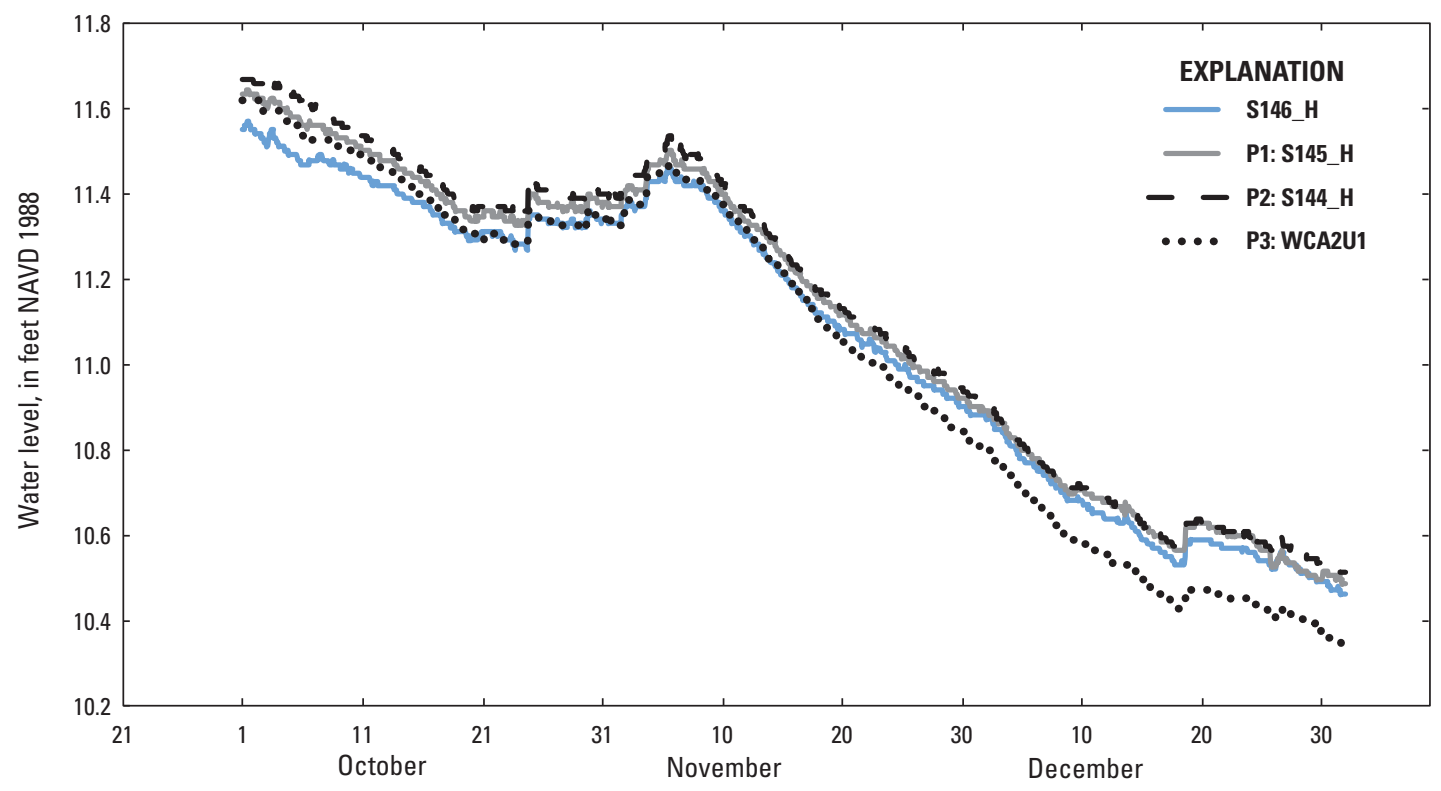

Figure 4. Graph showing measured and estimated water level for station S146_H for the period October 1, 2010, to December 31, 2010. 
The majority of the water-level estimation equations provide good estimates for missing values. Figure 5 shows the exceedance frequencies of the $\mathrm{R}^{2} \mathrm{~s}$ for the $\mathrm{P} 1, \mathrm{P} 2$, and $\mathrm{P} 3$ estimation equations and the cumulative frequency for all 667 predictor equations. More than 99 percent of the $223 \mathrm{P} 1$ equations have $\mathrm{R}^{2} \mathrm{~s}$ greater than 0.70 and over 83 percent have $\mathrm{R}^{2} \mathrm{~s}$ greater than 0.90 . Fifty percent of all 667 equations have $\mathrm{R}^{2} \mathrm{~s}$ greater than 0.95 , more than 72 percent (484 equations) have $\mathrm{R}^{2} \mathrm{~s}$ greater than 0.90 , and more than 97 percent (647 equations) have $R^{2} s$ greater than 0.70 . Summary statistics including minimum, median, and maximum observed waterlevel values for all 667 equations are listed in table 1. Caution should be used when using equations with particularly poor performance statistics.

Table 1. Minimum, median, and maximum values for the summary statistics for 667 water-level estimation equations.

$\left[\mathrm{R}^{2}\right.$, coefficient of determination; RMSE, root mean square error]

\begin{tabular}{lccc}
\hline \multicolumn{1}{c}{ Statistic } & Minimum & Median & Maximum \\
\hline $\mathrm{R}^{2}$ & 0.292 & 0.949 & 1.000 \\
RMSE & 0.013 & 0.165 & 1.036 \\
Standard error & 0.010 & 0.160 & 0.680 \\
Percent model error & $0.25 \%$ & $4.3 \%$ & $20.3 \%$ \\
\hline
\end{tabular}

\section{Summary and Discussion}

The Everglades Depth Estimation Network (EDEN) is an integrated network of real-time water-level gaging stations, a ground-elevation model, and a water-surface elevation model. The network provides scientists, engineers, and water-resource managers with water-level and water-depth information from 1991 to 2013 for the entire freshwater portion of the Greater Everglades. A spatially-continuous interpolated water surface across the Greater Everglades is generated from daily median water-level values by using the EDEN water-surface elevation model. Missing or erroneous data diminish the quality of the modeled water surfaces. To increase the accuracy of the daily water-surface model, an application was developed to estimate water levels to fill data gaps. Missing data were estimated by developing linear regression equations for each station. To minimize the inability to estimate data due to missing data from an input station, one to three regression equations were developed for each station by using different input stations. For each station, an order was established for the regression equation to be used to fill a data gap. The 667 equations, representing 223 stations, were incorporated into a database application that automatically estimates missing records. The performance statistics computed for each equation provides documentation of the goodness-of-fit of the equations. In addition, although the majority of the equations provide satisfactory estimations of water levels, the performance statistic provides a prioritization for identifying stations where improved equations are needed to provide more satisfactory water-level estimates.

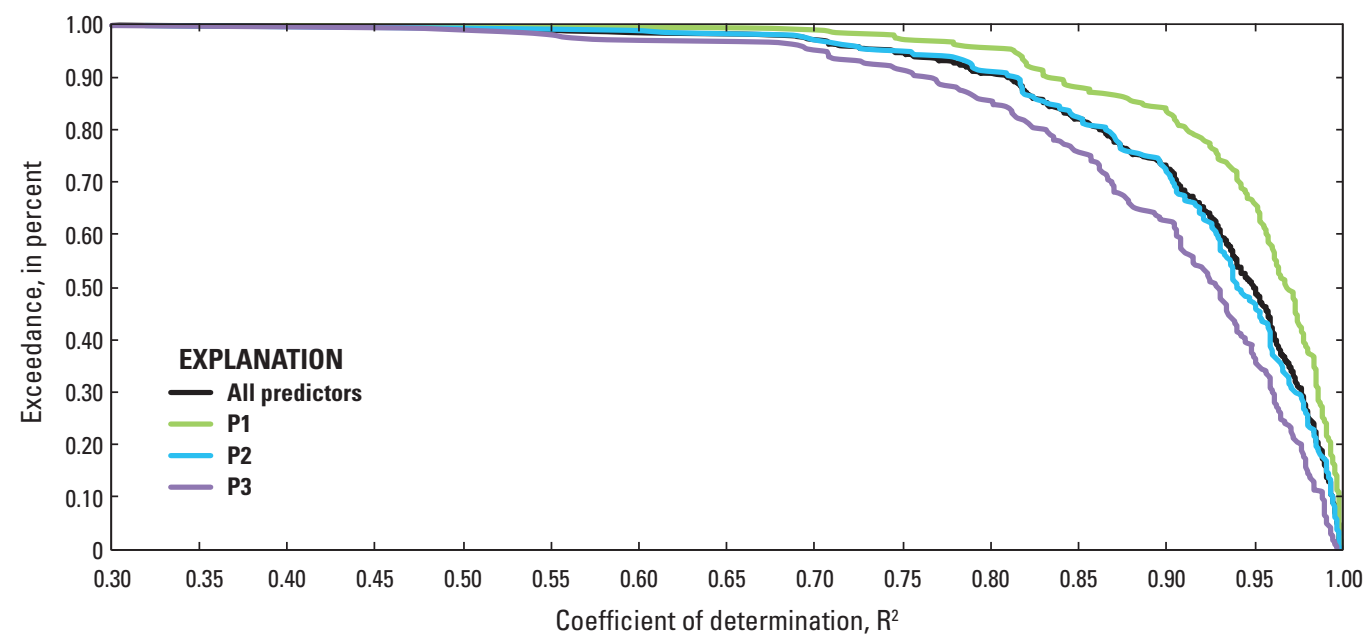

Figure 5. Graph showing exceedance percentage for coefficient of determination for first, second, third predictor, and all 667 predictor water-level estimation equations. 


\section{References Cited}

Conrads, P.A., and Benedict, S.T., 2013, Analysis of changes in water-level dynamics at selected sites in the Florida Everglades: U.S. Geological Survey Scientific Investigations Report 2012-5286, 36 p., accessed July 25, 2013, at http:// pubs.usgs.gov/sir/2012/5286.

Conrads, P.A., and Petkewich, M.D., 2009, Estimation of missing water-level data for the Everglades Depth Estimation Network (EDEN): U.S. Geological Survey Open-File Report 2009-1120, 53 p.

Desmond, G.D., 2003, Measuring and mapping the topography of the Florida Everglades for ecosystem restoration: U.S. Geological Survey Fact Sheet 021-03, 4 p.

Jones, J.W., Desmond, G.B., Henkle, C., and Glover, R., 2012, An approach to regional wetland digital elevation model development using a differential global positioning system and a custom-built helicopter-based surveying system: International Journal of Remote Sensing, v. 33, no. 2, p. $450-465$.

Jones, J.W., and Price, S.D., 2007a, Everglades Depth Estimation Network (EDEN) digital elevation model research and development: U.S. Geological Survey Open-File Report 2007-1034, 29 p.

Jones, J.W., and Price, S.D., 2007b, Conceptual design of the Everglades Depth Estimation Network (EDEN) grid: U.S. Geological Survey Open-File Report 2007-1200, 20 p.

McPherson, B.F., Higer, A.L., Gerould, S., and Kantrowitz, I.H., 1995, South Florida Ecosystem Program of the U.S. Geological Survey: U.S. Geological Survey Fact Sheet FS-134-95, accessed June 19, 2012, at http://sofia.usgs.gov/publications/ fs/134-95/index.html.

Palaseanu, M., and Pearlstine, L., 2008, Estimation of water surface elevations for the Everglades, Florida: Computers and Geosciences, doi:10.1016/j.cageo.2007.08.004.
Pearlstine, L., Higer, A., Palaseanu, M., Fujisaki, I., and Mazzotti, F., 2007, Spatially continuous interpolation of water stage and water depths using the Everglades Depth Estimation Network (EDEN): Gainesville, Fla., Institute of Food and Agriculture, University of Florida, CIR1521, 18 p., 2 apps.

RECOVER, 2004, CERP monitoring and assessment plan: Part 1-Monitoring and Supporting Research, REstoration Coordination and VERification Team (RECOVER): U.S. Army Corps of Engineers and South Florida Water Management District.

Richardson, J.R., Bryant, W.L., Kitchens, W.M., Mattson, J.E., and Pope, K.R., 1990, An evaluation of the refuge habitats and relationships to water quality, quantity, and hydroperiods-A synthesis report: Gainesville, Fla., Florida Cooperative Fish and Wildlife Research Unit, University of Florida.

Telis, P.A., 2005, Project description, South Florida Surface Water Monitoring Network for the Support of MAP Projects (known as EDEN, Everglades Depth Estimation Network), accessed October 2, 2007, at http://sofia.usgs.gov/projects/ eden/.

Telis, P.A., 2006, The Everglades Depth Estimation Network (EDEN) for support of ecological and biological assessments: U.S. Geological Survey Fact Sheet 2006-3087, 4 p.

U.S. Army Corps of Engineers, 1999, Central and southern Florida project, comprehensive review study - Final integrated feasibility report and programmatic environmental impact statement: Jacksonville, Fla., variously paged, 4 annexes, 15 apps.

Xie, Z., Liu, Z., Jones, J.W., Higer, A.L., and Telis, P.A., 2011, Landscape unit based digital elevation model development for the freshwater wetlands within the Arthur C. Marshall Loxahatchee National Wildlife Refuge, Southeastern Florida: Applied Geography, v. 31, issue 2, p. 401-412. 



\section{Appendixes}

1. EDEN station, type of station, operating agency, vertical datum conversion, location, and water-surface model status sorted by area................................................12

2. EDEN water-level estimation equations and performance statistics sorted by station name 
Appendix 1. EDEN station, type of station, operating agency, vertical datum conversion, location, and water-surface model status sorted by area.

[EDEN, Everglades Depth Estimation Network; NWIS, National Water Information System; NGVD 1929, National Geodetic Vertical Datum of 1929; NAVD 1988, North American Vertical Datum of 1988; UTM, Universal Transverse Mercator; BCNP, Big Cypress National Preserve; ENP, Everglades National Park; SFWMD,

South Florida Water Management District; USGS, U.S. Geological Survey; ${ }^{\circ}$, degrees; ', minutes; ", seconds]

\begin{tabular}{|c|c|c|c|c|c|c|c|c|c|}
\hline $\begin{array}{l}\text { EDEN } \\
\text { station } \\
\text { name }\end{array}$ & $\begin{array}{c}\text { Index } \\
\text { number } \\
\text { (see } \\
\text { fig. 1) }\end{array}$ & $\begin{array}{c}\text { Type of } \\
\text { station } \\
\text { (physical } \\
\text { location of } \\
\text { station) }\end{array}$ & $\begin{array}{c}\text { Operating } \\
\text { agency }\end{array}$ & 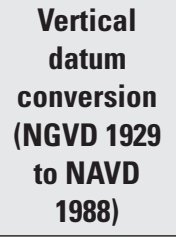 & Latitude & Longitude & $\begin{array}{c}\text { UTM } \\
\text { Easting, } \\
\text { in meters }\end{array}$ & $\begin{array}{c}\text { UTM } \\
\text { Northing, } \\
\text { in meters }\end{array}$ & $\begin{array}{c}\text { Gage } \\
\text { used in } \\
\text { water- } \\
\text { suface } \\
\text { model? }\end{array}$ \\
\hline \multicolumn{10}{|c|}{ Big Cypress National Preserve } \\
\hline BARW4 & 1 & Marsh & SFWMD & -1.37 & $25^{\circ} 59^{\prime} 41.57^{\prime \prime}$ & $81^{\circ} 20^{\prime} 49.25^{\prime \prime}$ & 465270.022 & 2875162.989 & Yes \\
\hline BARW6A & 2 & Marsh & SFWMD & -1.39 & $26^{\circ} 03^{\prime} 04.29^{\prime \prime}$ & $81^{\circ} 20^{\prime} 40.7^{\prime \prime}$ & 465524.177 & 2881398.550 & Yes \\
\hline BCA1 & 3 & Marsh & BCNP & -1.39 & $26^{\circ} 14^{\prime} 33^{\prime \prime}$ & $81^{\circ} 19^{\prime} 14^{\prime \prime}$ & 467985.596 & 2902579.231 & Yes \\
\hline BCA2 & 4 & Marsh & BCNP & -1.39 & $26^{\circ} 11^{\prime} 46^{\prime \prime}$ & $81^{\circ} 17^{\prime} 19^{\prime \prime}$ & 471164.524 & 2897434.259 & Yes \\
\hline $\mathrm{BCA} 3$ & 5 & Marsh & BCNP & -1.39 & $26^{\circ} 09^{\prime} 24^{\prime \prime}$ & $81^{\circ} 13^{\prime} 18^{\prime \prime}$ & 477845.590 & 2893052.762 & Yes \\
\hline BCA4 & 6 & Marsh & BCNP & -1.43 & $25^{\circ} 57^{\prime} 26^{\prime \prime}$ & $81^{\circ} 06^{\prime} 14^{\prime \prime}$ & 489599.276 & 2870950.611 & Yes \\
\hline BCA5 & 7 & Marsh & BCNP & -1.46 & $25^{\circ} 58^{\prime} 06^{\prime \prime}$ & $80^{\circ} 55^{\prime} 35^{\prime \prime}$ & 507368.803 & 2872179.036 & Yes \\
\hline BCA8 & 8 & Marsh & BCNP & -1.39 & $25^{\circ} 53^{\prime} 25^{\prime \prime}$ & $81^{\circ} 16^{\prime} 13^{\prime \prime}$ & 472926.090 & 2863560.772 & No \\
\hline BCA9 & 9 & Marsh & BCNP & -1.5 & $25^{\circ} 46^{\prime} 42^{\prime \prime}$ & $80^{\circ} 54^{\prime} 44^{\prime \prime}$ & 508801.018 & 2851138.964 & Yes \\
\hline BCA10 & 10 & Marsh & BCNP & -1.43 & $25^{\circ} 42^{\prime} 49^{\prime \prime}$ & $81^{\circ} 01^{\prime} 19^{\prime \prime}$ & 497798.554 & 2843968.889 & Yes \\
\hline BCA11 & 11 & Marsh & BCNP & -1.43 & $25^{\circ} 47^{\prime} 21^{\prime \prime}$ & $81^{\circ} 06^{\prime} 00^{\prime \prime}$ & 489974.434 & 2852339.526 & Yes \\
\hline BCA12 & 12 & Marsh & BCNP & -1.39 & $26^{\circ} 11^{\prime} 29^{\prime \prime}$ & $81^{\circ} 05^{\prime} 12^{\prime \prime}$ & 491340.702 & 2896882.120 & Yes \\
\hline BCA13 & 13 & Marsh & BCNP & -1.39 & $26^{\circ} 05^{\prime} 35^{\prime \prime}$ & $81^{\circ} 03^{\prime} 13^{\prime \prime}$ & 494638.959 & 2885990.323 & Yes \\
\hline BCA14 & 14 & Marsh & BCNP & -1.39 & $26^{\circ} 02^{\prime} 40^{\prime \prime}$ & $81^{\circ} 18^{\prime} 00^{\prime \prime}$ & 469987.921 & 2880640.293 & Yes \\
\hline BCA15 & 15 & Marsh & BCNP & -1.42 & $26^{\circ} 02^{\prime} 23^{\prime \prime}$ & $81^{\circ} 01^{\prime} 36^{\prime \prime}$ & 497325.257 & 2880093.253 & Yes \\
\hline BCA16 & 16 & Marsh & BCNP & -1.39 & $26^{\circ} 03^{\prime} 24^{\prime \prime}$ & $81^{\circ} 09^{\prime} 20^{\prime \prime}$ & 484432.601 & 2881978.748 & Yes \\
\hline BCA17 & 17 & Marsh & $\mathrm{BCNP}$ & -1.36 & $26^{\circ} 12^{\prime} 18^{\prime \prime}$ & $81^{\circ} 10^{\prime} 05^{\prime \prime}$ & 483203.487 & 2898406.983 & Yes \\
\hline BCA18 & 18 & Marsh & $\mathrm{BCNP}$ & -1.41 & $26^{\circ} 12^{\prime} 24^{\prime \prime}$ & $80^{\circ} 58^{\prime} 59^{\prime \prime}$ & 501686.055 & 2898580.730 & Yes \\
\hline BCA19 & 19 & Marsh & BCNP & -1.41 & $25^{\circ} 47^{\prime} 35^{\prime \prime}$ & $81^{\circ} 12^{\prime} 08^{\prime \prime}$ & 479719.224 & 2852793.274 & Yes \\
\hline BCA20 & 20 & Marsh & $\mathrm{BCNP}$ & -1.47 & $25^{\circ} 42^{\prime} 23^{\prime \prime}$ & $80^{\circ} 56^{\prime} 05^{\prime \prime}$ & 506542.122 & 2843182.064 & Yes \\
\hline EDEN_6 & 21 & Marsh & USGS & -1.45 & $26^{\circ} 03^{\prime} 55^{\prime \prime}$ & $80^{\circ} 54^{\prime} 14^{\prime \prime}$ & 509613.256 & 2882916.516 & Yes \\
\hline L28_GAP & 22 & Marsh & SFWMD & -1.42 & $26^{\circ} 07^{\prime} 28^{\prime \prime}$ & $80^{\circ} 59^{\prime} 00^{\prime \prime}$ & 501659.440 & 2889475.269 & Yes \\
\hline LOOP1_T & 23 & Structure & SFWMD & -1.48 & $25^{\circ} 45^{\prime} 40^{\prime \prime}$ & $80^{\circ} 54^{\prime} 28^{\prime \prime}$ & 509241.256 & 2849228.291 & Yes \\
\hline LOOP2_H & 24 & Structure & SFWMD & -1.47 & $25^{\circ} 44^{\prime} 48^{\prime \prime}$ & $80^{\circ} 57^{\prime} 14^{\prime \prime}$ & 504624.731 & 2847630.735 & Yes \\
\hline LOOP2_T & 25 & Structure & SFWMD & -1.47 & $25^{\circ} 44^{\prime} 48^{\prime \prime}$ & $80^{\circ} 57^{\prime} 15^{\prime \prime}$ & 504601.423 & 2847616.897 & Yes \\
\hline MO-216 & 26 & Marsh & USGS & -1.42 & $25^{\circ} 43^{\prime} 44.276^{\prime \prime}$ & $81^{\circ} 09^{\prime} 51.595^{\prime \prime}$ & 483516 & 2845679 & Yes \\
\hline S190_T & 27 & Structure & SFWMD & -1.57 & $26^{\circ} 16^{\prime} 60^{\prime \prime}$ & $80^{\circ} 58^{\prime} 04^{\prime \prime}$ & 503213.055 & 2907051.935 & Yes \\
\hline S343A_T & 28 & Structure & SFWMD & -1.54 & $25^{\circ} 47^{\prime} 20^{\prime \prime}$ & $80^{\circ} 51^{\prime} 20^{\prime \prime}$ & 514478.459 & 2852324.337 & Yes \\
\hline S343B_T & 29 & Structure & SFWMD & -1.53 & $25^{\circ} 46^{\prime} 41^{\prime \prime}$ & $80^{\circ} 50^{\prime} 39^{\prime \prime}$ & 515620.347 & 2851104.986 & Yes \\
\hline S344_T & 30 & Structure & SFWMD & -1.47 & $25^{\circ} 55^{\prime} 08^{\prime \prime}$ & $80^{\circ} 50^{\prime} 12^{\prime \prime}$ & 516353.546 & 2866724.152 & Yes \\
\hline $\begin{array}{l}\text { Tamiami_Canal_40- } \\
\text { Mile_Bend_to_- } \\
\text { Monroe }\end{array}$ & 31 & Marsh & USGS & -1.46 & $25^{\circ} 51^{\prime} 05^{\prime \prime}$ & $80^{\circ} 58^{\prime} 50^{\prime \prime}$ & 501948 & 2859226 & Yes \\
\hline $\begin{array}{l}\text { Tamiami_Canal_ } \\
\text { Monroe_to_Car- } \\
\text { nestown }\end{array}$ & 32 & Marsh & USGS & -1.39 & $25^{\circ} 53^{\prime} 14.44^{\prime \prime}$ & $81^{\circ} 15^{\prime} 42.61^{\prime \prime}$ & 473771 & 2863234 & Yes \\
\hline
\end{tabular}


Appendix 1. EDEN station, type of station, operating agency, vertical datum conversion, location, and water-surface model status sorted by area.-Continued

[EDEN, Everglades Depth Estimation Network; NWIS, National Water Information System; NGVD 1929, National Geodetic Vertical Datum of 1929; NAVD 1988, North American Vertical Datum of 1988; UTM, Universal Transverse Mercator; BCNP, Big Cypress National Preserve; ENP, Everglades National Park; SFWMD,

South Florida Water Management District; USGS, U.S. Geological Survey; ${ }^{\circ}$, degrees; ', minutes; ", seconds]

\begin{tabular}{|c|c|c|c|c|c|c|c|c|c|}
\hline $\begin{array}{c}\text { EDEN } \\
\text { station } \\
\text { name }\end{array}$ & $\begin{array}{c}\text { Index } \\
\text { number } \\
\text { (see } \\
\text { fig. 1) }\end{array}$ & $\begin{array}{l}\text { Type of } \\
\text { station } \\
\text { (physical } \\
\text { location of } \\
\text { station) }\end{array}$ & $\begin{array}{l}\text { Operating } \\
\text { agency }\end{array}$ & $\begin{array}{c}\text { Vertical } \\
\text { datum } \\
\text { conversion } \\
\text { (NGVD 1929 } \\
\text { to NAVD } \\
1988 \text { ) } \\
\end{array}$ & Latitude & Longitude & $\begin{array}{c}\text { UTM } \\
\text { Easting, } \\
\text { in meters }\end{array}$ & $\begin{array}{c}\text { UTM } \\
\text { Northing, } \\
\text { in meters }\end{array}$ & $\begin{array}{c}\text { Gage } \\
\text { used in } \\
\text { water- } \\
\text { suface } \\
\text { model? }\end{array}$ \\
\hline \multicolumn{10}{|c|}{ Everglades National Park } \\
\hline A13 & 33 & Marsh & ENP & -1.51 & $25^{\circ} 29^{\prime} 50^{\prime \prime}$ & $80^{\circ} 42^{\prime} 45^{\prime \prime}$ & 528887.427 & 2820049.808 & Yes \\
\hline ANGEL & 34 & Marsh & SFWMD & -1.56 & $25^{\circ} 37^{\prime} 21.38^{\prime \prime}$ & $80^{\circ} 32^{\prime} 30.207^{\prime \prime}$ & 546009 & 2833971 & Yes \\
\hline $\begin{array}{l}\text { Bottle_Creek_at_- } \\
\text { Rookery_Branch }\end{array}$ & 35 & River & USGS & -1.51 & $25^{\circ} 28^{\prime} 04.72^{\prime \prime}$ & $80^{\circ} 51^{\prime} 16.30^{\prime \prime}$ & 514652.964 & 2816827.798 & No \\
\hline $\mathrm{CN}$ & 36 & River & ENP & -1.48 & $25^{\circ} 25^{\prime} 12^{\prime \prime}$ & $80^{\circ} 56^{\prime} 32^{\prime \prime}$ & 505785.445 & 2811458.529 & No \\
\hline $\mathrm{CP}$ & 37 & Marsh & ENP & -1.54 & $25^{\circ} 13^{\prime} 39^{\prime \prime}$ & $80^{\circ} 42^{\prime} 14^{\prime \prime}$ & 529818.807 & 2790185.111 & Yes \\
\hline CR2 & 38 & Marsh & ENP & -1.52 & $25^{\circ} 29^{\prime} 55^{\prime \prime}$ & $80^{\circ} 37^{\prime} 18^{\prime \prime}$ & 538016.057 & 2820226.398 & Yes \\
\hline CR3 & 39 & Marsh & ENP & -1.52 & $25^{\circ} 29^{\prime} 48^{\prime \prime}$ & $80^{\circ} 39^{\prime} 46^{\prime \prime}$ & 533884.832 & 2819999.994 & Yes \\
\hline CT27R & 40 & Marsh & ENP & -1.55 & $25^{\circ} 18^{\prime} 03^{\prime \prime}$ & $80^{\circ} 29^{\prime} 19^{\prime \prime}$ & 551472.277 & 2798370.432 & Yes \\
\hline CT50R & 41 & Marsh & ENP & -1.56 & $25^{\circ} 18^{\prime} 46^{\prime \prime}$ & $80^{\circ} 31^{\prime} 15^{\prime \prime}$ & 548223.823 & 2799681.092 & Yes \\
\hline CV5NR & 42 & Marsh & ENP & -1.55 & $25^{\circ} 18^{\prime} 08^{\prime \prime}$ & $80^{\circ} 29^{\prime} 15^{\prime \prime}$ & 551583.543 & 2798524.653 & Yes \\
\hline $\mathrm{CY} 2$ & 43 & Marsh & ENP & -1.51 & $25^{\circ} 19^{\prime} 39^{\prime \prime}$ & $80^{\circ} 40^{\prime} 58^{\prime \prime}$ & 531919.142 & 2801262.927 & Yes \\
\hline CY3 & 44 & Marsh & ENP & -1.51 & $25^{\circ} 19^{\prime} 40^{\prime \prime}$ & $80^{\circ} 45^{\prime} 02^{\prime \prime}$ & 525097.660 & 2801279.287 & Yes \\
\hline DO1 & 45 & Marsh & ENP & -1.51 & $25^{\circ} 22^{\prime} 19^{\prime \prime}$ & $80^{\circ} 41^{\prime} 27^{\prime \prime}$ & 531097.059 & 2806182.406 & Yes \\
\hline $\mathrm{DO} 2$ & 46 & Marsh & ENP & -1.51 & $25^{\circ} 23^{\prime} 18^{\prime \prime}$ & $80^{\circ} 44^{\prime} 39^{\prime \prime}$ & 525727.881 & 2807985.852 & Yes \\
\hline E112 & 47 & Marsh & ENP & -1.51 & $25^{\circ} 25^{\prime} 26^{\prime \prime}$ & $80^{\circ} 36^{\prime} 35^{\prime \prime}$ & 539240.685 & 2811955.633 & Yes \\
\hline E146 & 48 & Marsh & ENP & -1.54 & $25^{\circ} 15^{\prime} 09.20^{\prime \prime}$ & $80^{\circ} 39^{\prime} 58.54^{\prime \prime}$ & 533588.890 & 2793085.202 & Yes \\
\hline EDEN_3 & 49 & Marsh & USGS & -1.47 & $25^{\circ} 30^{\prime} 43.65^{\prime \prime}$ & $80^{\circ} 55^{\prime} 59.35^{\prime \prime}$ & 506727.069 & 2821669.040 & Yes \\
\hline EP1R & 50 & Marsh & ENP & -1.55 & $25^{\circ} 17^{\prime} 14.892^{\prime \prime}$ & $80^{\circ} 27^{\prime} 11.232^{\prime \prime}$ & 555056.9 & 2796891.8 & Yes \\
\hline EPSW & 51 & Marsh & ENP & -1.53 & $25^{\circ} 16^{\prime} 17^{\prime \prime}$ & $80^{\circ} 30^{\prime} 29^{\prime \prime}$ & 549526.788 & 2795102.691 & Yes \\
\hline EVER4 & 52 & Marsh & USGS & -1.57 & $25^{\circ} 20^{\prime} 19.5^{\prime \prime}$ & $80^{\circ} 32^{\prime} 48.0^{\prime \prime}$ & 545619.8 & 2802535.1 & Yes \\
\hline EVER5A & 53 & Marsh & USGS & -1.57 & $25^{\circ} 17^{\prime} 10^{\prime \prime}$ & $80^{\circ} 34^{\prime} 21.2^{\prime \prime}$ & 543033.1 & 2796697.6 & Yes \\
\hline EVER6 & 54 & Marsh & ENP & -1.54 & $25^{\circ} 17^{\prime} 49^{\prime \prime}$ & $80^{\circ} 30^{\prime} 41^{\prime \prime}$ & 549180.859 & 2797931.268 & Yes \\
\hline EVER7 & 55 & Marsh & ENP & -1.54 & $25^{\circ} 18^{\prime} 31^{\prime \prime}$ & $80^{\circ} 32^{\prime} 32^{\prime \prime}$ & 546072.444 & 2799212.195 & Yes \\
\hline EVER8 & 56 & Marsh & ENP & -1.54 & $25^{\circ} 20^{\prime} 42^{\prime \prime}$ & $80^{\circ} 28^{\prime} 42^{\prime \prime}$ & 552487.899 & 2803265.091 & Yes \\
\hline G-596 & 57 & Marsh & USGS & -1.55 & $25^{\circ} 38^{\prime} 16.8^{\prime \prime}$ & $80^{\circ} 30^{\prime} 43.1^{\prime \prime}$ & 548990 & 2835686 & Yes \\
\hline G-620 & 58 & Marsh & USGS & -1.51 & $25^{\circ} 39^{\prime} 22^{\prime \prime}$ & $80^{\circ} 45^{\prime} 59.2^{\prime \prime}$ & 523441.4 & 2837621.9 & Yes \\
\hline G-1251 & 59 & Marsh & USGS & -1.58 & $25^{\circ} 19^{\prime} 15.9^{\prime \prime}$ & $80^{\circ} 33^{\prime} 56.7^{\prime \prime}$ & 543705.7 & 2800572.4 & Yes \\
\hline G-1502 & 60 & Marsh & USGS & -1.56 & $25^{\circ} 36^{\prime} 56.6^{\prime \prime}$ & $80^{\circ} 34^{\prime} 58.6^{\prime \prime}$ & 541873.1 & 2833194.5 & No \\
\hline G-3272 & 61 & Marsh & USGS & -1.56 & $25^{\circ} 39^{\prime} 53.8^{\prime \prime}$ & $80^{\circ} 32^{\prime} 20.1^{\prime \prime}$ & 546274.5 & 2838660 & Yes \\
\hline G-3273 & 62 & Marsh & SFWMD & -1.56 & $25^{\circ} 37^{\prime} 49.381^{\prime \prime}$ & $80^{\circ} 34^{\prime} 33.21^{\prime \prime}$ & 542575.9 & 2834820.4 & Yes \\
\hline G-3437 & 63 & Marsh & USGS & -1.55 & $25^{\circ} 34^{\prime} 01.2^{\prime \prime}$ & $80^{\circ} 34^{\prime} 01.5^{\prime \prime}$ & 543483 & 2827804 & Yes \\
\hline G-3574 & 64 & Marsh & USGS & -1.55 & $25^{\circ} 44^{\prime} 46.9^{\prime \prime}$ & $80^{\circ} 29^{\prime} 52.4^{\prime \prime}$ & 550358 & 2847691 & Yes \\
\hline G-3575 & 65 & Marsh & USGS & -1.55 & $25^{\circ} 42^{\prime} 07.6^{\prime \prime}$ & $80^{\circ} 29^{\prime} 46.3^{\prime \prime}$ & 550547 & 2842792 & Yes \\
\hline G-3576 & 66 & Marsh & USGS & -1.55 & $25^{\circ} 44^{\prime} 45.0^{\prime \prime}$ & $80^{\circ} 30^{\prime} 51.3^{\prime \prime}$ & 548717 & 2847627 & Yes \\
\hline
\end{tabular}


Appendix 1. EDEN station, type of station, operating agency, vertical datum conversion, location, and water-surface model status sorted by area.-Continued

[EDEN, Everglades Depth Estimation Network; NWIS, National Water Information System; NGVD 1929, National Geodetic Vertical Datum of 1929; NAVD 1988, North American Vertical Datum of 1988; UTM, Universal Transverse Mercator; BCNP, Big Cypress National Preserve; ENP, Everglades National Park; SFWMD,

South Florida Water Management District; USGS, U.S. Geological Survey; ${ }^{\circ}$, degrees; ', minutes; ", seconds]

\begin{tabular}{|c|c|c|c|c|c|c|c|c|c|}
\hline $\begin{array}{l}\text { EDEN } \\
\text { station } \\
\text { name }\end{array}$ & $\begin{array}{c}\text { Index } \\
\text { number } \\
\text { (see } \\
\text { fig. 1) }\end{array}$ & $\begin{array}{l}\text { Type of } \\
\text { station } \\
\text { (physical } \\
\text { location of } \\
\text { station) }\end{array}$ & $\begin{array}{l}\text { Operating } \\
\text { agency }\end{array}$ & $\begin{array}{c}\text { Vertical } \\
\text { datum } \\
\text { conversion } \\
\text { (NGVD 1929 } \\
\text { to NAVD } \\
1988 \text { ) }\end{array}$ & Latitude & Longitude & $\begin{array}{c}\text { UTM } \\
\text { Easting, } \\
\text { in meters }\end{array}$ & $\begin{array}{c}\text { UTM } \\
\text { Northing, } \\
\text { in meters }\end{array}$ & $\begin{array}{c}\text { Gage } \\
\text { used in } \\
\text { water- } \\
\text { suface } \\
\text { model? }\end{array}$ \\
\hline \multicolumn{10}{|c|}{ Everglades National Park-Continued } \\
\hline G-3577 & 67 & Marsh & USGS & -1.55 & $25^{\circ} 42^{\prime} 09.4^{\prime \prime}$ & $80^{\circ} 30^{\prime} 02.0^{\prime \prime}$ & 550109 & 2842845 & Yes \\
\hline G-3578 & 68 & Marsh & USGS & -1.55 & $25^{\circ} 42^{\prime} 10^{\prime \prime}$ & $80^{\circ} 30^{\prime} 48^{\prime \prime}$ & 548827 & 2842859 & Yes \\
\hline G-3626 & 69 & Marsh & USGS & -1.55 & $25^{\circ} 37^{\prime} 06.93^{\prime \prime}$ & $80^{\circ} 30^{\prime} 40.58^{\prime \prime}$ & 549068 & 2833537 & Yes \\
\hline G-3628 & 70 & Marsh & USGS & -1.55 & $25^{\circ} 35^{\prime} 38.83^{\prime \prime}$ & $80^{\circ} 32^{\prime} 04.74^{\prime \prime}$ & 546730 & 2830818 & Yes \\
\hline Joe_Bay_2E & 71 & River & USGS & -1.54 & $25^{\circ} 13^{\prime} 57.45^{\prime \prime}$ & $80^{\circ} 31^{\prime} 29.52^{\prime \prime}$ & 547898.045 & 2790715.763 & Yes \\
\hline L31N_1 & 72 & Marsh & USGS & -1.56 & $25^{\circ} 44^{\prime} 46.8^{\prime \prime}$ & $80^{\circ} 29^{\prime} 51.5^{\prime \prime}$ & 550383 & 2847688.3 & No \\
\hline L31N_3 & 73 & Canal & USGS & -1.56 & $25^{\circ} 43^{\prime} 03.3^{\prime \prime}$ & $80^{\circ} 29^{\prime} 47.6^{\prime \prime}$ & 550503.8 & 2844504.8 & No \\
\hline L31NN & 74 & Marsh & SFWMD & -1.56 & $25^{\circ} 44^{\prime} 46.526^{\prime \prime}$ & $80^{\circ} 29^{\prime} 52.591^{\prime \prime}$ & 550352.7 & 2847679.7 & No \\
\hline L31W & 75 & Marsh & ENP & -1.51 & $25^{\circ} 26^{\prime} 13^{\prime \prime}$ & $80^{\circ} 35^{\prime} 23^{\prime \prime}$ & 541247.546 & 2813407.335 & Yes \\
\hline $\begin{array}{l}\text { McCormick_Creek_at_ } \\
\text { mouth }\end{array}$ & 76 & River & USGS & -1.52 & $25^{\circ} 10^{\prime} 05.50^{\prime \prime}$ & $80^{\circ} 44^{\prime} 00.92^{\prime \prime}$ & 527034.019 & 2783566.317 & Yes \\
\hline MO-214 & 77 & Marsh & USGS & -1.45 & $25^{\circ} 36^{\prime} 44.10^{\prime \prime}$ & $81^{\circ} 01^{\prime} 30.94^{\prime \prime}$ & 497463.68 & 2832744.37 & Yes \\
\hline MO-215 & 78 & Marsh & USGS & -1.52 & $25^{\circ} 28^{\prime} 20.65^{\prime \prime}$ & $80^{\circ} 50^{\prime} 53.59^{\prime \prime}$ & 515257.06 & 2817266.59 & Yes \\
\hline Mud_Creek_at_mouth & 79 & River & USGS & -1.54 & $25^{\circ} 12^{\prime} 11.89^{\prime \prime}$ & $80^{\circ} 35^{\prime} 02.80^{\prime \prime}$ & 541970.275 & 2787541.303 & Yes \\
\hline NCL & 80 & Marsh & ENP & -1.53 & $25^{\circ} 14^{\prime} 33^{\prime \prime}$ & $80^{\circ} 44^{\prime} 40^{\prime \prime}$ & 525730.637 & 2791837.675 & Yes \\
\hline NESRS1 & 81 & Marsh & USGS & -1.53 & $25^{\circ} 41^{\prime} 31^{\prime \prime}$ & $80^{\circ} 38^{\prime} 04^{\prime \prime}$ & 536672.917 & 2841631.531 & Yes \\
\hline NESRS2 & 82 & Marsh & USGS & -1.54 & $25^{\circ} 43^{\prime} 11^{\prime \prime}$ & $80^{\circ} 33^{\prime} 26^{\prime \prime}$ & 544745.076 & 2844886.160 & Yes \\
\hline NESRS4 & 83 & Marsh & USGS & -1.52 & $25^{\circ} 38^{\prime} 24^{\prime \prime}$ & $80^{\circ} 39^{\prime} 10^{\prime \prime}$ & 534848.007 & 2836028.273 & Yes \\
\hline NMP & 84 & Marsh & ENP & -1.52 & $25^{\circ} 15^{\prime} 13.86^{\prime \prime}$ & $80^{\circ} 47^{\prime} 53.268^{\prime \prime}$ & 520328.6 & 2793072 & Yes \\
\hline NP201 & 85 & Marsh & ENP & -1.51 & $25^{\circ} 43^{\prime} 00^{\prime \prime}$ & $80^{\circ} 43^{\prime} 10^{\prime \prime}$ & 528138.140 & 2844348.344 & Yes \\
\hline NP202 & 86 & Marsh & ENP & -1.51 & $25^{\circ} 39^{\prime} 43^{\prime \prime}$ & $80^{\circ} 42^{\prime} 31^{\prime \prime}$ & 529238.279 & 2838290.997 & Yes \\
\hline NP203 & 87 & Marsh & ENP & -1.51 & $25^{\circ} 37^{\prime} 22^{\prime \prime}$ & $80^{\circ} 44^{\prime} 19^{\prime \prime}$ & 526235.857 & 2833947.609 & Yes \\
\hline NP205 & 88 & Marsh & ENP & -1.5 & $25^{\circ} 41^{\prime} 19^{\prime \prime}$ & $80^{\circ} 50^{\prime} 52^{\prime \prime}$ & 515267.347 & 2841220.576 & Yes \\
\hline NP206 & 89 & Marsh & ENP & -1.53 & $25^{\circ} 32^{\prime} 39^{\prime \prime}$ & $80^{\circ} 40^{\prime} 19^{\prime \prime}$ & 532950.590 & 2825257.529 & Yes \\
\hline NP44 & 90 & Marsh & ENP & -1.49 & $25^{\circ} 26^{\prime} 00^{\prime \prime}$ & $80^{\circ} 43^{\prime} 13^{\prime \prime}$ & 528120.541 & 2812973.576 & Yes \\
\hline NP46 & 91 & Marsh & ENP & -1.51 & $25^{\circ} 19^{\prime} 06^{\prime \prime}$ & $80^{\circ} 47^{\prime} 45^{\prime \prime}$ & 520542.314 & 2800225.815 & Yes \\
\hline NP62 & 92 & Marsh & ENP & -1.51 & $25^{\circ} 26^{\prime} 18^{\prime \prime}$ & $80^{\circ} 46^{\prime} 58^{\prime \prime}$ & 521834.874 & 2813515.566 & Yes \\
\hline NP67 & 93 & Marsh & ENP & -1.51 & $25^{\circ} 19^{\prime} 46^{\prime \prime}$ & $80^{\circ} 39^{\prime} 01^{\prime \prime}$ & 535189.521 & 2801486.366 & Yes \\
\hline NP72 & 94 & Marsh & ENP & -1.55 & $25^{\circ} 23^{\prime} 41^{\prime \prime}$ & $80^{\circ} 42^{\prime} 11^{\prime \prime}$ & 529861.827 & 2808701.836 & Yes \\
\hline NTS1 & 95 & Marsh & ENP & -1.51 & $25^{\circ} 26^{\prime} 12^{\prime \prime}$ & $80^{\circ} 35^{\prime} 34^{\prime \prime}$ & 540940.391 & 2813375.636 & Yes \\
\hline NTS10 & 96 & Marsh & ENP & -1.51 & $25^{\circ} 27^{\prime} 37^{\prime \prime}$ & $80^{\circ} 36^{\prime} 18^{\prime \prime}$ & 539703.665 & 2815986.475 & Yes \\
\hline NTS14 & 97 & Marsh & ENP & -1.57 & $25^{\circ} 24^{\prime} 59^{\prime \prime}$ & $80^{\circ} 38^{\prime} 19^{\prime \prime}$ & 536337.725 & 2811116.973 & Yes \\
\hline NTS18 & 98 & Marsh & ENP & -1.55 & $25^{\circ} 29^{\prime} 02^{\prime \prime}$ & $80^{\circ} 33^{\prime} 59^{\prime \prime}$ & 543576.931 & 2818613.069 & Yes \\
\hline $\mathrm{OL}$ & 99 & Marsh & ENP & -1.51 & $25^{\circ} 15^{\prime} 49^{\prime \prime}$ & $80^{\circ} 36^{\prime} 47^{\prime \prime}$ & 538956.665 & 2794206.886 & Yes \\
\hline OT & 100 & Marsh & ENP & -1.5 & $25^{\circ} 34^{\prime} 43^{\prime \prime}$ & $80^{\circ} 57^{\prime} 52^{\prime \prime}$ & 503563.886 & 2829031.627 & Yes \\
\hline
\end{tabular}


Appendix 1. EDEN station, type of station, operating agency, vertical datum conversion, location, and water-surface model status sorted by area.-Continued

[EDEN, Everglades Depth Estimation Network; NWIS, National Water Information System; NGVD 1929, National Geodetic Vertical Datum of 1929; NAVD 1988, North American Vertical Datum of 1988; UTM, Universal Transverse Mercator; BCNP, Big Cypress National Preserve; ENP, Everglades National Park; SFWMD,

South Florida Water Management District; USGS, U.S. Geological Survey; ${ }^{\circ}$, degrees; ', minutes; ", seconds]

\begin{tabular}{|c|c|c|c|c|c|c|c|c|c|}
\hline $\begin{array}{c}\text { EDEN } \\
\text { station } \\
\text { name }\end{array}$ & $\begin{array}{c}\text { Index } \\
\text { number } \\
\text { (see } \\
\text { fig. 1) }\end{array}$ & $\begin{array}{l}\text { Type of } \\
\text { station } \\
\text { (physical } \\
\text { location of } \\
\text { station) }\end{array}$ & $\begin{array}{l}\text { Operating } \\
\text { agency }\end{array}$ & $\begin{array}{l}\text { Vertical } \\
\text { datum } \\
\text { conversion } \\
\text { (NGVD 1929 } \\
\text { to NAVD } \\
\text { 1988) }\end{array}$ & Latitude & Longitude & $\begin{array}{c}\text { UTM } \\
\text { Easting, } \\
\text { in meters }\end{array}$ & $\begin{array}{c}\text { UTM } \\
\text { Northing, } \\
\text { in meters }\end{array}$ & $\begin{array}{l}\text { Gage } \\
\text { used in } \\
\text { water- } \\
\text { suface } \\
\text { model? }\end{array}$ \\
\hline \multicolumn{10}{|c|}{ Everglades National Park-Continued } \\
\hline P33 & 101 & Marsh & ENP & -1.51 & $25^{\circ} 36^{\prime} 50^{\prime \prime}$ & $80^{\circ} 42^{\prime} 08^{\prime \prime}$ & 529891.454 & 2832970.997 & Yes \\
\hline P34 & 102 & Marsh & ENP & -1.5 & $25^{\circ} 36^{\prime} 27^{\prime \prime}$ & $80^{\circ} 56^{\prime} 27^{\prime \prime}$ & 505933.853 & 2832231.413 & Yes \\
\hline P35 & 103 & Marsh & ENP & -1.51 & $25^{\circ} 27^{\prime} 35^{\prime \prime}$ & $80^{\circ} 51^{\prime} 52^{\prime \prime}$ & 513620.732 & 2815873.190 & Yes \\
\hline P36 & 104 & Marsh & ENP & -1.51 & $25^{\circ} 31^{\prime} 38^{\prime \prime}$ & $80^{\circ} 47^{\prime} 44^{\prime \prime}$ & 520534.987 & 2823356.406 & Yes \\
\hline P37 & 105 & Marsh & ENP & -1.51 & $25^{\circ} 17^{\prime} 03^{\prime \prime}$ & $80^{\circ} 41^{\prime} 18^{\prime \prime}$ & 531371.135 & 2796463.309 & Yes \\
\hline P38 & 106 & Marsh & ENP & -1.51 & $25^{\circ} 22^{\prime} 10^{\prime \prime}$ & $80^{\circ} 50^{\prime} 00^{\prime \prime}$ & 516760.872 & 2805880.152 & Yes \\
\hline $\mathrm{R} 127$ & 107 & Marsh & ENP & -1.57 & $25^{\circ} 21^{\prime} 11^{\prime \prime}$ & $80^{\circ} 36^{\prime} 22^{\prime \prime}$ & 539626.907 & 2804113.177 & Yes \\
\hline $\mathrm{R} 3110$ & 108 & Marsh & ENP & -1.51 & $25^{\circ} 26^{\prime} 46^{\prime \prime}$ & $80^{\circ} 37^{\prime} 34^{\prime \prime}$ & 537585.658 & 2814411.647 & Yes \\
\hline RG1 & 109 & Marsh & ENP & -1.52 & $25^{\circ} 34^{\prime} 53^{\prime \prime}$ & $80^{\circ} 36^{\prime} 28^{\prime \prime}$ & 539384.903 & 2829396.758 & Yes \\
\hline RG2 & 110 & Marsh & ENP & -1.51 & $25^{\circ} 32^{\prime} 33^{\prime \prime}$ & $80^{\circ} 36^{\prime} 21^{\prime \prime}$ & 539592.961 & 2825090.995 & Yes \\
\hline RG3 & 111 & Marsh & ENP & -1.57 & $25^{\circ} 32^{\prime} 39.696^{\prime \prime}$ & $80^{\circ} 34^{\prime} 30.396^{\prime \prime}$ & 542685 & 2825294 & Yes \\
\hline S12A_T & 112 & Structure & USGS & -1.51 & $25^{\circ} 45^{\prime} 41^{\prime \prime}$ & $80^{\circ} 49^{\prime} 16^{\prime \prime}$ & 517941.198 & 2849281.230 & Yes \\
\hline S12B_T & 113 & Structure & USGS & -1.51 & $25^{\circ} 45^{\prime} 42^{\prime \prime}$ & $80^{\circ} 46^{\prime} 10^{\prime \prime}$ & 523113.304 & 2849299.590 & Yes \\
\hline $\mathrm{S} 12 \mathrm{C} \_\mathrm{T}$ & 114 & Structure & USGS & -1.51 & $25^{\circ} 45^{\prime} 42^{\prime \prime}$ & $80^{\circ} 43^{\prime} 37^{\prime \prime}$ & 527381.627 & 2849310.262 & Yes \\
\hline S12D_T & 115 & Structure & USGS & -1.52 & $25^{\circ} 45^{\prime} 42^{\prime \prime}$ & $80^{\circ} 40^{\prime} 55^{\prime \prime}$ & 531907.942 & 2849325.480 & Yes \\
\hline S175_H & 116 & Structure & SFWMD & -1.56 & $25^{\circ} 25^{\prime} 05^{\prime \prime}$ & $80^{\circ} 34^{\prime} 26^{\prime \prime}$ & 542862.358 & 2811294.509 & Yes \\
\hline S175_T & 117 & Structure & SFWMD & -1.56 & $25^{\circ} 25^{\prime} 03^{\prime \prime}$ & $80^{\circ} 34^{\prime} 26^{\prime \prime}$ & 542863.831 & 2811249.805 & No \\
\hline S18C_T & 118 & Structure & USGS & -1.56 & $25^{\circ} 19^{\prime} 49^{\prime \prime}$ & $80^{\circ} 31^{\prime} 31^{\prime \prime}$ & 547801.272 & 2800571.619 & Yes \\
\hline S332_T & 119 & Structure & SFWMD & -1.55 & $25^{\circ} 25^{\prime} 19^{\prime \prime}$ & $80^{\circ} 35^{\prime} 26^{\prime \prime}$ & 541180.000 & 2811722.300 & Yes \\
\hline SP & 120 & Marsh & ENP & -1.54 & $25^{\circ} 23^{\prime} 19^{\prime \prime}$ & $80^{\circ} 47^{\prime} 50^{\prime \prime}$ & 520390.779 & 2808007.486 & Yes \\
\hline SPARO & 121 & Marsh & ENP & -1.49 & $25^{\circ} 44^{\prime} 02.879^{\prime \prime}$ & $80^{\circ} 49^{\prime} 44.552^{\prime \prime}$ & 517147 & 2846252 & Yes \\
\hline SR1 & 122 & Marsh & ENP & -1.53 & $25^{\circ} 22^{\prime} 43.68^{\prime \prime}$ & $80^{\circ} 48^{\prime} 41.4^{\prime \prime}$ & 518962.769 & 2806906.174 & Yes \\
\hline Stillwater_Creek & 123 & River & USGS & -1.54 & $25^{\circ} 13^{\prime} 41.88^{\prime \prime}$ & $80^{\circ} 29^{\prime} 09.41^{\prime \prime}$ & 551726.651 & 2790343.280 & Yes \\
\hline $\begin{array}{l}\text { Taylor_River_at_ } \\
\text { mouth }\end{array}$ & 124 & River & USGS & -1.54 & $25^{\circ} 11^{\prime} 26.14^{\prime \prime}$ & $80^{\circ} 38^{\prime} 20.59^{\prime \prime}$ & 536376.844 & 2786171.796 & Yes \\
\hline TMC & 125 & Marsh & ENP & -1.49 & $25^{\circ} 36^{\prime} 50^{\prime \prime}$ & $80^{\circ} 52^{\prime} 20^{\prime \prime}$ & 512822.472 & 2832943.690 & Yes \\
\hline Trout_Creek_at_mouth & 126 & River & USGS & -1.54 & $25^{\circ} 12^{\prime} 53.66^{\prime \prime}$ & $80^{\circ} 32^{\prime} 00.61^{\prime \prime}$ & 547003.173 & 2788849.665 & Yes \\
\hline TSB & 127 & Structure & ENP & -1.51 & $25^{\circ} 24^{\prime} 10.7^{\prime \prime}$ & $80^{\circ} 36^{\prime} 26.3^{\prime \prime}$ & 539496.657 & 2809627.565 & Yes \\
\hline TSH & 128 & Marsh & ENP & -1.56 & $25^{\circ} 18^{\prime} 39^{\prime \prime}$ & $80^{\circ} 37^{\prime} 50^{\prime \prime}$ & 537180.091 & 2799430.863 & Yes \\
\hline $\begin{array}{l}\text { Upstream_Broad_ } \\
\text { River }\end{array}$ & 129 & River & USGS & -1.47 & $25^{\circ} 30^{\prime} 04.65^{\prime \prime}$ & $80^{\circ} 55^{\prime} 56^{\prime \prime}$ & 506811.425 & 2820460.213 & No \\
\hline $\begin{array}{l}\text { Upstream_Taylor_ } \\
\text { River }\end{array}$ & 130 & River & USGS & -1.54 & $25^{\circ} 12^{\prime} 37.07^{\prime \prime}$ & $80^{\circ} 38^{\prime} 51.60^{\prime \prime}$ & 535475.280 & 2788445.512 & Yes \\
\hline West_Highway_Creek & 131 & River & USGS & -1.54 & $25^{\circ} 14^{\prime} 31.59^{\prime \prime}$ & $80^{\circ} 26^{\prime} 51.26^{\prime \prime}$ & 555693.234 & 2791958.468 & Yes \\
\hline
\end{tabular}


Appendix 1. EDEN station, type of station, operating agency, vertical datum conversion, location, and water-surface model status sorted by area.-Continued

[EDEN, Everglades Depth Estimation Network; NWIS, National Water Information System; NGVD 1929, National Geodetic Vertical Datum of 1929; NAVD 1988, North American Vertical Datum of 1988; UTM, Universal Transverse Mercator; BCNP, Big Cypress National Preserve; ENP, Everglades National Park; SFWMD,

South Florida Water Management District; USGS, U.S. Geological Survey; ${ }^{\circ}$, degrees; ', minutes; ", seconds]

\begin{tabular}{|c|c|c|c|c|c|c|c|c|c|}
\hline $\begin{array}{c}\text { EDEN } \\
\text { station } \\
\text { name }\end{array}$ & $\begin{array}{c}\text { Index } \\
\text { number } \\
\text { (see } \\
\text { fig. 1) }\end{array}$ & $\begin{array}{l}\text { Type of } \\
\text { station } \\
\text { (physical } \\
\text { location of } \\
\text { station) }\end{array}$ & $\begin{array}{l}\text { Operating } \\
\text { agency }\end{array}$ & $\begin{array}{c}\text { Vertical } \\
\text { datum } \\
\text { conversion } \\
\text { (NGVD 1929 } \\
\text { to NAVD } \\
\text { 1988) }\end{array}$ & Latitude & Longitude & $\begin{array}{c}\text { UTM } \\
\text { Easting, } \\
\text { in meters }\end{array}$ & $\begin{array}{c}\text { UTM } \\
\text { Northing, } \\
\text { in meters }\end{array}$ & $\begin{array}{l}\text { Gage } \\
\text { used in } \\
\text { water- } \\
\text { suface } \\
\text { model? }\end{array}$ \\
\hline \multicolumn{10}{|c|}{ Pennsuco Wetlands } \\
\hline G119_H & 132 & Structure & SFWMD & -1.59 & $25^{\circ} 45^{\prime} 40^{\prime \prime}$ & $80^{\circ} 28^{\prime} 39^{\prime \prime}$ & 552405.366 & 2849342.856 & No \\
\hline G-975 & 133 & Marsh & USGS & -1.54 & $25^{\circ} 52^{\prime} 12.0^{\prime \prime}$ & $80^{\circ} 27^{\prime} 23.3^{\prime \prime}$ & 554455.233 & 2861399.992 & Yes \\
\hline G-1488 & 134 & Marsh & USGS & -1.55 & $25^{\circ} 49^{\prime} 06.7^{\prime \prime}$ & $80^{\circ} 28^{\prime} 56.4^{\prime \prime}$ & 551887 & 2855689 & Yes \\
\hline G-3567 & 135 & Marsh & USGS & -1.54 & $25^{\circ} 54^{\prime} 00.2^{\prime \prime}$ & $80^{\circ} 26^{\prime} 09.0^{\prime \prime}$ & 556509 & 2864737 & Yes \\
\hline G-3676 & 136 & Marsh & USGS & -1.57 & $25^{\circ} 47^{\prime} 15.5^{\prime \prime}$ & $80^{\circ} 25^{\prime} 25.9^{\prime \prime}$ & 557763 & 2852293 & Yes \\
\hline G-3761 & 137 & Marsh & USGS & -1.55 & $25^{\circ} 50^{\prime} 30.1^{\prime \prime}$ & $80^{\circ} 26^{\prime} 00.7^{\prime \prime}$ & 556768 & 2858275 & Yes \\
\hline G-3818 & 138 & Marsh & USGS & -1.54 & $25^{\circ} 50^{\prime} 36.8^{\prime \prime}$ & $80^{\circ} 27^{\prime} 04.3^{\prime \prime}$ & 554996.252 & 2858473.611 & Yes \\
\hline NWWF & 139 & Marsh & USGS & -1.54 & $25^{\circ} 53^{\prime} 28^{\prime \prime}$ & $80^{\circ} 25^{\prime} 13^{\prime \prime}$ & 558093.502 & 2863794.891 & No \\
\hline \multicolumn{10}{|c|}{ Water Conservation Area 1} \\
\hline G251_T & 140 & Marsh & SFWMD & -1.48 & $26^{\circ} 36^{\prime} 00.24^{\prime \prime}$ & $80^{\circ} 26^{\prime} 23.18^{\prime \prime}$ & 555695.902 & 2942262.398 & No \\
\hline G300_T & 141 & Structure & SFWMD & -1.48 & $26^{\circ} 40^{\prime} 37^{\prime \prime}$ & $80^{\circ} 21^{\prime} 48^{\prime \prime}$ & 563360.301 & 2950824.018 & Yes \\
\hline G301_T & 142 & Structure & SFWMD & -1.48 & $26^{\circ} 40^{\prime} 31^{\prime \prime}$ & $80^{\circ} 22^{\prime} 49^{\prime \prime}$ & 561649.234 & 2950621.874 & No \\
\hline G338_T & 143 & Marsh & SFWMD & -1.48 & $26^{\circ} 28^{\prime} 12.15^{\prime \prime}$ & $80^{\circ} 26^{\prime} 43.26^{\prime \prime}$ & 555285.814 & 2927858.866 & No \\
\hline NORTH_CA1 & 144 & Marsh & USGS & -1.44 & $26^{\circ} 35^{\prime} 38^{\prime \prime}$ & $80^{\circ} 21^{\prime} 13^{\prime \prime}$ & 564356.194 & 2941626.139 & Yes \\
\hline S10A_H & 145 & Structure & USGS & -1.49 & $26^{\circ} 21^{\prime} 36^{\prime \prime}$ & $80^{\circ} 18^{\prime} 45^{\prime \prime}$ & 568592.553 & 2915744.442 & Yes \\
\hline S10C_H & 146 & Structure & USGS & -1.47 & $26^{\circ} 22^{\prime} 18^{\prime \prime}$ & $80^{\circ} 21^{\prime} 09^{\prime \prime}$ & 564597.907 & 2917008.867 & Yes \\
\hline S10D_H & 147 & Structure & USGS & -1.46 & $26^{\circ} 23^{\prime} 19^{\prime \prime}$ & $80^{\circ} 22^{\prime} 54^{\prime \prime}$ & 561683.299 & 2918858.313 & Yes \\
\hline S39_H & 148 & Structure & SFWMD & -1.54 & $26^{\circ} 21^{\prime} 21^{\prime \prime}$ & $80^{\circ} 17^{\prime} 53^{\prime \prime}$ & 570050.073 & 2915284.569 & Yes \\
\hline SITE_7 & 149 & Marsh & USGS & -1.46 & $26^{\circ} 31^{\prime} 11^{\prime \prime}$ & $80^{\circ} 20^{\prime} 49^{\prime \prime}$ & 565061.878 & 2933415.386 & Yes \\
\hline SITE_8C & 150 & Marsh & USGS & -1.47 & $26^{\circ} 29^{\prime} 57.4^{\prime \prime}$ & $80^{\circ} 13^{\prime} 19.6^{\prime \prime}$ & 577474.798 & 2931309.203 & Yes \\
\hline SITE_8T & 151 & Marsh & USGS & -1.47 & $26^{\circ} 29^{\prime} 59^{\prime \prime}$ & $80^{\circ} 14^{\prime} 05^{\prime \prime}$ & 576266.93 & 2931241.7 & Yes \\
\hline SITE_9 & 152 & Marsh & USGS & -1.48 & $26^{\circ} 27^{\prime} 35.3^{\prime \prime}$ & $80^{\circ} 17^{\prime} 25.9^{\prime \prime}$ & 570077.533 & 2927288.801 & Yes \\
\hline SOUTH_CA1 & 153 & Marsh & USGS & -1.48 & $26^{\circ} 25^{\prime} 17.0^{\prime \prime}$ & $80^{\circ} 20^{\prime} 16.3^{\prime \prime}$ & 565752.408 & 2922897.266 & Yes \\
\hline \multicolumn{10}{|c|}{ Water Conservation Area 2A } \\
\hline EDEN_11 & 154 & Marsh & USGS & -1.45 & $26^{\circ} 22^{\prime} 35^{\prime \prime}$ & $80^{\circ} 27^{\prime} 19^{\prime \prime}$ & 553893.796 & 2918188.099 & Yes \\
\hline G339_H & 155 & Structure & SFWMD & -1.48 & $26^{\circ} 27^{\prime} 48^{\prime \prime}$ & $80^{\circ} 27^{\prime} 09^{\prime \prime}$ & 554571.678 & 2927121.843 & Yes \\
\hline G339_T & 156 & Structure & SFWMD & -1.48 & $26^{\circ} 27^{\prime} 48^{\prime \prime}$ & $80^{\circ} 27^{\prime} 10^{\prime \prime}$ & 554557.919 & 2927098.969 & Yes \\
\hline S10A_T & 157 & Structure & USGS & -1.49 & $26^{\circ} 21^{\prime} 33^{\prime \prime}$ & $80^{\circ} 18^{\prime} 46^{\prime \prime}$ & 568563.448 & 2915633.120 & Yes \\
\hline S10C_T & 158 & Structure & USGS & -1.47 & $26^{\circ} 22^{\prime} 16^{\prime \prime}$ & $80^{\circ} 21^{\prime} 09^{\prime \prime}$ & 564583.856 & 2916947.986 & Yes \\
\hline S10D_T & 159 & Structure & USGS & -1.46 & $26^{\circ} 23^{\prime} 18^{\prime \prime}$ & $80^{\circ} 22^{\prime} 55^{\prime \prime}$ & 561635.814 & 2918827.896 & Yes \\
\hline S11A_H & 160 & Structure & USGS & -1.48 & $26^{\circ} 10^{\prime} 37^{\prime \prime}$ & $80^{\circ} 26^{\prime} 54^{\prime \prime}$ & 555115.461 & 2895405.335 & Yes \\
\hline S11B_H & 161 & Structure & USGS & -1.48 & $26^{\circ} 12^{\prime} 09^{\prime \prime}$ & $80^{\circ} 27^{\prime} 14^{\prime \prime}$ & 554557.922 & 2898235.154 & Yes \\
\hline S11C_H & 162 & Structure & USGS & -1.48 & $26^{\circ} 13^{\prime} 47^{\prime \prime}$ & $80^{\circ} 27^{\prime} 35^{\prime \prime}$ & 553950.857 & 2901225.214 & Yes \\
\hline S144_H & 163 & Structure & SFWMD & -1.48 & $26^{\circ} 13^{\prime} 06^{\prime \prime}$ & $80^{\circ} 23^{\prime} 52^{\prime \prime}$ & 560158.677 & 2900008.912 & Yes \\
\hline S145_H & 164 & Structure & SFWMD & -1.48 & $26^{\circ} 13^{\prime} 19^{\prime \prime}$ & $80^{\circ} 21^{\prime} 57^{\prime \prime}$ & 563348.909 & 2900416.901 & Yes \\
\hline
\end{tabular}


Appendix 1. EDEN station, type of station, operating agency, vertical datum conversion, location, and water-surface model status sorted by area.-Continued

[EDEN, Everglades Depth Estimation Network; NWIS, National Water Information System; NGVD 1929, National Geodetic Vertical Datum of 1929; NAVD 1988, North American Vertical Datum of 1988; UTM, Universal Transverse Mercator; BCNP, Big Cypress National Preserve; ENP, Everglades National Park; SFWMD,

South Florida Water Management District; USGS, U.S. Geological Survey; ’, degrees; ', minutes; ", seconds]

\begin{tabular}{|c|c|c|c|c|c|c|c|c|c|}
\hline $\begin{array}{c}\text { EDEN } \\
\text { station } \\
\text { name }\end{array}$ & $\begin{array}{c}\text { Index } \\
\text { number } \\
\text { (see } \\
\text { fig. 1) }\end{array}$ & $\begin{array}{l}\text { Type of } \\
\text { station } \\
\text { (physical } \\
\text { location of } \\
\text { station) }\end{array}$ & $\begin{array}{c}\text { Operating } \\
\text { agency }\end{array}$ & $\begin{array}{c}\text { Vertical } \\
\text { datum } \\
\text { conversion } \\
\text { (NGVD } 1929 \\
\text { to NAVD } \\
\text { 1988) }\end{array}$ & Latitude & Longitude & $\begin{array}{c}\text { UTM } \\
\text { Easting, } \\
\text { in meters }\end{array}$ & $\begin{array}{c}\text { UTM } \\
\text { Northing, } \\
\text { in meters }\end{array}$ & $\begin{array}{c}\text { Gage } \\
\text { used in } \\
\text { water- } \\
\text { suface } \\
\text { model? }\end{array}$ \\
\hline \multicolumn{10}{|c|}{ Water Conservation Area 2A-Continued } \\
\hline S146_H & 165 & Structure & SFWMD & -1.48 & $26^{\circ} 13^{\prime} 32^{\prime \prime}$ & $80^{\circ} 20^{\prime} 01^{\prime \prime}$ & 566576.243 & 2900838.887 & Yes \\
\hline S7_T & 166 & Structure & SFWMD & -1.46 & $26^{\circ} 20^{\prime} 07^{\prime \prime}$ & $80^{\circ} 32^{\prime} 12^{\prime \prime}$ & 546248.382 & 2912887.485 & Yes \\
\hline SITE_17 & 167 & Marsh & USGS & -1.49 & $26^{\circ} 17^{\prime} 12^{\prime \prime}$ & $80^{\circ} 24^{\prime} 39^{\prime \prime}$ & 558813.967 & 2907573.828 & Yes \\
\hline SITE_19 & 168 & Marsh & USGS & -1.47 & $26^{\circ} 16^{\prime} 53.3^{\prime \prime}$ & $80^{\circ} 18^{\prime} 23.9^{\prime \prime}$ & 569272.038 & 2907133.427 & Yes \\
\hline WC2AN1 & 169 & Marsh & SFWMD & -1.46 & $26^{\circ} 26^{\prime} 51.93^{\prime \prime}$ & $80^{\circ} 27^{\prime} 21.92^{\prime \prime}$ & 554225.819 & 2925386.420 & Yes \\
\hline WC2AS1 & 170 & Marsh & SFWMD & -1.46 & $26^{\circ} 23^{\prime} 24.81^{\prime \prime}$ & $80^{\circ} 29^{\prime} 33.08^{\prime \prime}$ & 550618.602 & 2918999.539 & Yes \\
\hline WCA2E4 & 171 & Marsh & SFWMD & -1.56 & $26^{\circ} 18^{\prime} 35^{\prime \prime}$ & $80^{\circ} 21^{\prime} 23^{\prime \prime}$ & 564236.973 & 2910153.081 & Yes \\
\hline WCA2F1 & 172 & Marsh & SFWMD & -1.54 & $26^{\circ} 21^{\prime} 36^{\prime \prime}$ & $80^{\circ} 22^{\prime} 11^{\prime \prime}$ & 562878.889 & 2915714.735 & Yes \\
\hline WCA2F4 & 173 & Marsh & SFWMD & -1.55 & $26^{\circ} 19^{\prime} 02^{\prime \prime}$ & $80^{\circ} 23^{\prime} 05^{\prime \prime}$ & 561404.793 & 2910969.930 & Yes \\
\hline WCA2U1 & 174 & Marsh & SFWMD & -1.5 & $26^{\circ} 14^{\prime} 29^{\prime \prime}$ & $80^{\circ} 21^{\prime} 21^{\prime \prime}$ & 564330.063 & 2902585.567 & Yes \\
\hline \multicolumn{10}{|c|}{ Water Conservation Area 2B } \\
\hline EDEN_13 & 175 & Marsh & USGS & -1.53 & $26^{\circ} 10^{\prime} 35^{\prime \prime}$ & $80^{\circ} 22^{\prime} 17^{\prime \prime}$ & 562816.463 & 2895370.047 & Yes \\
\hline S141_H & 176 & Structure & SFWMD & -1.57 & $26^{\circ} 09^{\prime} 02^{\prime \prime}$ & $80^{\circ} 26^{\prime} 32^{\prime \prime}$ & 555755.440 & 2892486.864 & Yes \\
\hline $\mathrm{S} 141+\mathrm{T}$ & 177 & Structure & SFWMD & -1.57 & $26^{\circ} 09^{\prime} 03^{\prime \prime}$ & $80^{\circ} 26^{\prime} 33^{\prime \prime}$ & 555712.990 & 2892496.306 & Yes \\
\hline $\mathrm{S} 142 \_\mathrm{T}$ & 178 & Structure & SFWMD & -1.48 & $26^{\circ} 09^{\prime} 37^{\prime \prime}$ & $80^{\circ} 26^{\prime} 41^{\prime \prime}$ & 555489.713 & 2893542.979 & Yes \\
\hline $\mathrm{S} 143$ T & 179 & Structure & SFWMD & -1.49 & $26^{\circ} 10^{\prime} 34^{\prime \prime}$ & $80^{\circ} 26^{\prime} 54^{\prime \prime}$ & 555136.925 & 2895305.445 & Yes \\
\hline S144_T & 180 & Structure & SFWMD & -1.48 & $26^{\circ} 13^{\prime} 05^{\prime \prime}$ & $80^{\circ} 23^{\prime} 52^{\prime \prime}$ & 560164.601 & 2899975.541 & Yes \\
\hline $\mathrm{S} 145$ T & 181 & Structure & SFWMD & -1.48 & $26^{\circ} 13^{\prime} 18^{\prime \prime}$ & $80^{\circ} 21^{\prime} 57^{\prime \prime}$ & 563352.073 & 2900385.748 & Yes \\
\hline S146_T & 182 & Structure & SFWMD & -1.48 & $26^{\circ} 13^{\prime} 31^{\prime \prime}$ & $80^{\circ} 20^{\prime} 00^{\prime \prime}$ & 566581.413 & 2900799.442 & Yes \\
\hline S34_H & 183 & Structure & SFWMD & -1.5 & $26^{\circ} 09^{\prime} 02^{\prime \prime}$ & $80^{\circ} 26^{\prime} 33^{\prime \prime}$ & 555714.500 & 2892479.605 & Yes \\
\hline SITE_99 & 184 & Marsh & USGS & -1.54 & $26^{\circ} 08^{\prime} 11.2^{\prime \prime}$ & $80^{\circ} 22^{\prime} 01.5^{\prime \prime}$ & 563276.527 & 2891044.000 & Yes \\
\hline \multicolumn{10}{|c|}{ Water Conservation Area 3A } \\
\hline $3 \mathrm{~A} 10$ & 185 & Marsh & SFWMD & -1.45 & $26^{\circ} 16^{\prime} 46^{\prime \prime}$ & $80^{\circ} 44^{\prime} 23^{\prime \prime}$ & 525980.050 & 2906666.287 & Yes \\
\hline 3A11 & 186 & Marsh & SFWMD & -1.45 & $26^{\circ} 13^{\prime} 06^{\prime \prime}$ & $80^{\circ} 44^{\prime} 37^{\prime \prime}$ & 525605.142 & 2899897.817 & Yes \\
\hline $3 \mathrm{~A} 12$ & 187 & Marsh & SFWMD & -1.46 & $26^{\circ} 10^{\prime} 09^{\prime \prime}$ & $80^{\circ} 40^{\prime} 32^{\prime \prime}$ & 532417.152 & 2894468.134 & Yes \\
\hline 3AN1W1 & 188 & Marsh & SFWMD & -1.45 & $26^{\circ} 11^{\prime} 17^{\prime \prime}$ & $80^{\circ} 44^{\prime} 24^{\prime \prime}$ & 525972.578 & 2896545.474 & Yes \\
\hline $3 \mathrm{ANE}$ & 189 & Marsh & SFWMD & -1.46 & $26^{\circ} 16^{\prime} 44^{\prime \prime}$ & $80^{\circ} 36^{\prime} 17^{\prime \prime}$ & 539459.069 & 2906638.870 & No \\
\hline 3ANE_GW & 190 & Marsh & SFWMD & -1.46 & $26^{\circ} 16^{\prime} 44^{\prime \prime}$ & $80^{\circ} 36^{\prime} 17^{\prime \prime}$ & 539459.069 & 2906638.870 & Yes \\
\hline $3 \mathrm{ANW}$ & 191 & Marsh & SFWMD & -1.4 & $26^{\circ} 16^{\prime} 00^{\prime \prime}$ & $80^{\circ} 46^{\prime} 49^{\prime \prime}$ & 521937.212 & 2905238.337 & No \\
\hline 3ANW_GW & 192 & Marsh & SFWMD & -1.4 & $26^{\circ} 16^{\prime} 00^{\prime \prime}$ & $80^{\circ} 46^{\prime} 49^{\prime \prime}$ & 521937.212 & 2905238.337 & Yes \\
\hline $3 \mathrm{AS}$ & 193 & Marsh & SFWMD & -1.47 & $26^{\circ} 04^{\prime} 55.534^{\prime \prime}$ & $80^{\circ} 41^{\prime} 29.551^{\prime \prime}$ & 531579.539 & 2884991.384 & Yes \\
\hline $3 \mathrm{AS} 3 \mathrm{~W} 1$ & 194 & Marsh & SFWMD & -1.5 & $25^{\circ} 51^{\prime} 27^{\prime \prime}$ & $80^{\circ} 46^{\prime} 15^{\prime \prime}$ & 522955.752 & 2859933.841 & Yes \\
\hline $3 \mathrm{ASW}$ & 195 & Marsh & SFWMD & -1.47 & $25^{\circ} 59^{\prime} 24^{\prime \prime}$ & $80^{\circ} 50^{\prime} 09^{\prime \prime}$ & 516424.379 & 2874596.982 & Yes \\
\hline EDEN_12 & 196 & Marsh & USGS & -1.49 & $26^{\circ} 00^{\prime} 42^{\prime \prime}$ & $80^{\circ} 35^{\prime} 17^{\prime \prime}$ & 541222.586 & 2877040.840 & Yes \\
\hline EDEN_14 & 197 & Marsh & USGS & -1.47 & $26^{\circ} 04^{\prime} 10^{\prime \prime}$ & $80^{\circ} 45^{\prime} 27^{\prime \prime}$ & 524254.593 & 2883396.965 & Yes \\
\hline
\end{tabular}


Appendix 1. EDEN station, type of station, operating agency, vertical datum conversion, location, and water-surface model status sorted by area.-Continued

[EDEN, Everglades Depth Estimation Network; NWIS, National Water Information System; NGVD 1929, National Geodetic Vertical Datum of 1929; NAVD 1988, North American Vertical Datum of 1988; UTM, Universal Transverse Mercator; BCNP, Big Cypress National Preserve; ENP, Everglades National Park; SFWMD, South Florida Water Management District; USGS, U.S. Geological Survey; , degrees; ', minutes; ", seconds]

\begin{tabular}{|c|c|c|c|c|c|c|c|c|c|}
\hline $\begin{array}{c}\text { EDEN } \\
\text { station } \\
\text { name }\end{array}$ & $\begin{array}{c}\text { Index } \\
\text { number } \\
\text { (see } \\
\text { fig. 1) }\end{array}$ & $\begin{array}{l}\text { Type of } \\
\text { station } \\
\text { (physical } \\
\text { location of } \\
\text { station) }\end{array}$ & $\begin{array}{c}\text { Operating } \\
\text { agency }\end{array}$ & $\begin{array}{l}\text { Vertical } \\
\text { datum } \\
\text { conversion } \\
\text { (NGVD 1929 } \\
\text { to NAVD } \\
1988 \text { ) }\end{array}$ & Latitude & Longitude & $\begin{array}{c}\text { UTM } \\
\text { Easting, } \\
\text { in meters }\end{array}$ & $\begin{array}{c}\text { UTM } \\
\text { Northing, } \\
\text { in meters }\end{array}$ & $\begin{array}{c}\text { Gage } \\
\text { used in } \\
\text { water- } \\
\text { suface } \\
\text { model? }\end{array}$ \\
\hline \multicolumn{10}{|c|}{ Water Conservation Area 3A-Continued } \\
\hline EDEN_4 & 198 & Marsh & USGS & -1.48 & $26^{\circ} 05^{\prime} 36^{\prime \prime}$ & $80^{\circ} 30^{\prime} 25^{\prime \prime}$ & 549305.169 & 2886113.293 & Yes \\
\hline EDEN_5 & 199 & Marsh & USGS & -1.46 & $26^{\circ} 07^{\prime} 25^{\prime \prime}$ & $80^{\circ} 45^{\prime} 10^{\prime \prime}$ & 524715.520 & 2889396.583 & Yes \\
\hline EDEN_8 & 200 & Marsh & USGS & -1.51 & $25^{\circ} 52^{\prime} 00^{\prime \prime}$ & $80^{\circ} 40^{\prime} 50^{\prime \prime}$ & 532005.360 & 2860957.077 & Yes \\
\hline EDEN_9 & 201 & Marsh & USGS & -1.46 & $26^{\circ} 13^{\prime} 19^{\prime \prime}$ & $80^{\circ} 35^{\prime} 32^{\prime \prime}$ & 540732.670 & 2900327.206 & Yes \\
\hline L28S1 & 202 & Marsh & SFWMD & -1.46 & $26^{\circ} 05^{\prime} 38^{\prime \prime}$ & $80^{\circ} 50^{\prime} 34^{\prime \prime}$ & 515715.505 & 2886100.826 & Yes \\
\hline L28S2 & 203 & Marsh & SFWMD & -1.46 & $26^{\circ} 05^{\prime} 38^{\prime \prime}$ & $80^{\circ} 50^{\prime} 05^{\prime \prime}$ & 516521.067 & 2886101.819 & Yes \\
\hline S11A_T & 204 & Structure & USGS & -1.48 & $26^{\circ} 10^{\prime} 37^{\prime \prime}$ & $80^{\circ} 26^{\prime} 57^{\prime \prime}$ & 555030.782 & 2895390.867 & Yes \\
\hline S11B_T & 205 & Structure & USGS & -1.48 & $26^{\circ} 12^{\prime} 09^{\prime \prime}$ & $80^{\circ} 27^{\prime} 18^{\prime \prime}$ & 554456.545 & 2898221.280 & Yes \\
\hline S11C_T & 206 & Structure & USGS & -1.48 & $26^{\circ} 13^{\prime} 46^{\prime \prime}$ & $80^{\circ} 27^{\prime} 39^{\prime \prime}$ & 553853.047 & 2901210.422 & Yes \\
\hline S12A_H & 207 & Structure & USGS & -1.51 & $25^{\circ} 45^{\prime} 44^{\prime \prime}$ & $80^{\circ} 49^{\prime} 16^{\prime \prime}$ & 517940.034 & 2849363.574 & Yes \\
\hline S12B_H & 208 & Structure & USGS & -1.51 & $25^{\circ} 45^{\prime} 44^{\prime \prime}$ & $80^{\circ} 46^{\prime} 10^{\prime \prime}$ & 523115.619 & 2849372.194 & Yes \\
\hline $\mathrm{S} 12 \mathrm{C} \_\mathrm{H}$ & 209 & Structure & USGS & -1.51 & $25^{\circ} 45^{\prime} 44^{\prime \prime}$ & $80^{\circ} 43^{\prime} 37^{\prime \prime}$ & 527382.653 & 2849386.199 & Yes \\
\hline S12D_H & 210 & Structure & USGS & -1.52 & $25^{\circ} 45^{\prime} 44^{\prime \prime}$ & $80^{\circ} 40^{\prime} 54^{\prime \prime}$ & 531912.896 & 2849401.658 & Yes \\
\hline S140_H & 211 & Structure & SFWMD & -1.45 & $26^{\circ} 10^{\prime} 18^{\prime \prime}$ & $80^{\circ} 49^{\prime} 40^{\prime \prime}$ & 517207.404 & 2894700.008 & Yes \\
\hline S140_T & 212 & Structure & SFWMD & -1.45 & $26^{\circ} 10^{\prime} 18^{\prime \prime}$ & $80^{\circ} 49^{\prime} 38^{\prime \prime}$ & 517275.034 & 2894702.874 & Yes \\
\hline S142_H & 213 & Structure & SFWMD & -1.48 & $26^{\circ} 09^{\prime} 36^{\prime \prime}$ & $80^{\circ} 26^{\prime} 47^{\prime \prime}$ & 555326.925 & 2893522.651 & Yes \\
\hline $\mathrm{S} 150 \_\mathrm{T}$ & 214 & Structure & SFWMD & -1.46 & $26^{\circ} 20^{\prime} 05^{\prime \prime}$ & $80^{\circ} 32^{\prime} 22^{\prime \prime}$ & 545964.122 & 2912820.628 & Yes \\
\hline S151_H & 215 & Structure & SFWMD & -1.54 & $26^{\circ} 00^{\prime} 42^{\prime \prime}$ & $80^{\circ} 30^{\prime} 36^{\prime \prime}$ & 549024.275 & 2877054.845 & Yes \\
\hline S333_H & 216 & Structure & SFWMD & -1.54 & $25^{\circ} 45^{\prime} 43^{\prime \prime}$ & $80^{\circ} 40^{\prime} 27^{\prime \prime}$ & 532668.149 & 2849372.816 & Yes \\
\hline S339_H & 217 & Structure & SFWMD & -1.45 & $26^{\circ} 13^{\prime} 04^{\prime \prime}$ & $80^{\circ} 41^{\prime} 27^{\prime \prime}$ & 530880.379 & 2899828.623 & No \\
\hline S339_T & 218 & Structure & SFWMD & -1.45 & $26^{\circ} 13^{\prime} 01^{\prime \prime}$ & $80^{\circ} 41^{\prime} 25^{\prime \prime}$ & 530927.838 & 2899756.023 & No \\
\hline S340_H & 219 & Structure & SFWMD & -1.34 & $26^{\circ} 07^{\prime} 09^{\prime \prime}$ & $80^{\circ} 36^{\prime} 48^{\prime \prime}$ & 538669.804 & 2888945.872 & No \\
\hline S340_T & 220 & Structure & SFWMD & -1.34 & $26^{\circ} 07^{\prime} 06^{\prime \prime}$ & $80^{\circ} 36^{\prime} 45^{\prime \prime}$ & 538735.436 & 2888851.650 & No \\
\hline S343A_H & 221 & Structure & SFWMD & -1.54 & $25^{\circ} 47^{\prime} 21^{\prime \prime}$ & $80^{\circ} 51^{\prime} 19^{\prime \prime}$ & 514522.218 & 2852358.686 & Yes \\
\hline S343B_H & 222 & Structure & SFWMD & -1.53 & $25^{\circ} 46^{\prime} 42^{\prime \prime}$ & $80^{\circ} 50^{\prime} 38^{\prime \prime}$ & 515652.049 & 2851135.295 & Yes \\
\hline S344_H & 223 & Structure & SFWMD & -1.47 & $25^{\circ} 55^{\prime} 08^{\prime \prime}$ & $80^{\circ} 50^{\prime} 11^{\prime \prime}$ & 516395.177 & 2866714.379 & Yes \\
\hline SITE_62 & 224 & Marsh & USGS & -1.46 & $26^{\circ} 10^{\prime} 29^{\prime \prime}$ & $80^{\circ} 45^{\prime} 04^{\prime \prime}$ & 524865.169 & 2895066.730 & Yes \\
\hline SITE_63 & 225 & Marsh & USGS & -1.47 & $26^{\circ} 11^{\prime} 20^{\prime \prime}$ & $80^{\circ} 31^{\prime} 51^{\prime \prime}$ & 546872.501 & 2896696.403 & Yes \\
\hline SITE_64 & 226 & Marsh & USGS & -1.52 & $25^{\circ} 58^{\prime} 32^{\prime \prime}$ & $80^{\circ} 40^{\prime} 09^{\prime \prime}$ & 533109.962 & 2873028.913 & Yes \\
\hline SITE_65 & 227 & Marsh & USGS & -1.58 & $25^{\circ} 48^{\prime} 50.0^{\prime \prime}$ & $80^{\circ} 43^{\prime} 11.4^{\prime \prime}$ & 528087.229 & 2855206.635 & Yes \\
\hline SITE_69W & 228 & Marsh & USGS & -1.52 & $25^{\circ} 54^{\prime} 24.7^{\prime \prime}$ & $80^{\circ} 35^{\prime} 21.1^{\prime \prime}$ & 541144.94 & 2865433.8 & Yes \\
\hline $\mathrm{USSO}_{-} \mathrm{O}^{1}$ & 229 & Structure & SFWMD & -1.42 & $26^{\circ} 19^{\prime} 48.302^{\prime \prime}$ & $80^{\circ} 52^{\prime} 55.228^{\prime \prime}$ & 511775 & 2912245 & No \\
\hline W2 & 230 & Marsh & USGS & -1.5 & $25^{\circ} 47^{\prime} 59^{\prime \prime}$ & $80^{\circ} 48^{\prime} 32^{\prime \prime}$ & 519158.290 & 2853518.554 & Yes \\
\hline W11 & 231 & Marsh & USGS & -1.49 & $25^{\circ} 56^{\prime} 34^{\prime \prime}$ & $80^{\circ} 45^{\prime} 00^{\prime \prime}$ & 525031.575 & 2869370.755 & Yes \\
\hline W18 & 232 & Marsh & USGS & -1.47 & $26^{\circ} 00^{\prime} 07^{\prime \prime}$ & $80^{\circ} 46^{\prime} 44^{\prime \prime}$ & 522127.954 & 2875917.892 & Yes \\
\hline
\end{tabular}


Appendix 1. EDEN station, type of station, operating agency, vertical datum conversion, location, and water-surface model status sorted by area.-Continued

[EDEN, Everglades Depth Estimation Network; NWIS, National Water Information System; NGVD 1929, National Geodetic Vertical Datum of 1929; NAVD 1988, North American Vertical Datum of 1988; UTM, Universal Transverse Mercator; BCNP, Big Cypress National Preserve; ENP, Everglades National Park; SFWMD, South Florida Water Management District; USGS, U.S. Geological Survey; ’, degrees; ', minutes; ", seconds]

\begin{tabular}{|c|c|c|c|c|c|c|c|c|c|}
\hline $\begin{array}{c}\text { EDEN } \\
\text { station } \\
\text { name }\end{array}$ & $\begin{array}{c}\text { Index } \\
\text { number } \\
\text { (see } \\
\text { fig. 1) }\end{array}$ & $\begin{array}{l}\text { Type of } \\
\text { station } \\
\text { (physical } \\
\text { location of } \\
\text { station) }\end{array}$ & $\begin{array}{l}\text { Operating } \\
\text { agency }\end{array}$ & $\begin{array}{c}\text { Vertical } \\
\text { datum } \\
\text { conversion } \\
\text { (NGVD 1929 } \\
\text { to NAVD } \\
1988 \text { ) } \\
\end{array}$ & Latitude & Longitude & $\begin{array}{c}\text { UTM } \\
\text { Easting, } \\
\text { in meters }\end{array}$ & $\begin{array}{c}\text { UTM } \\
\text { Northing, } \\
\text { in meters }\end{array}$ & $\begin{array}{c}\text { Gage } \\
\text { used in } \\
\text { water- } \\
\text { suface } \\
\text { model? }\end{array}$ \\
\hline \multicolumn{10}{|c|}{ Water Conservation Area 3B } \\
\hline 3BS1W1 & 233 & Marsh & SFWMD & -1.55 & $25^{\circ} 46^{\prime} 50^{\prime \prime}$ & $80^{\circ} 30^{\prime} 40^{\prime \prime}$ & 549012.054 & 2851484.116 & Yes \\
\hline 3B-SE & 234 & Marsh & SFWMD & -1.56 & $25^{\circ} 47^{\prime} 17^{\prime \prime}$ & $80^{\circ} 29^{\prime} 58^{\prime \prime}$ & 550178.692 & 2852319.048 & Yes \\
\hline EDEN_7 & 235 & Marsh & USGS & -1.52 & $25^{\circ} 57^{\prime} 08^{\prime \prime}$ & $80^{\circ} 29^{\prime} 55^{\prime \prime}$ & 550198.509 & 2870488.890 & Yes \\
\hline EDEN_10 & 236 & Marsh & USGS & -1.54 & $25^{\circ} 47^{\prime} 07^{\prime \prime}$ & $80^{\circ} 37^{\prime} 02^{\prime \prime}$ & 538377.058 & 2851960.827 & Yes \\
\hline S333_T & 237 & Structure & SFWMD & -1.54 & $25^{\circ} 45^{\prime} 42^{\prime \prime}$ & $80^{\circ} 40^{\prime} 23^{\prime \prime}$ & 532774.073 & 2849335.350 & Yes \\
\hline S334_H & 238 & Structure & SFWMD & -1.56 & $25^{\circ} 45^{\prime} 41^{\prime \prime}$ & $80^{\circ} 30^{\prime} 10^{\prime \prime}$ & 549864.367 & 2849342.306 & Yes \\
\hline S334_T & 239 & Structure & SFWMD & -1.56 & $25^{\circ} 45^{\prime} 41^{\prime \prime}$ & $80^{\circ} 30^{\prime} 05^{\prime \prime}$ & 549992.447 & 2849340.372 & Yes \\
\hline S336_H & 240 & Structure & SFWMD & -1.56 & $25^{\circ} 45^{\prime} 40^{\prime \prime}$ & $80^{\circ} 29^{\prime} 50^{\prime \prime}$ & 550405.970 & 2849339.799 & No \\
\hline S336_T & 241 & Structure & SFWMD & -1.56 & $25^{\circ} 45^{\prime} 40^{\prime \prime}$ & $80^{\circ} 29^{\prime} 48^{\prime \prime}$ & 550486.990 & 2849335.273 & No \\
\hline S9A_T & 242 & Structure & SFWMD & -1.4 & $26^{\circ} 03^{\prime} 41^{\prime \prime}$ & $80^{\circ} 26^{\prime} 38^{\prime \prime}$ & 555630.460 & 2882614.650 & Yes \\
\hline SITE_69E & 243 & Marsh & USGS & -1.66 & $25^{\circ} 54^{\prime} 24^{\prime \prime}$ & $80^{\circ} 35^{\prime} 19.6^{\prime \prime}$ & 541187.06 & 2865412.2 & No \\
\hline SITE_71 & 244 & Marsh & USGS & -1.57 & $25^{\circ} 53^{\prime} 05^{\prime \prime}$ & $80^{\circ} 33^{\prime} 24^{\prime \prime}$ & 544405.467 & 2863003.279 & Yes \\
\hline SITE_76 & 245 & Marsh & USGS & -1.5 & $26^{\circ} 00^{\prime} 28^{\prime \prime}$ & $80^{\circ} 28^{\prime} 57^{\prime \prime}$ & 551781.677 & 2876657.809 & Yes \\
\hline SRS1 & 246 & Marsh & USGS & -1.54 & $25^{\circ} 47^{\prime} 55^{\prime \prime}$ & $80^{\circ} 34^{\prime} 42^{\prime \prime}$ & 542265.461 & 2853460.280 & Yes \\
\hline TI-9 & 247 & Marsh & USGS & -1.53 & $25^{\circ} 50^{\prime} 14^{\prime \prime}$ & $80^{\circ} 35^{\prime} 58^{\prime \prime}$ & 540141.954 & 2857718.584 & Yes \\
\hline
\end{tabular}

${ }^{1}$ Located northwest of Water Conservation Area 3A. 


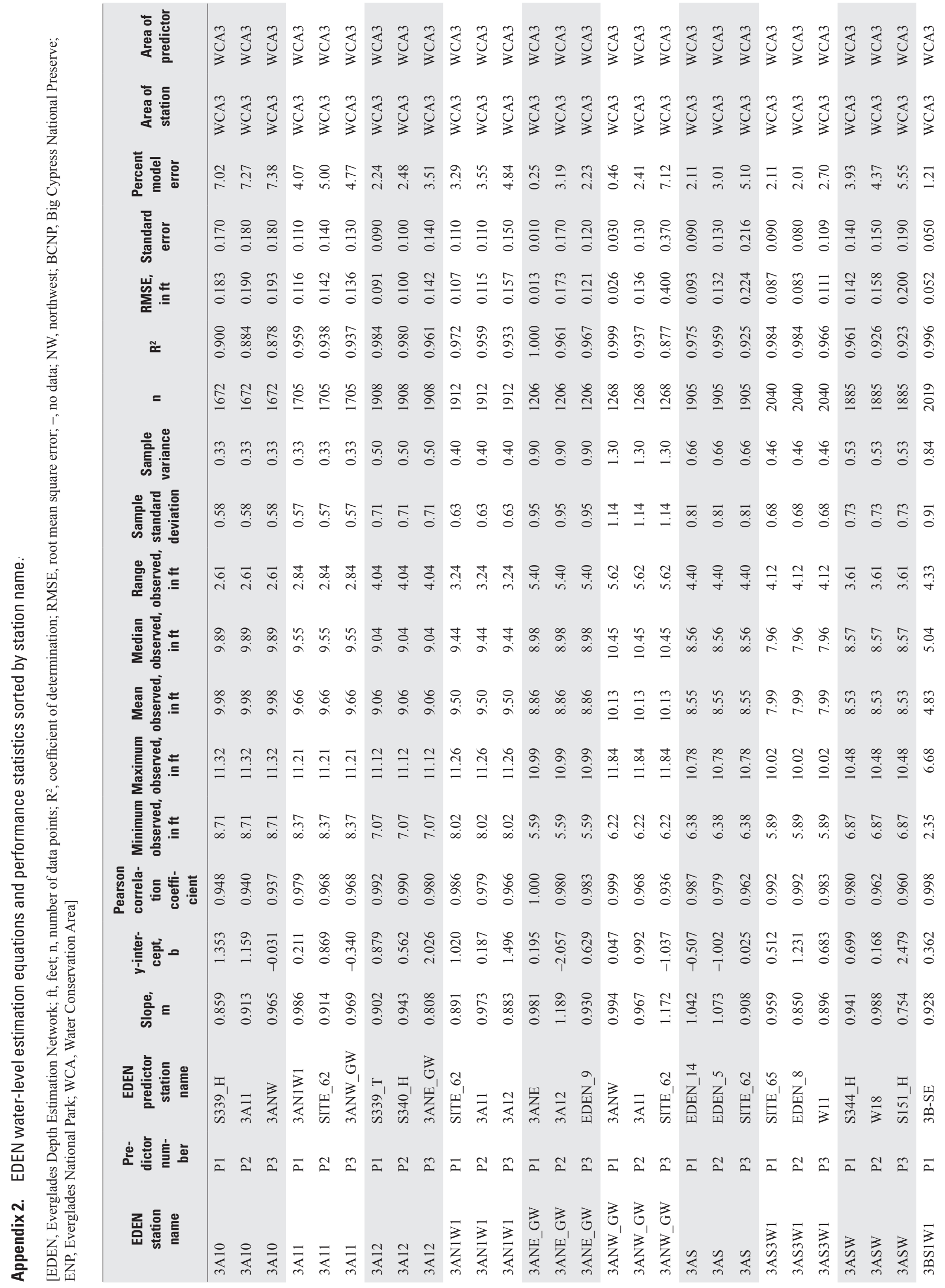




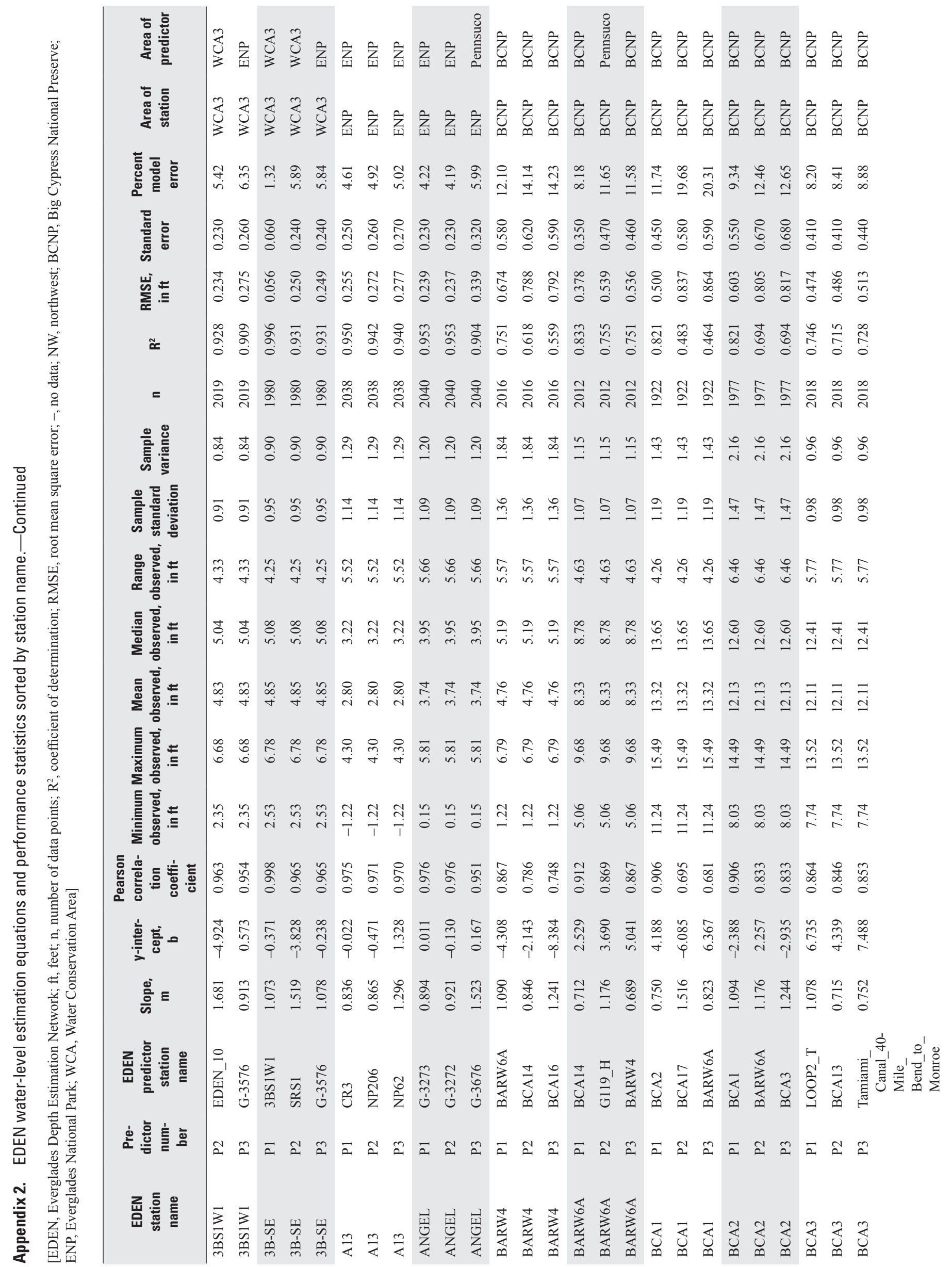




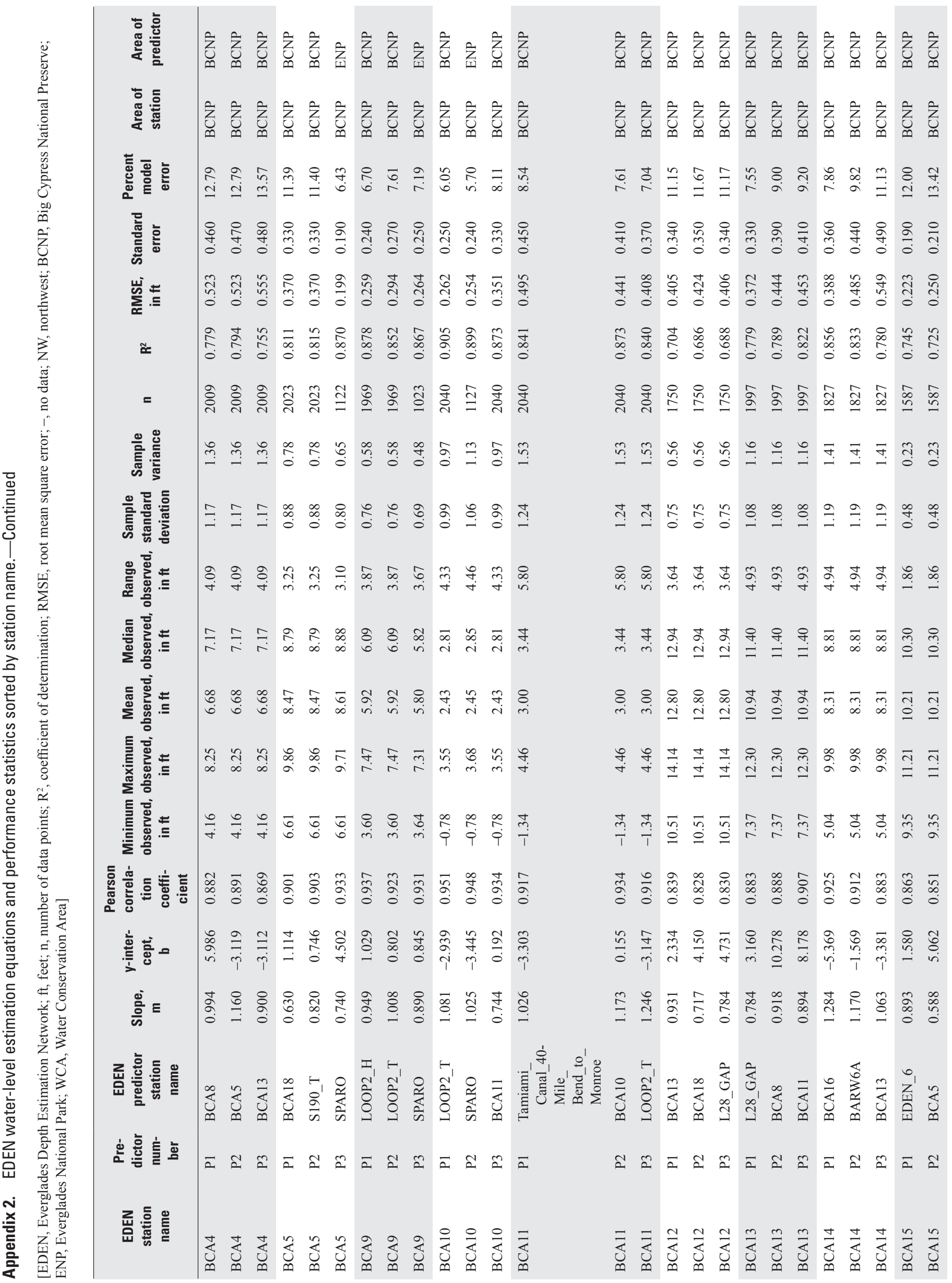




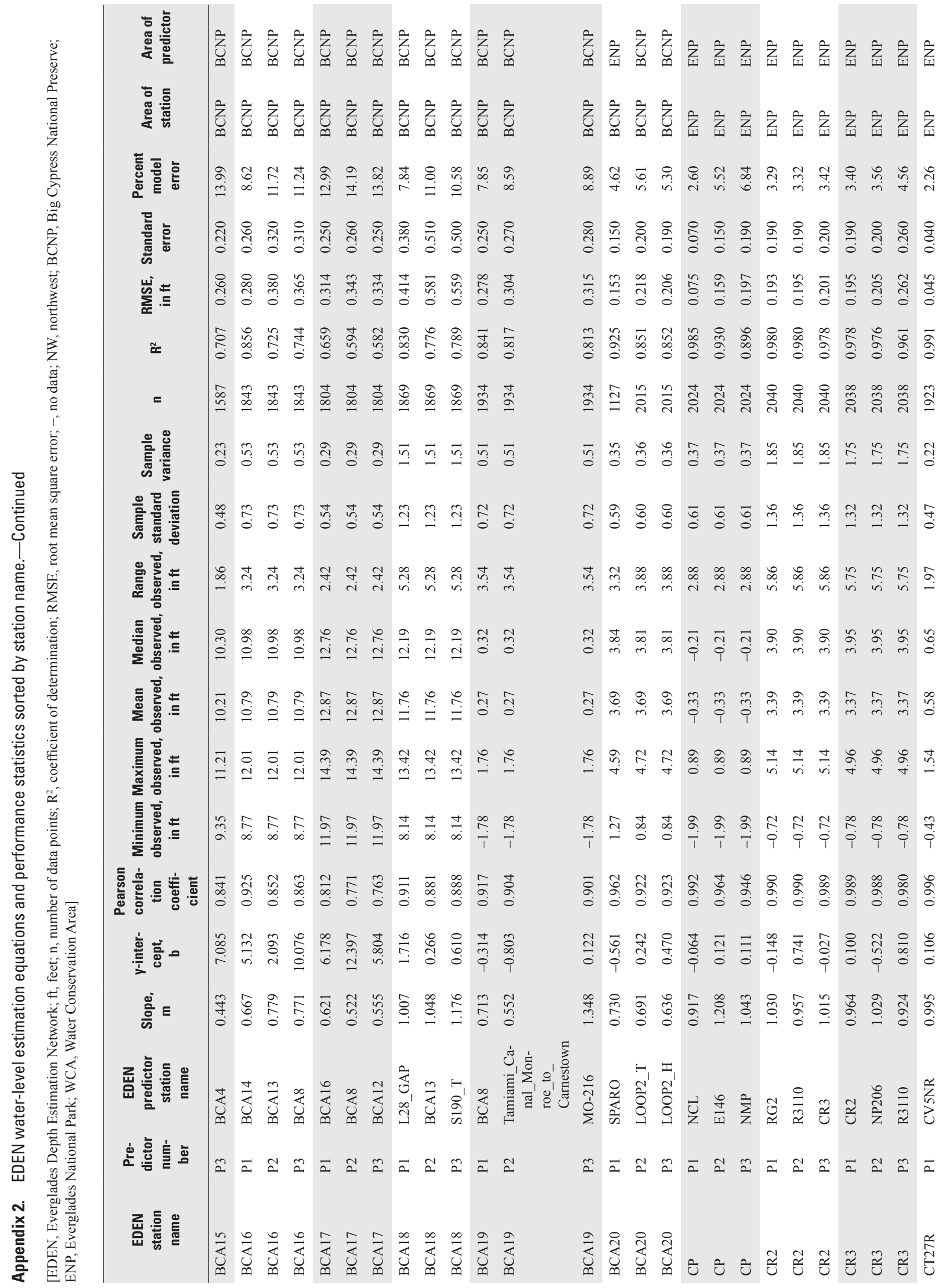




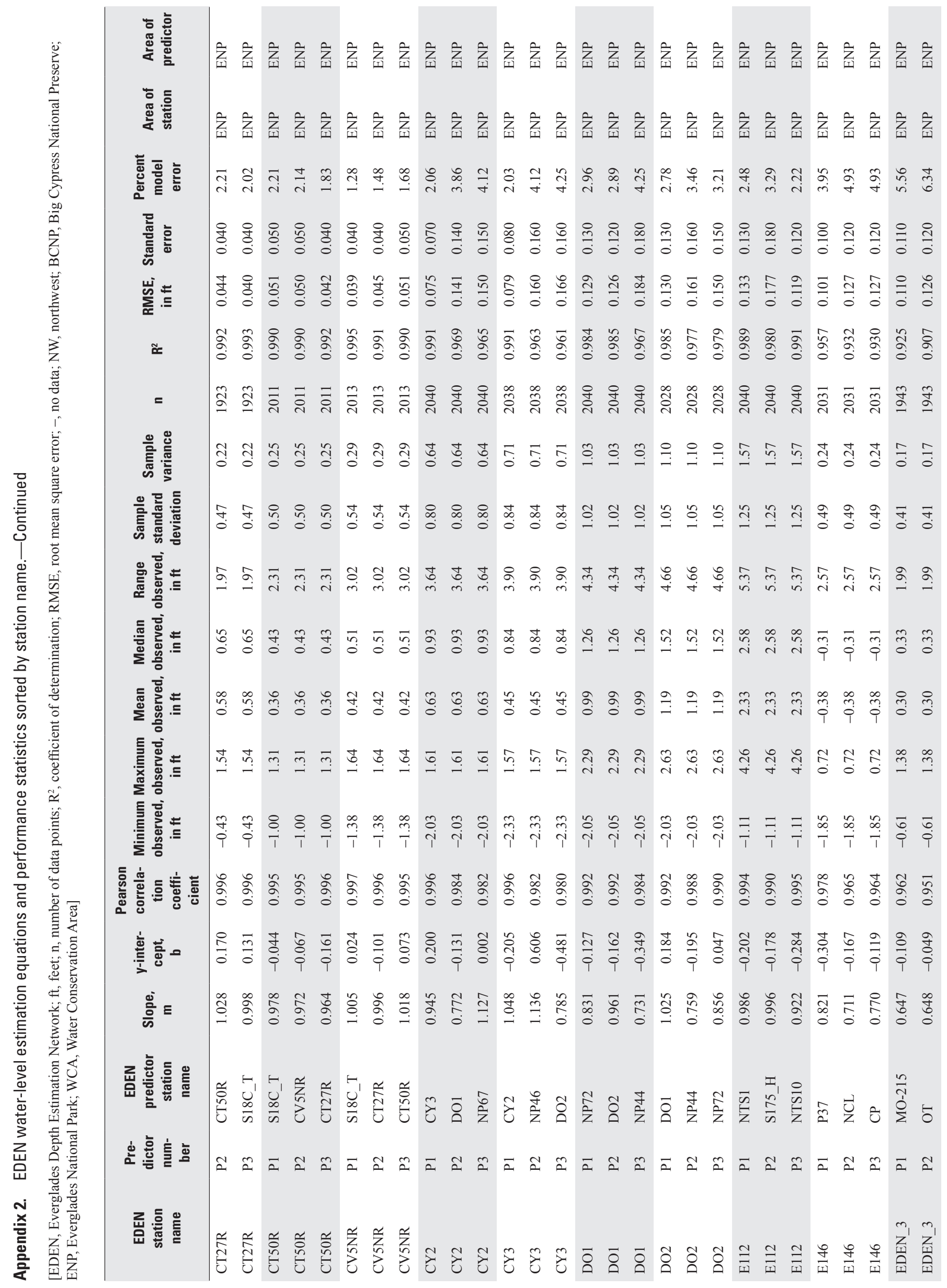




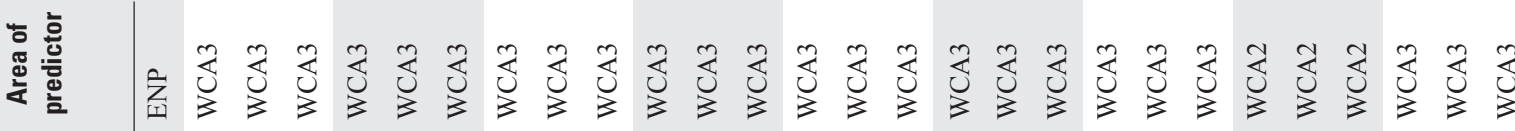

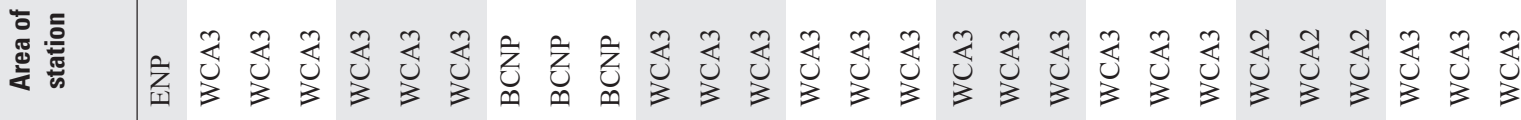

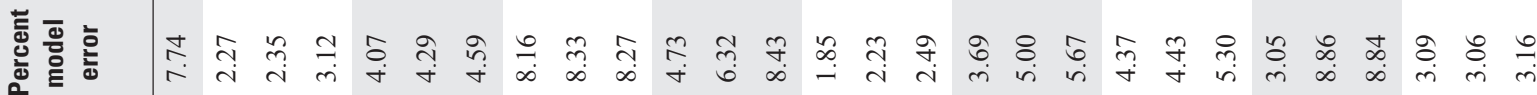
荡

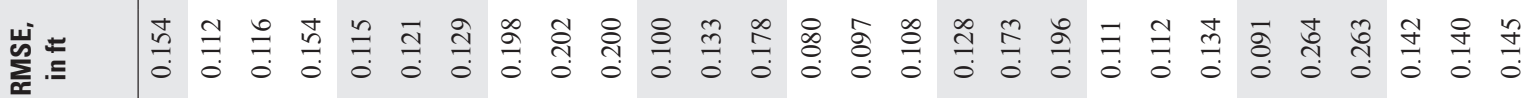

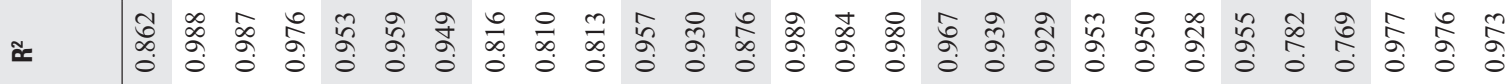

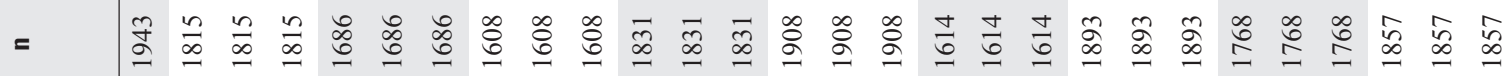
高

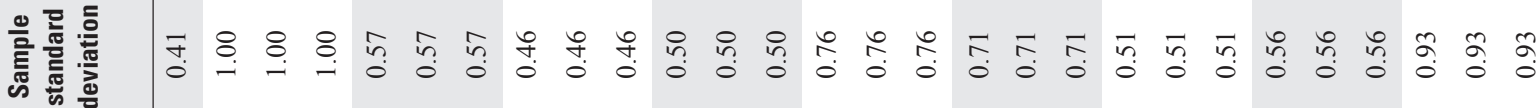

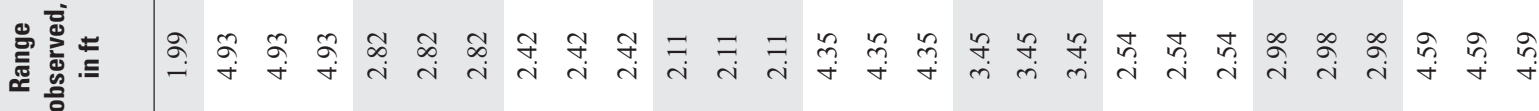

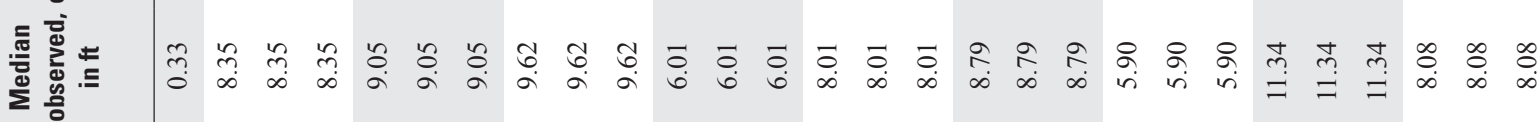

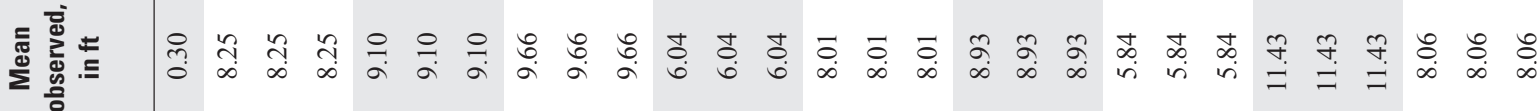

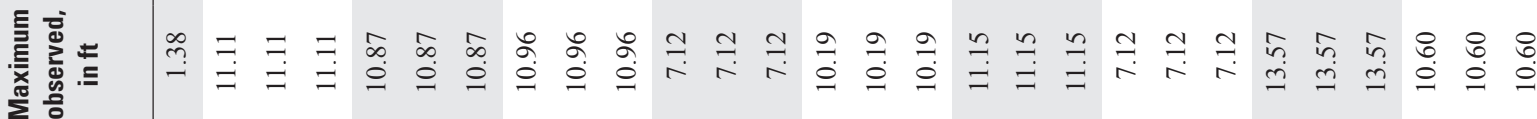

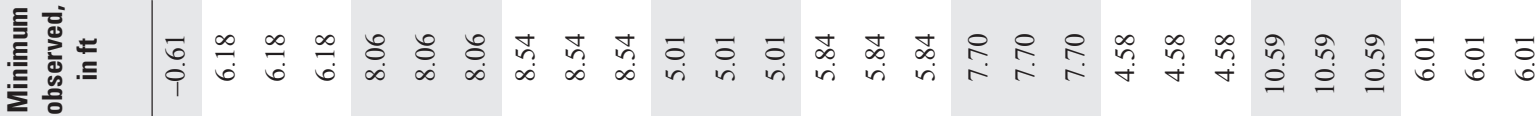

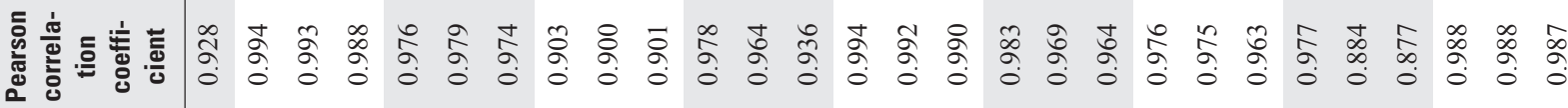

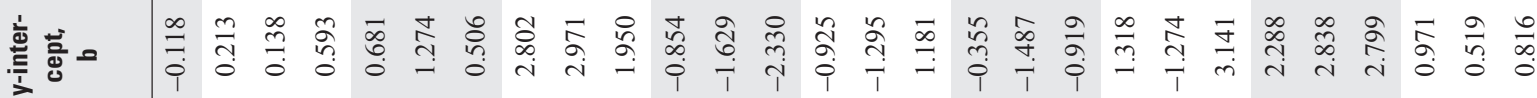

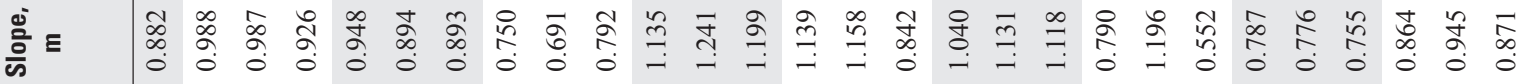

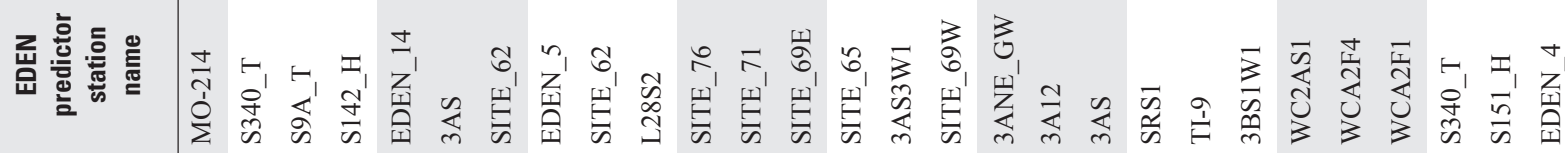

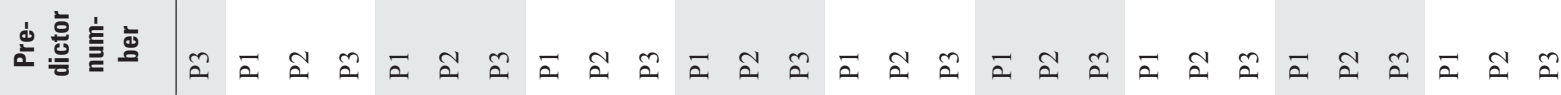

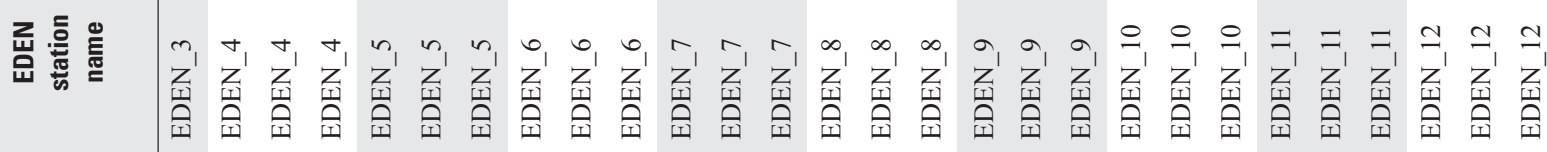




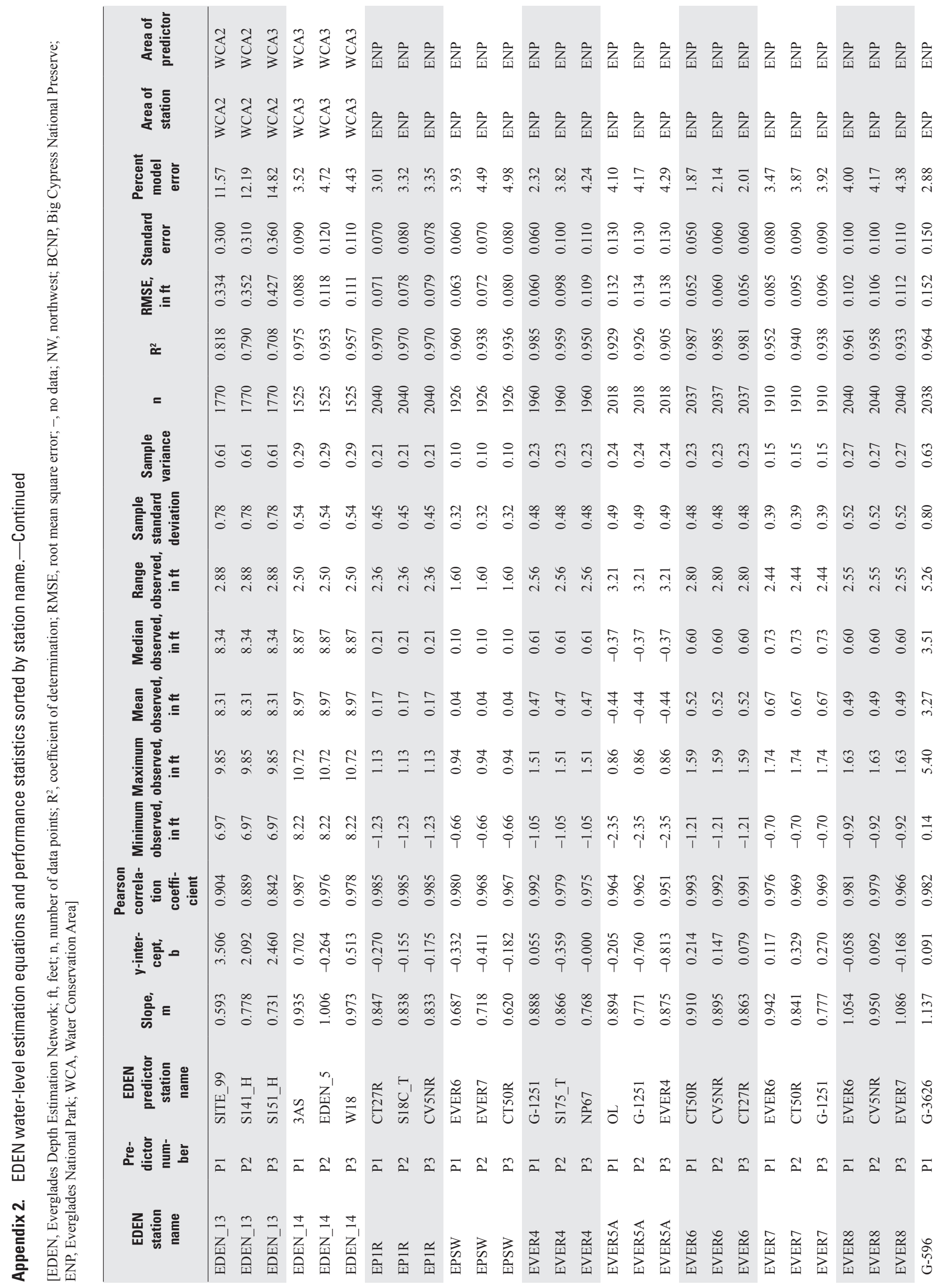




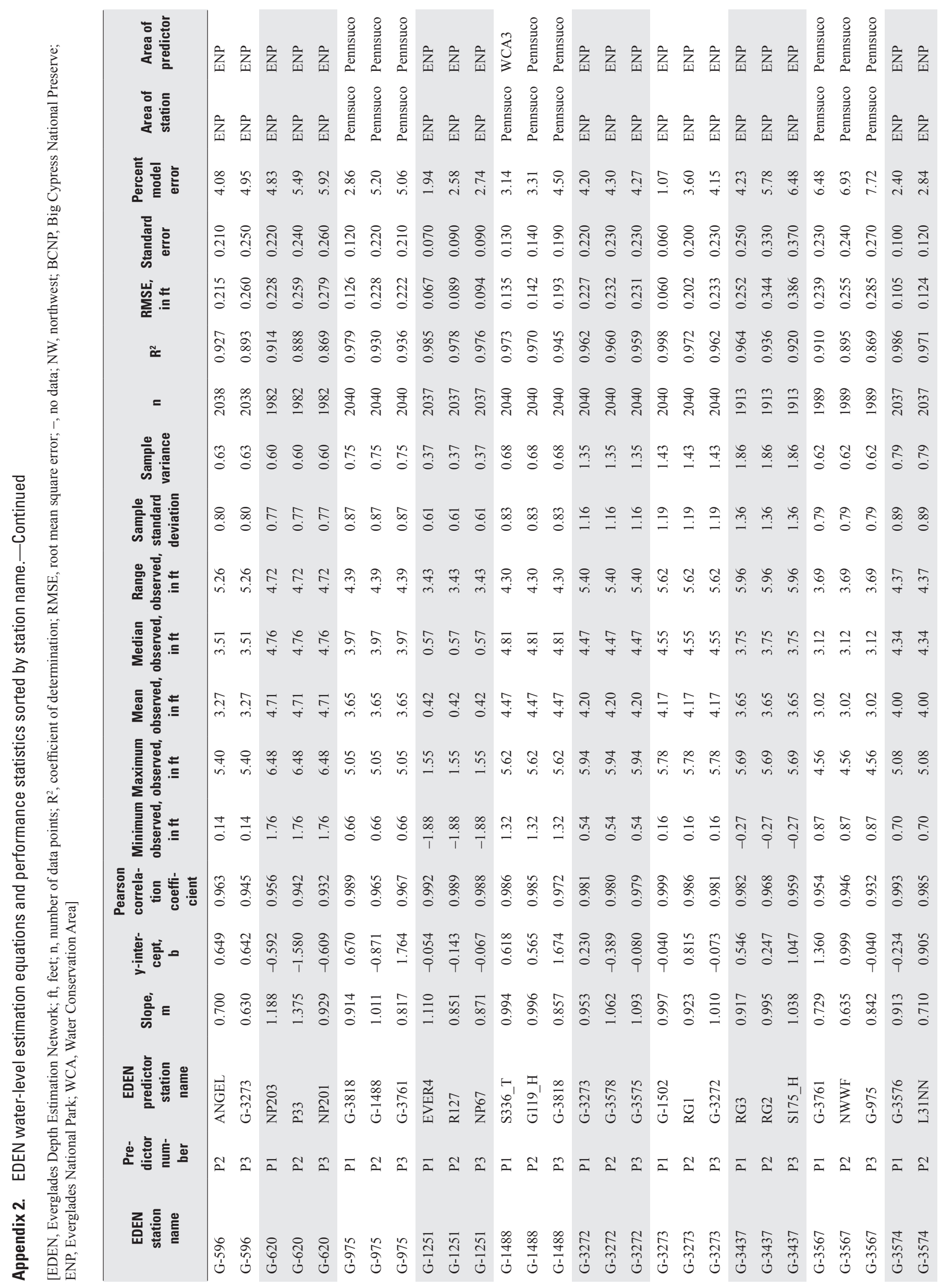




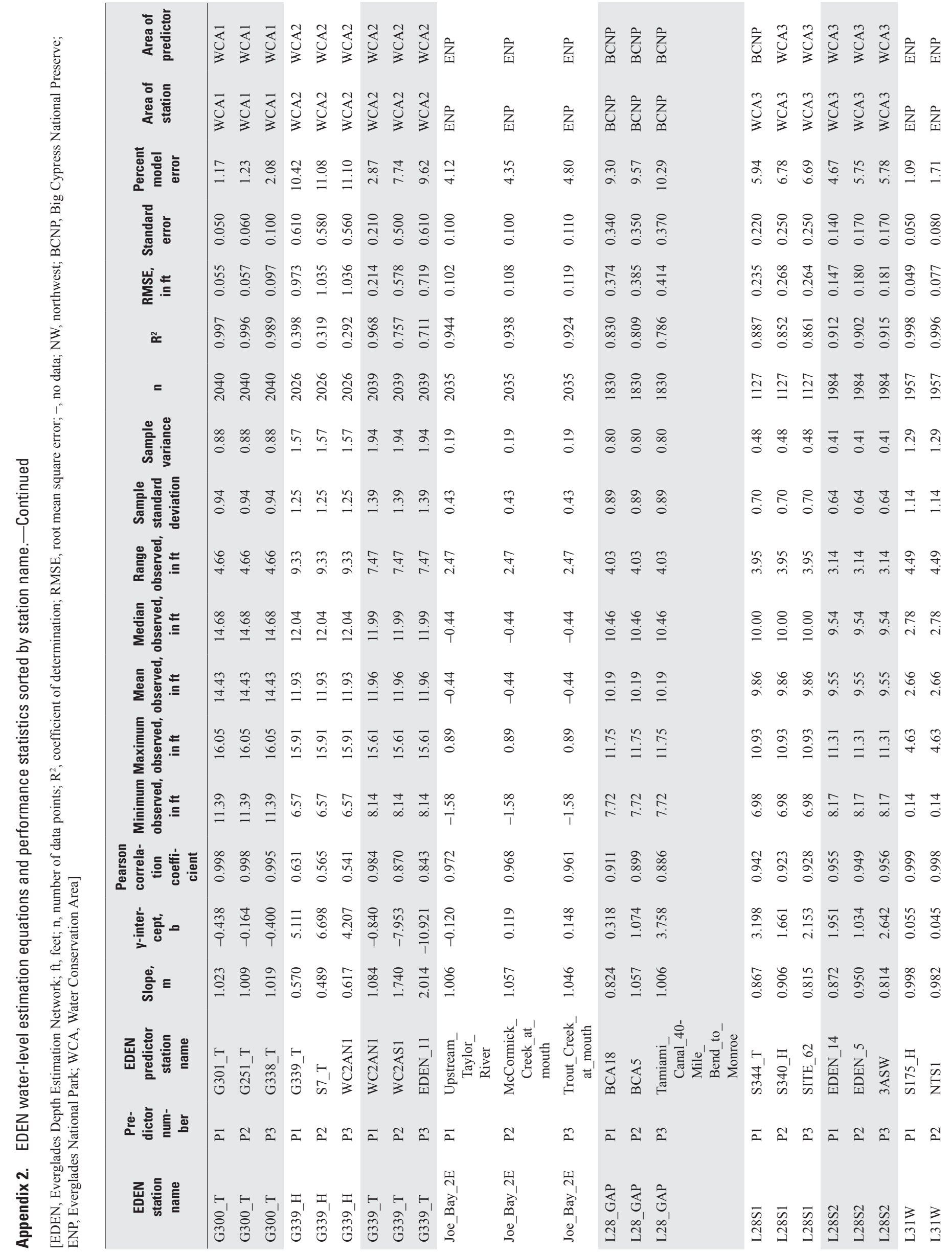




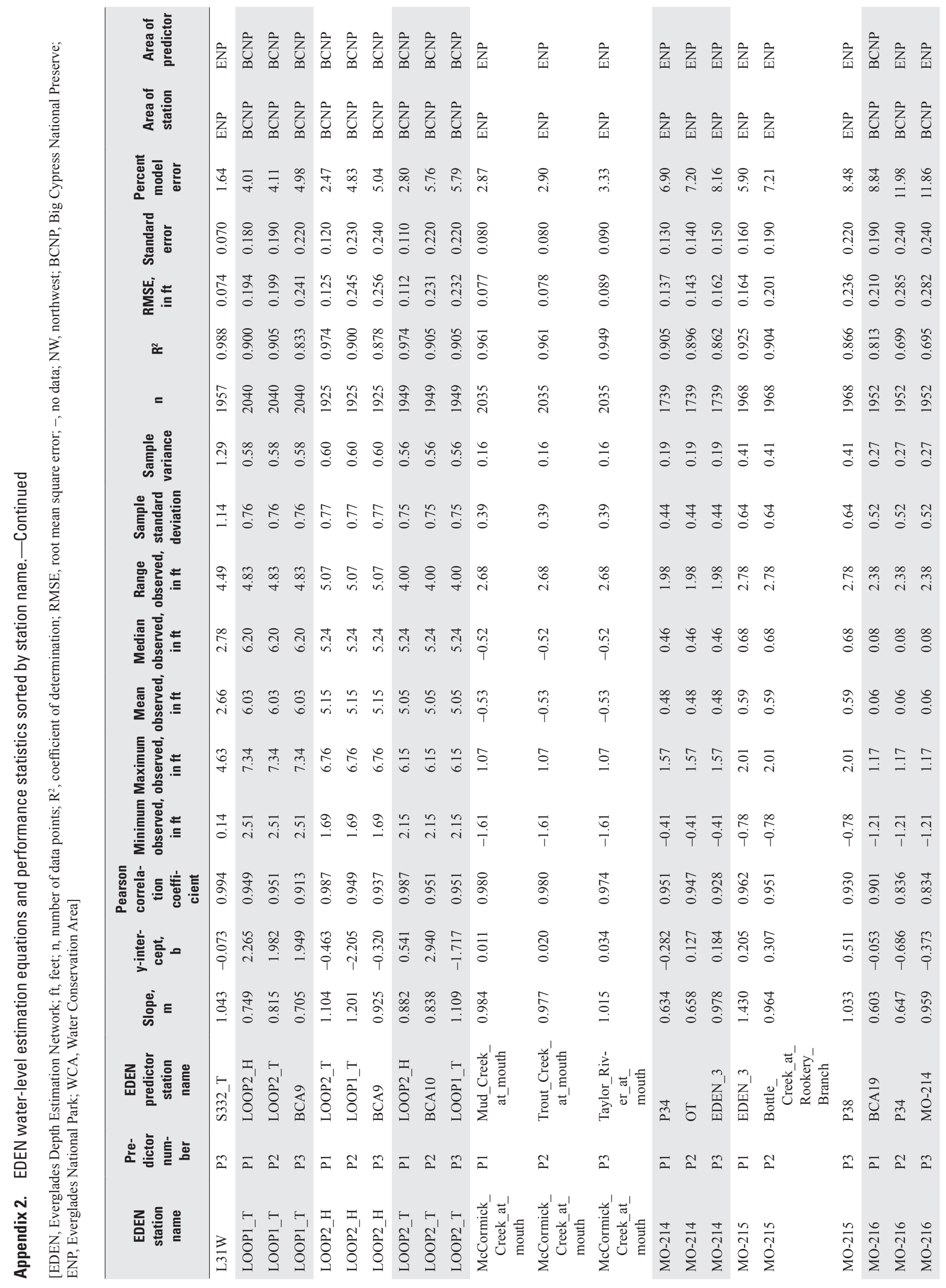




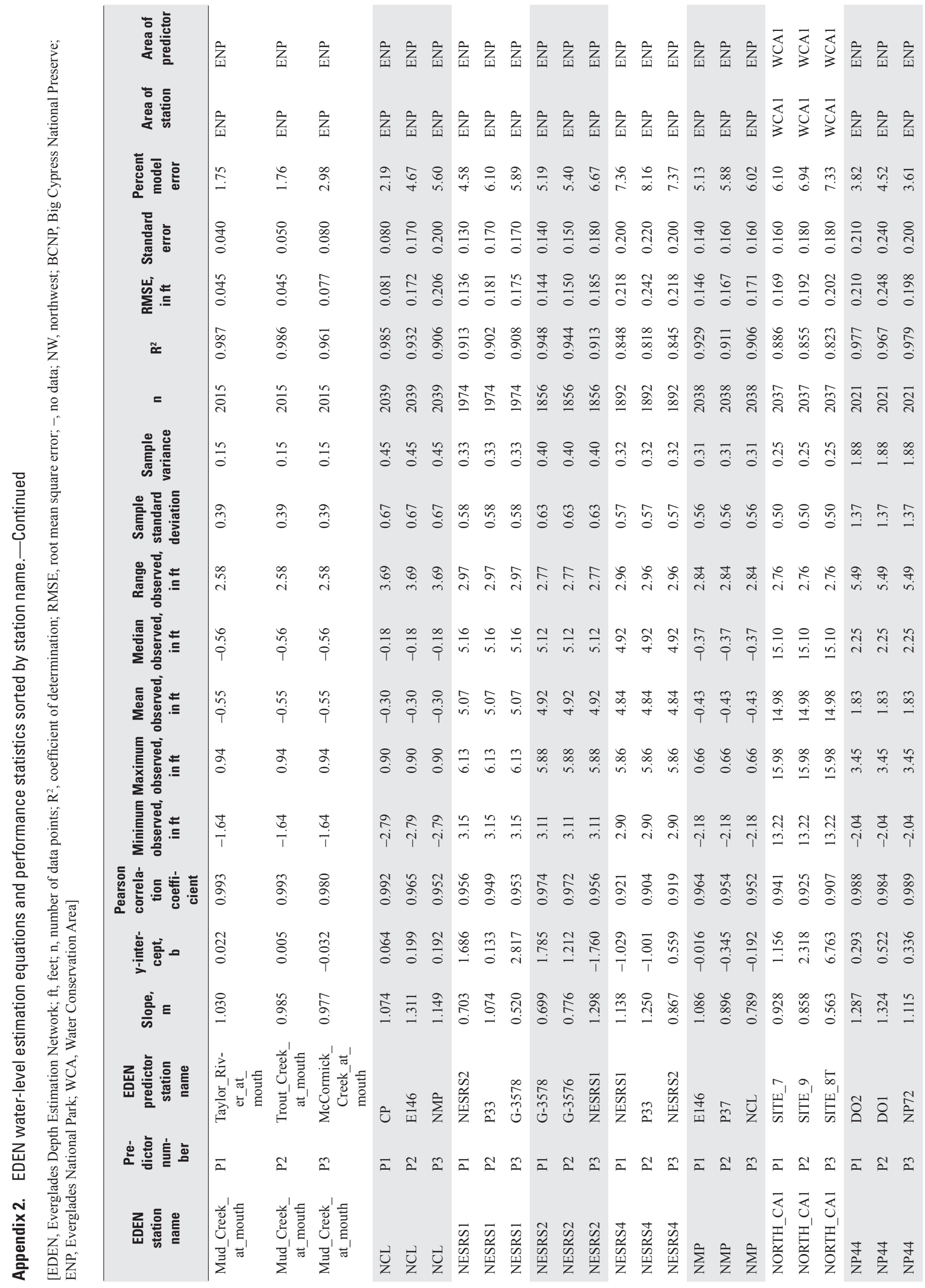




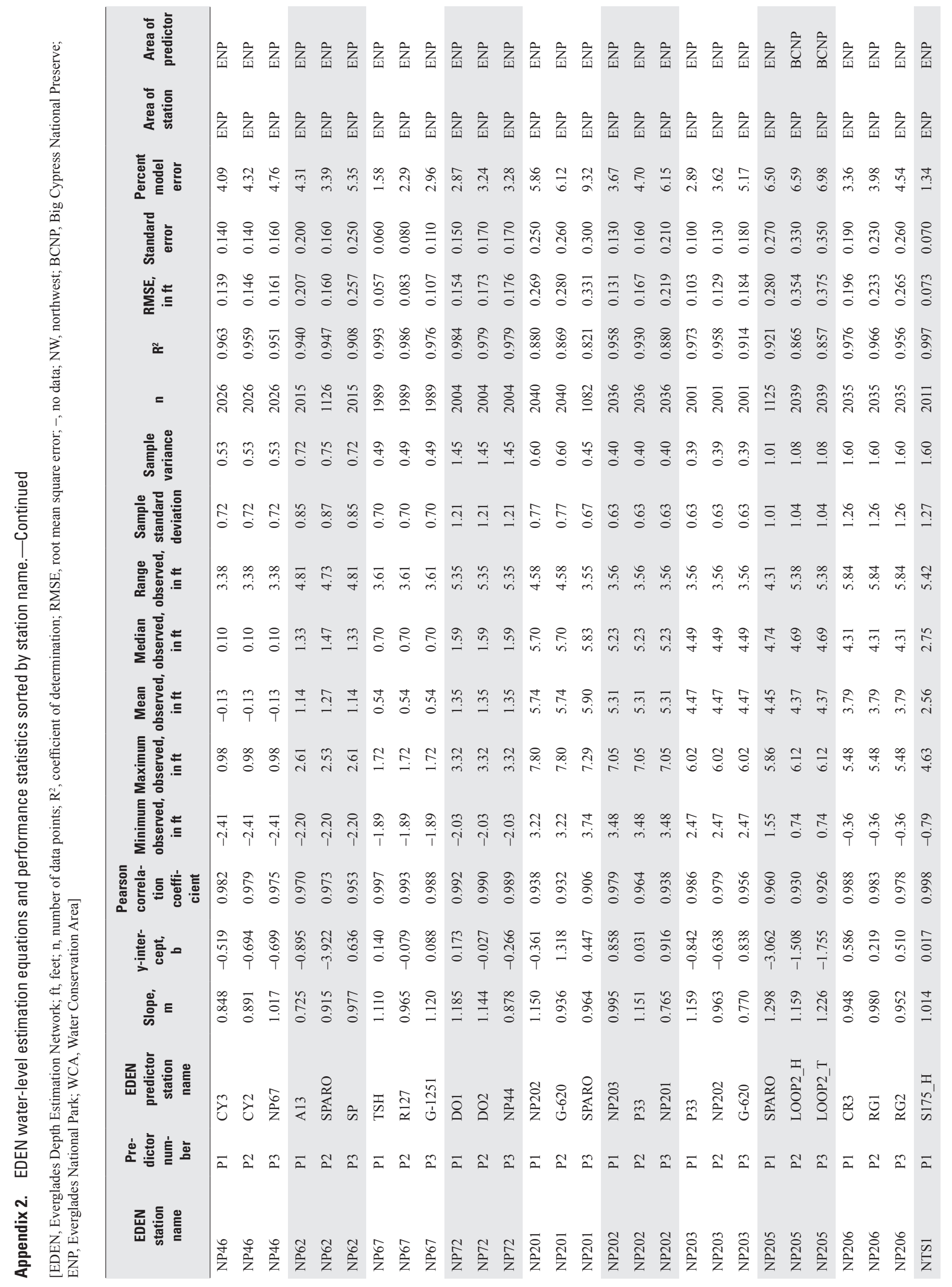




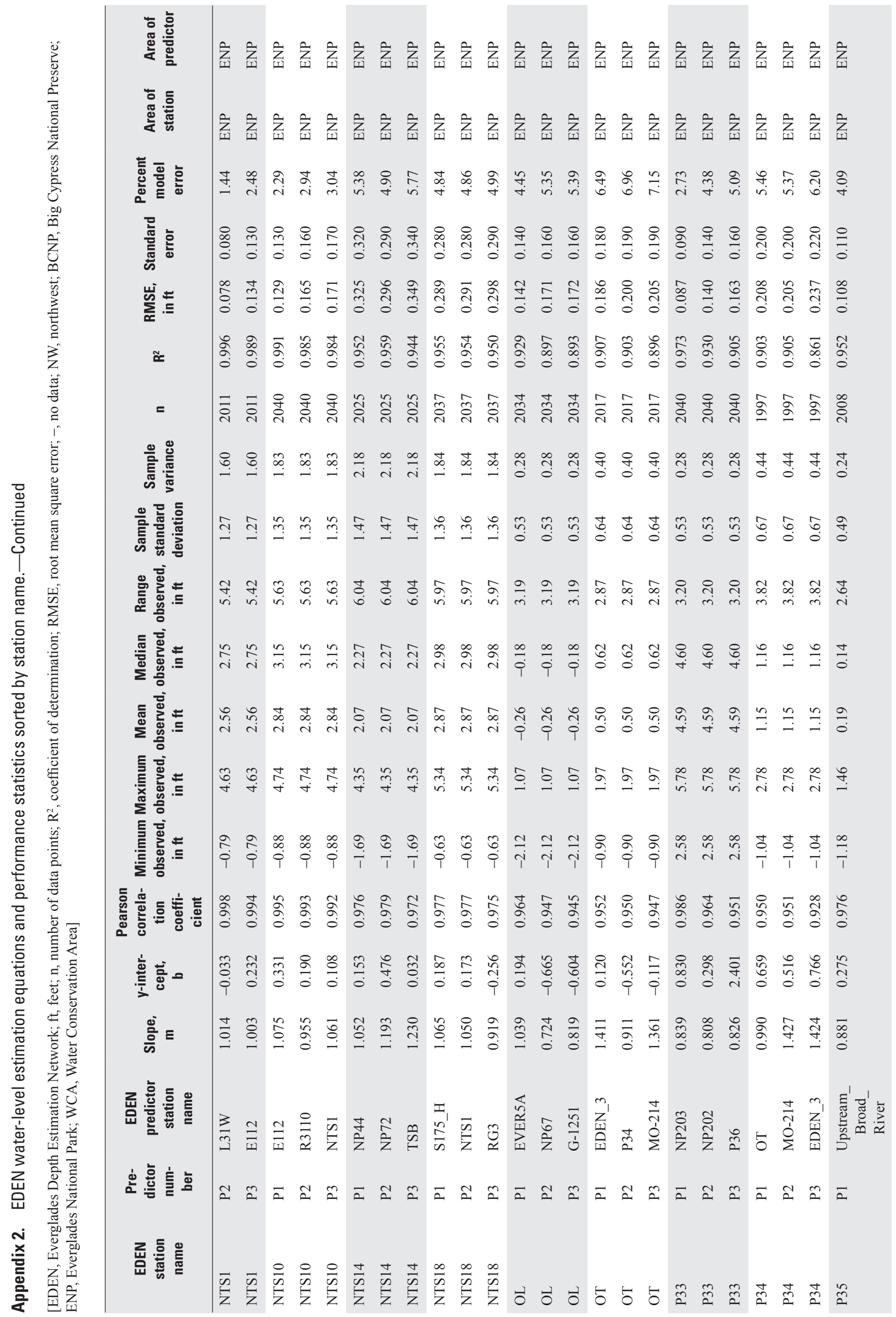




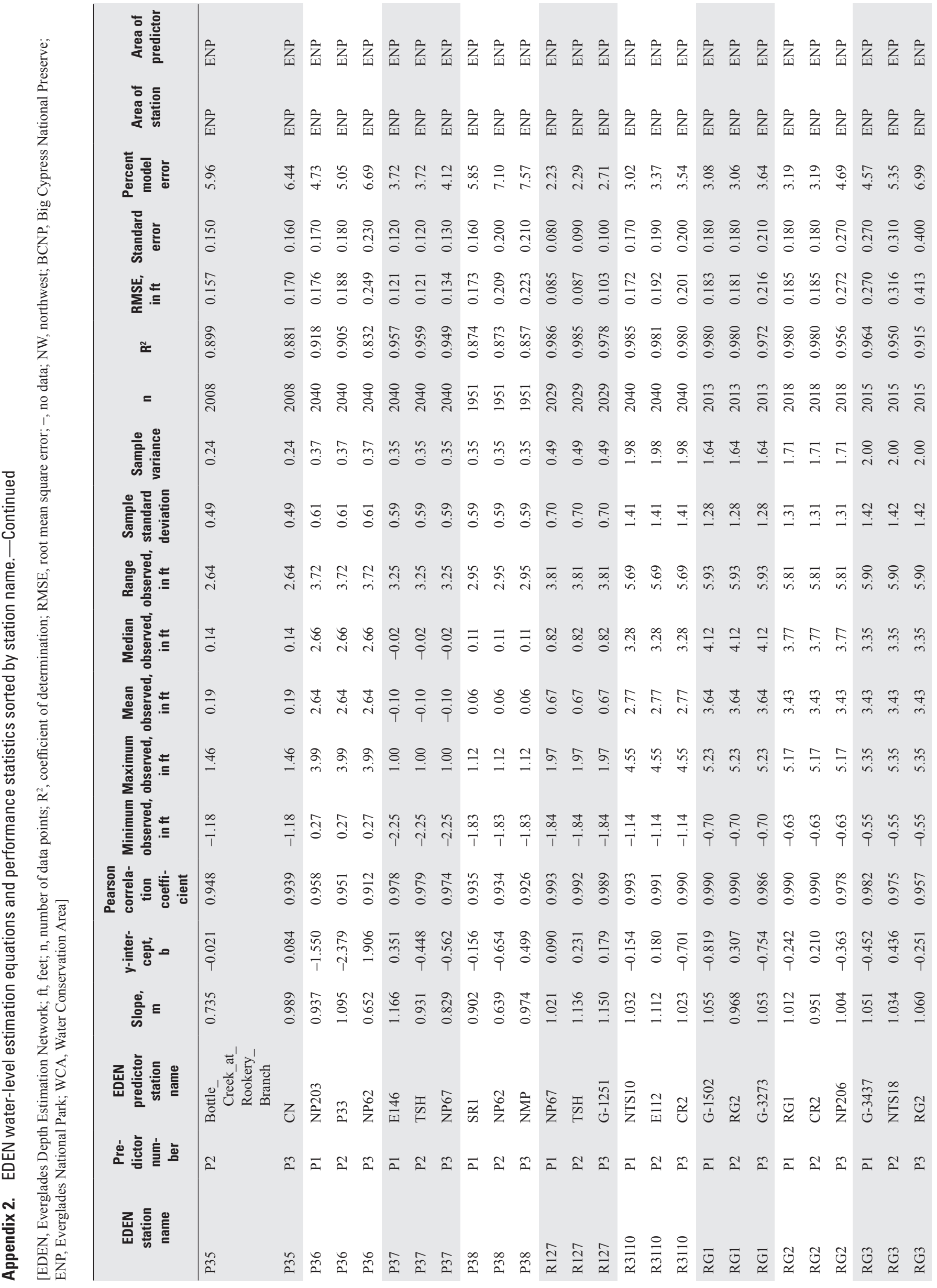




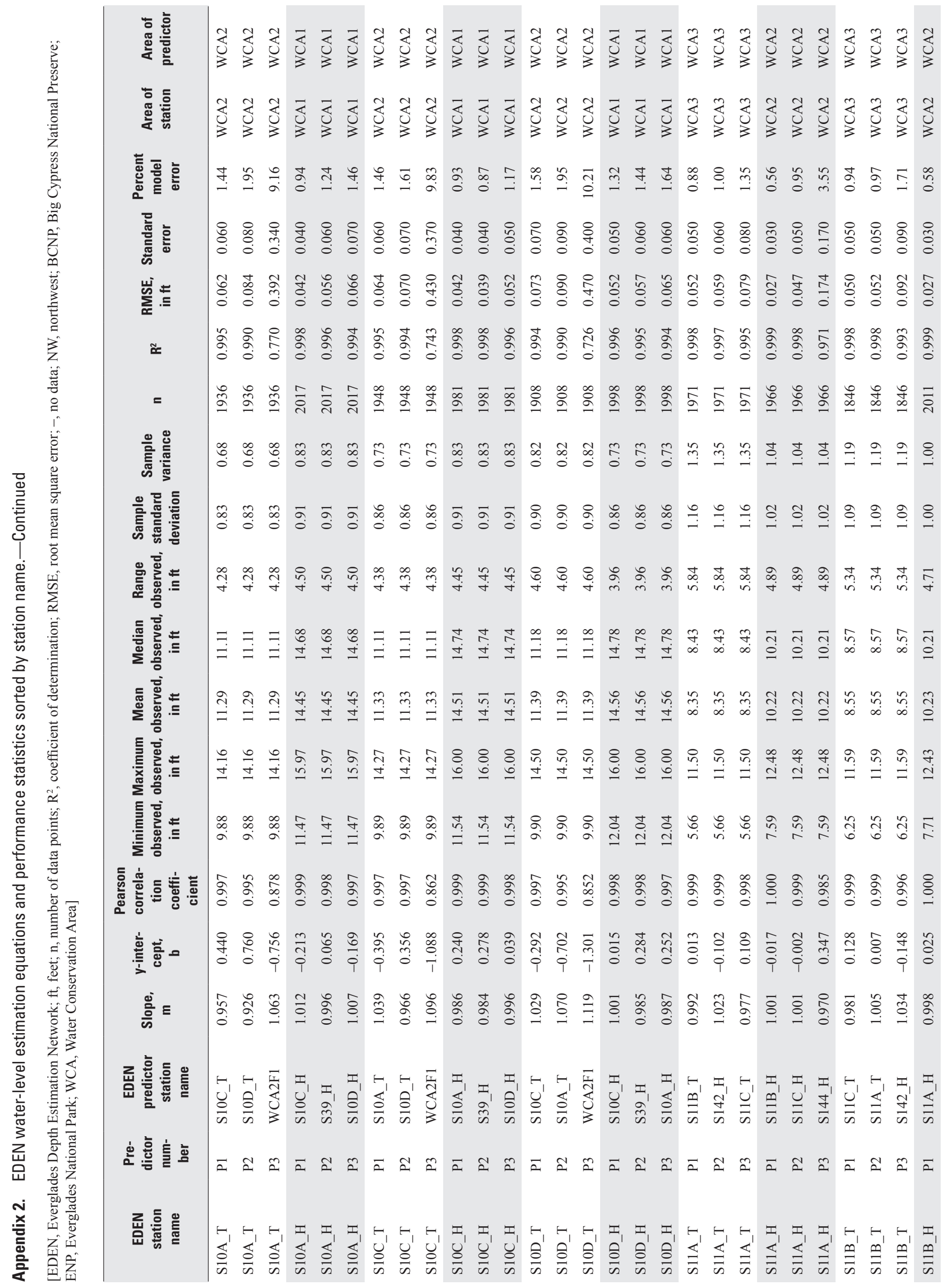




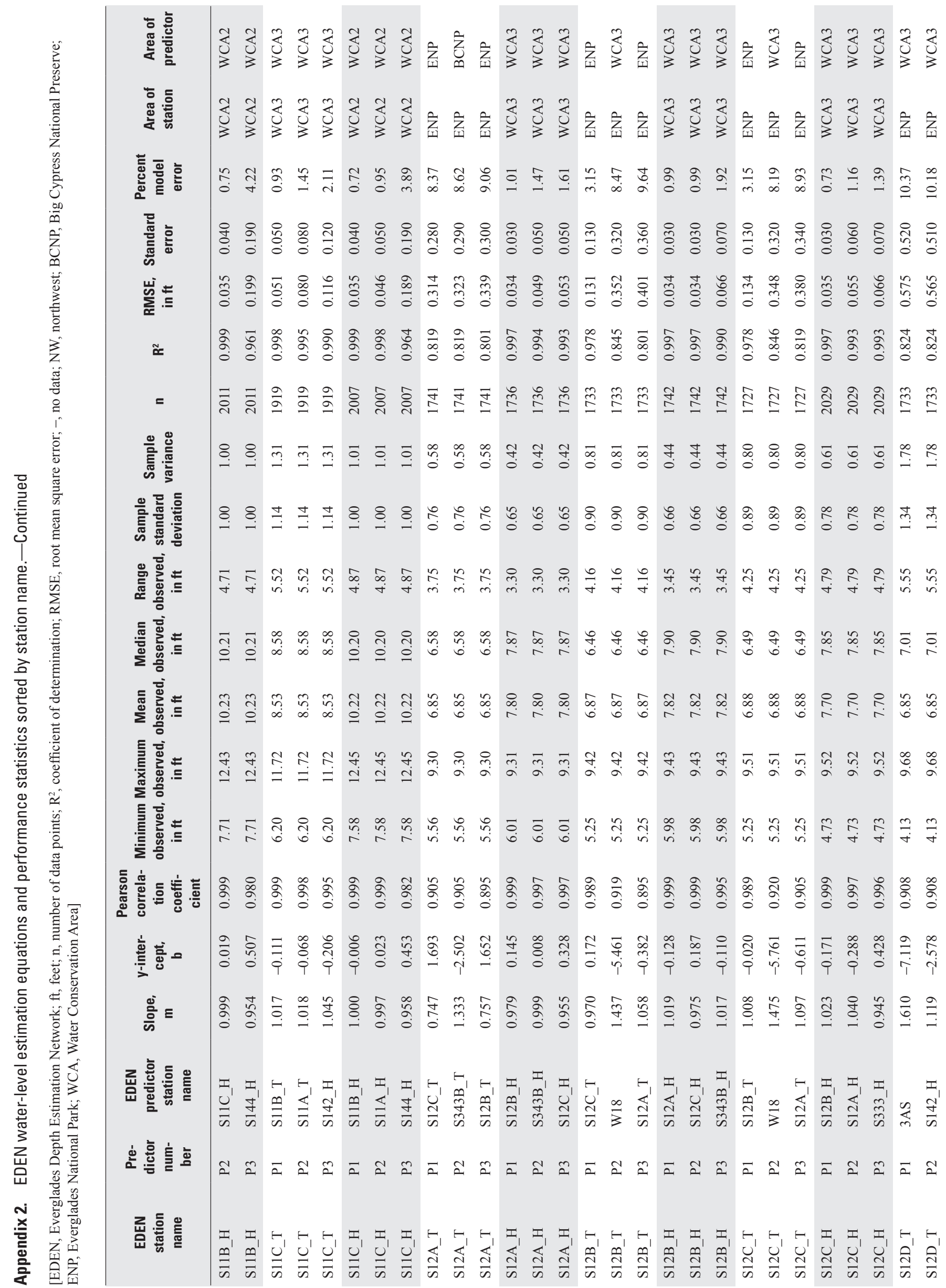




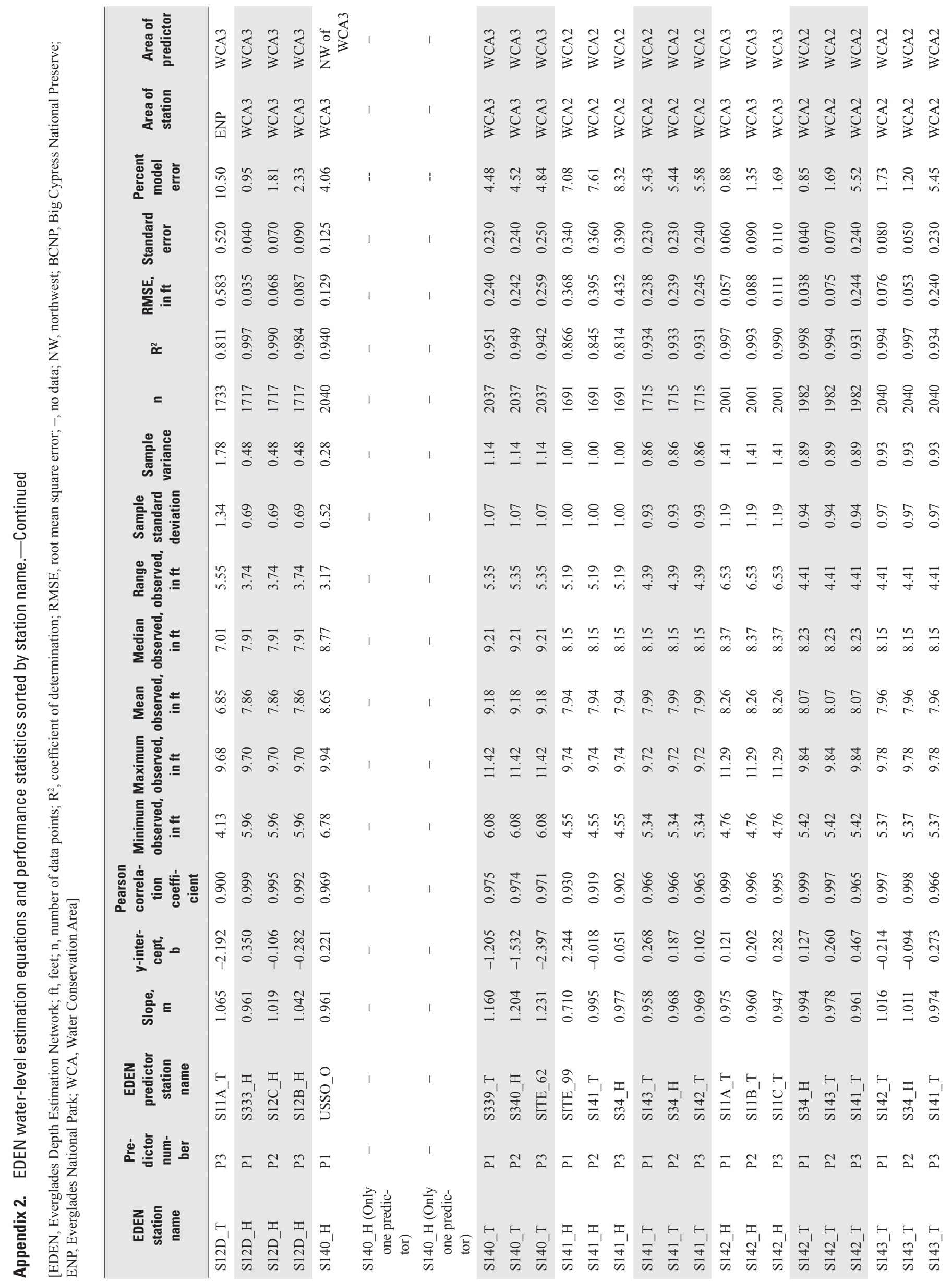




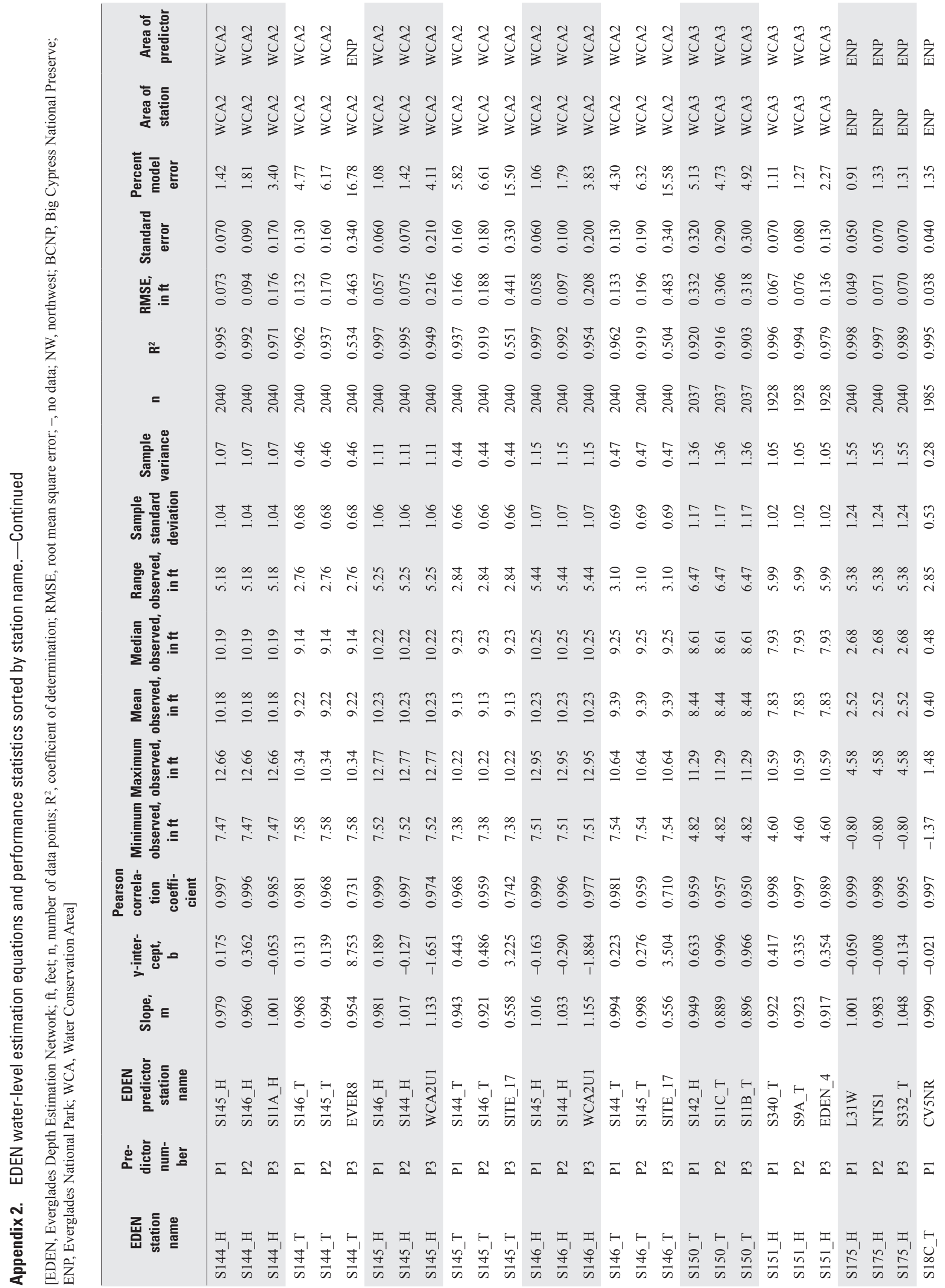




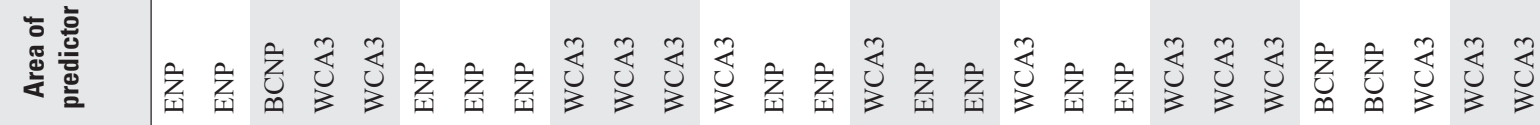

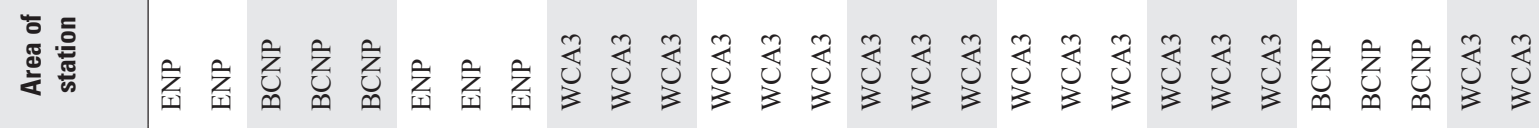

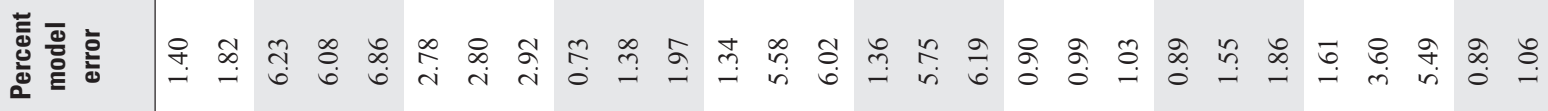

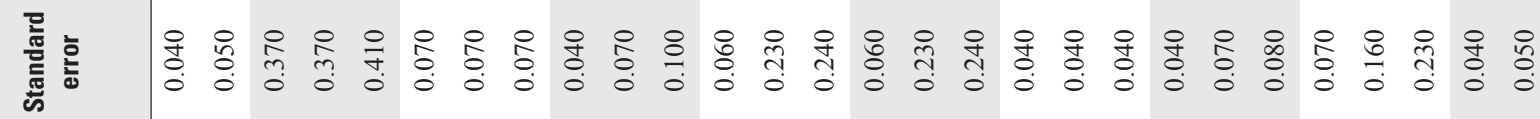

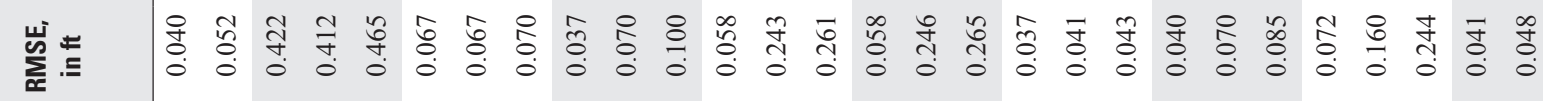

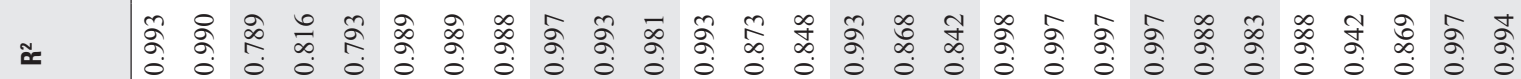

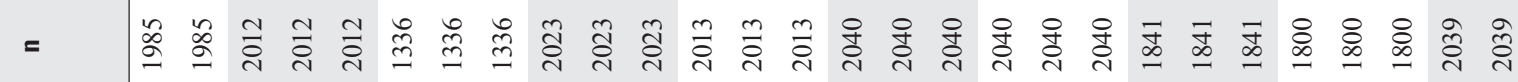

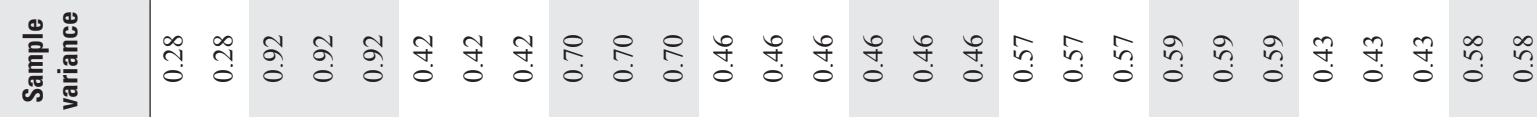

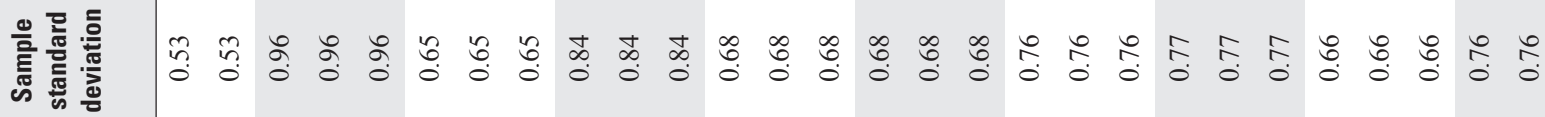

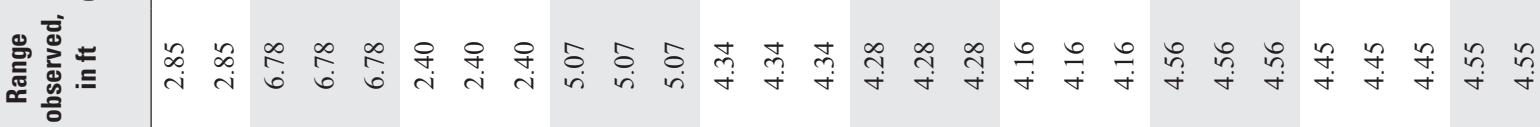

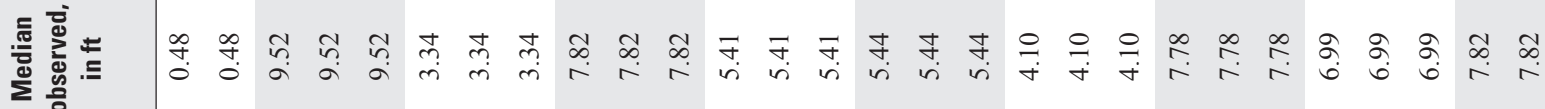

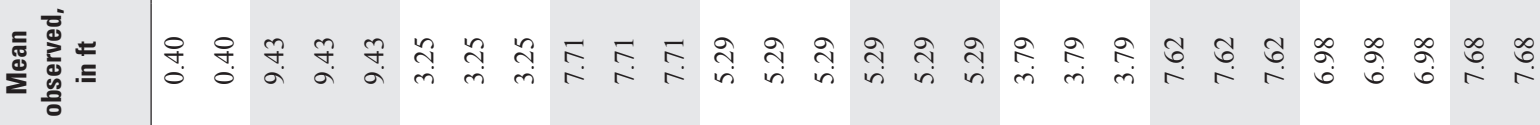

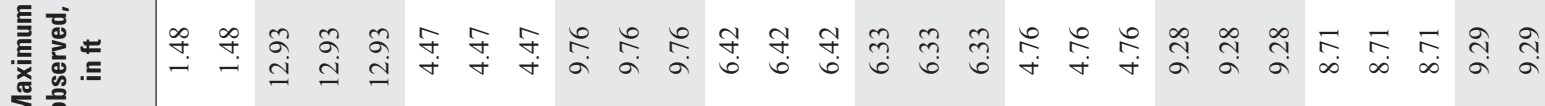

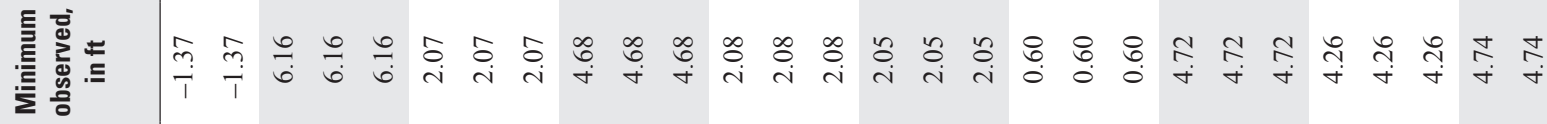

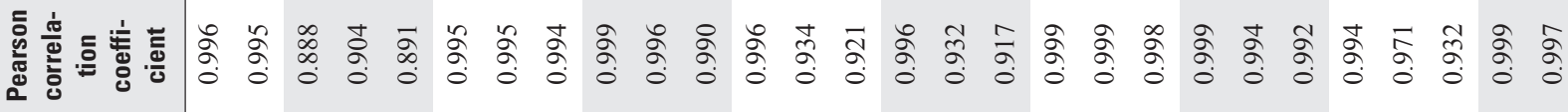

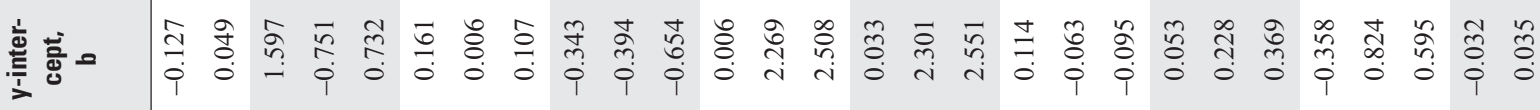

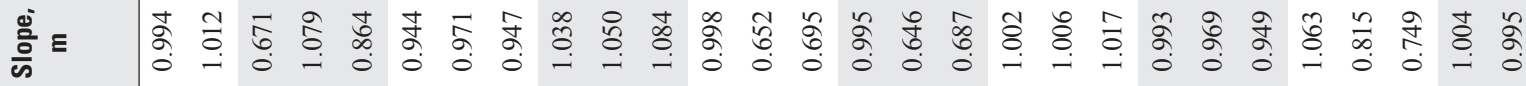

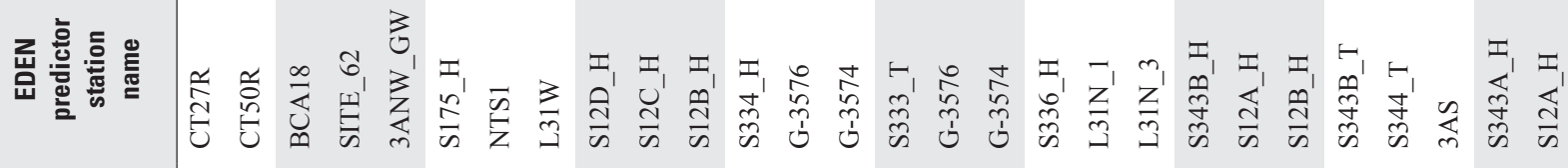
๖ำ

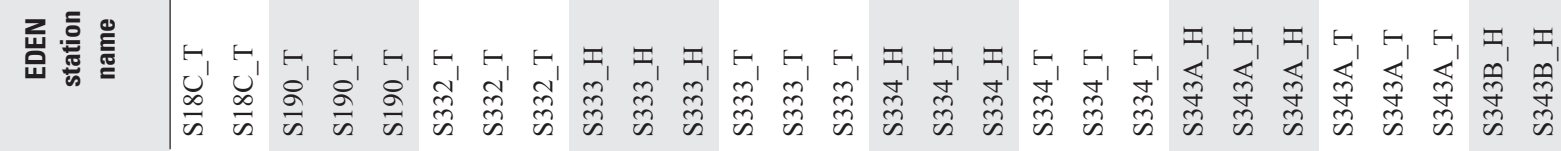




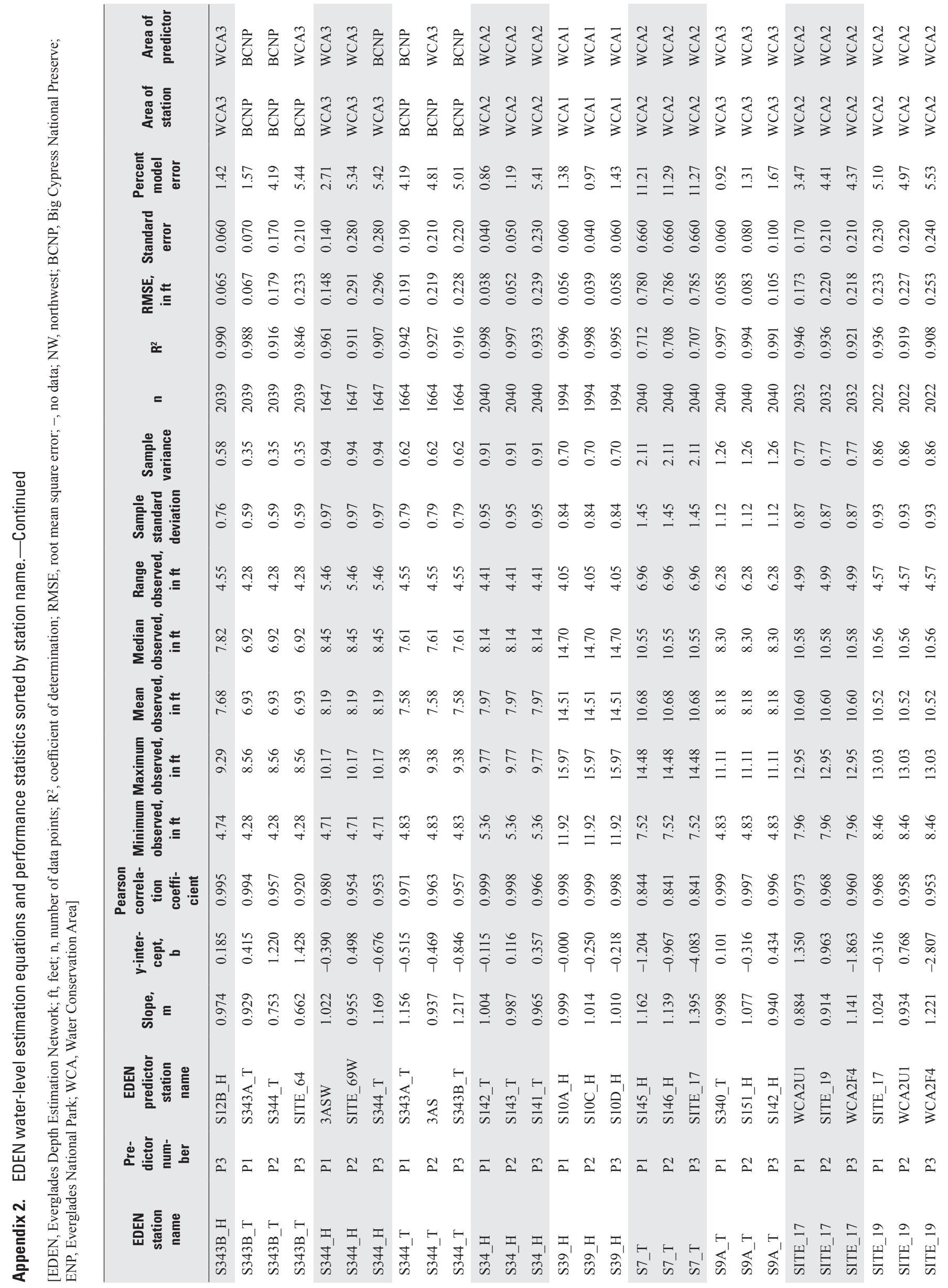




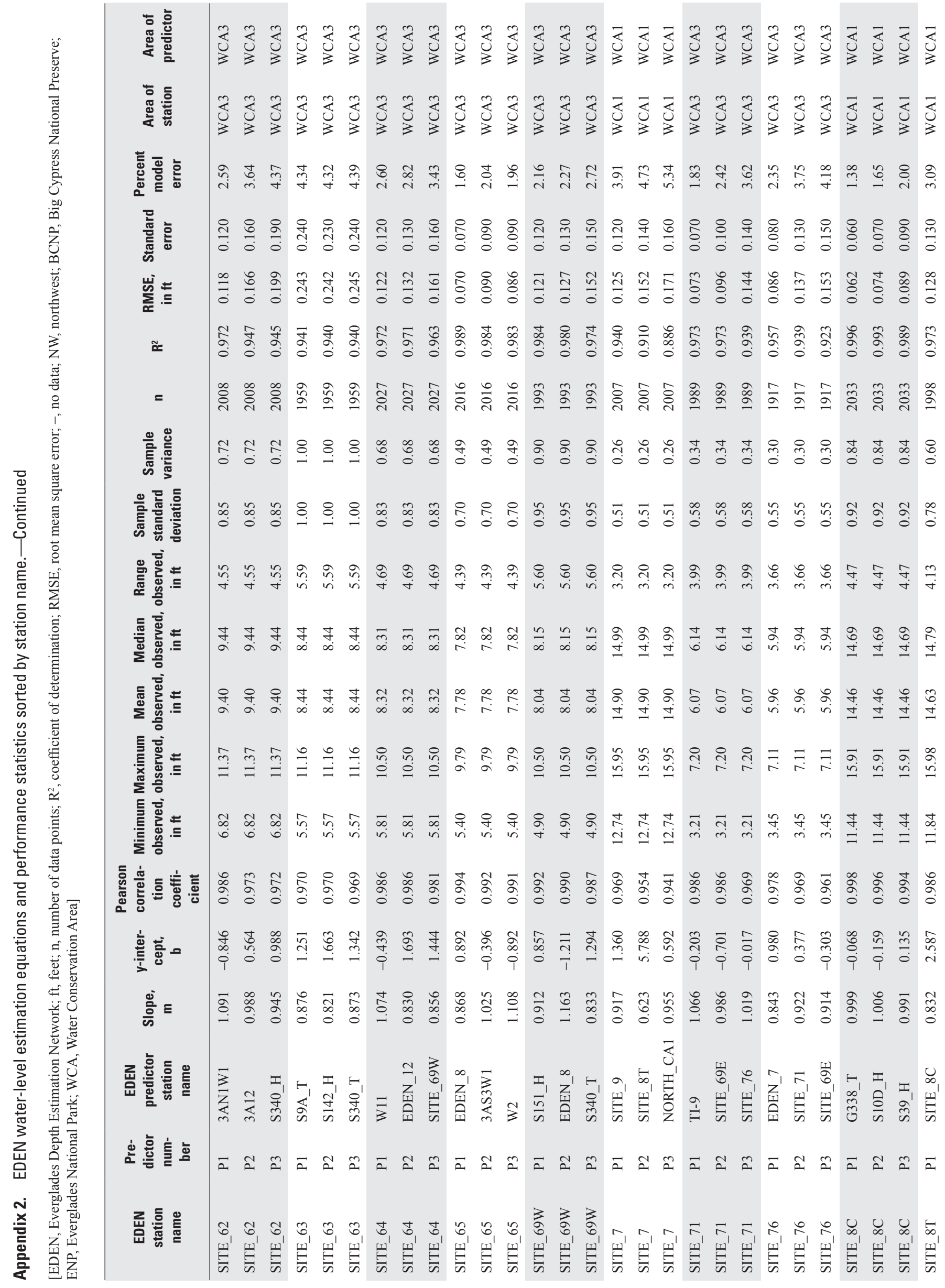




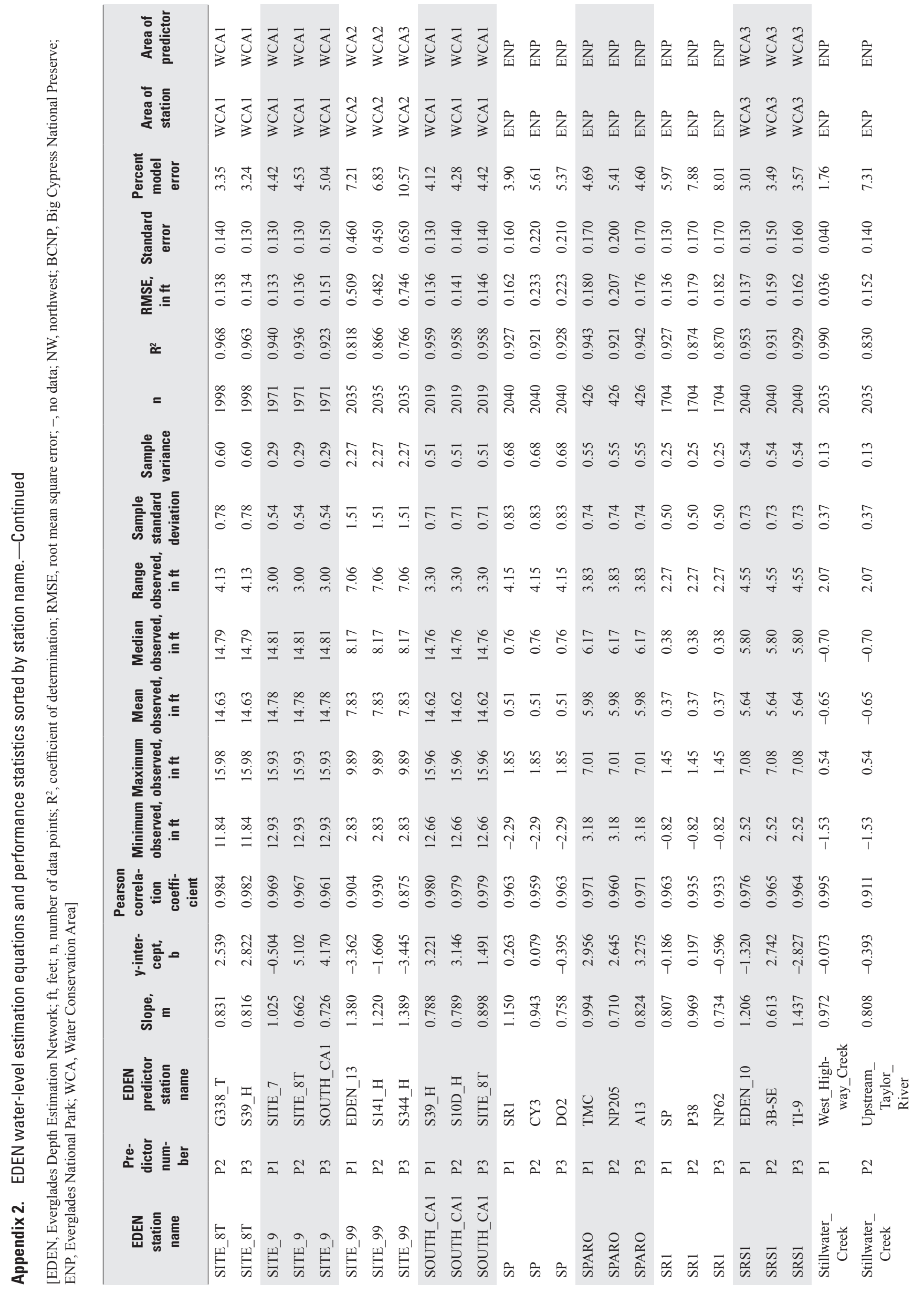




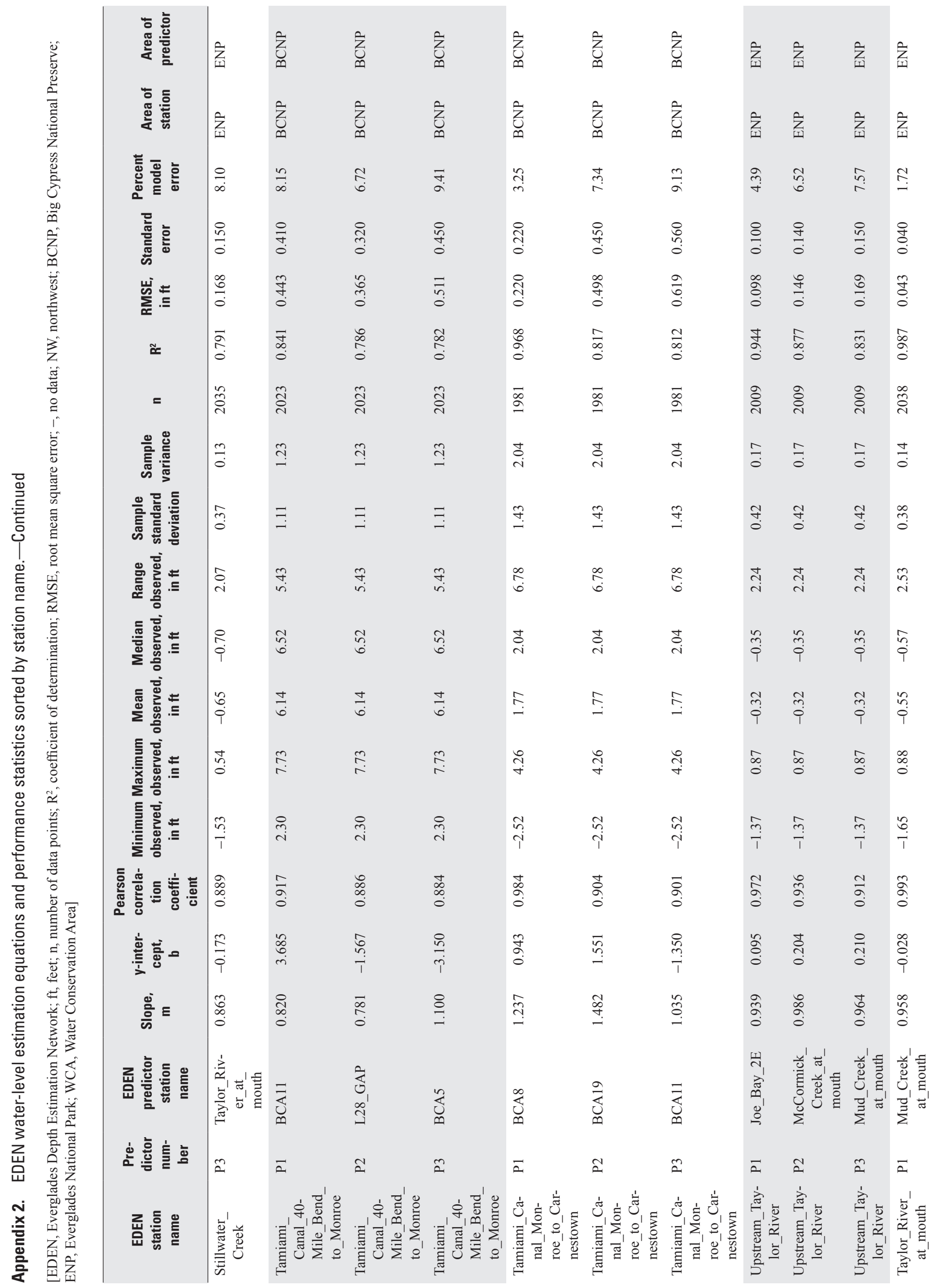




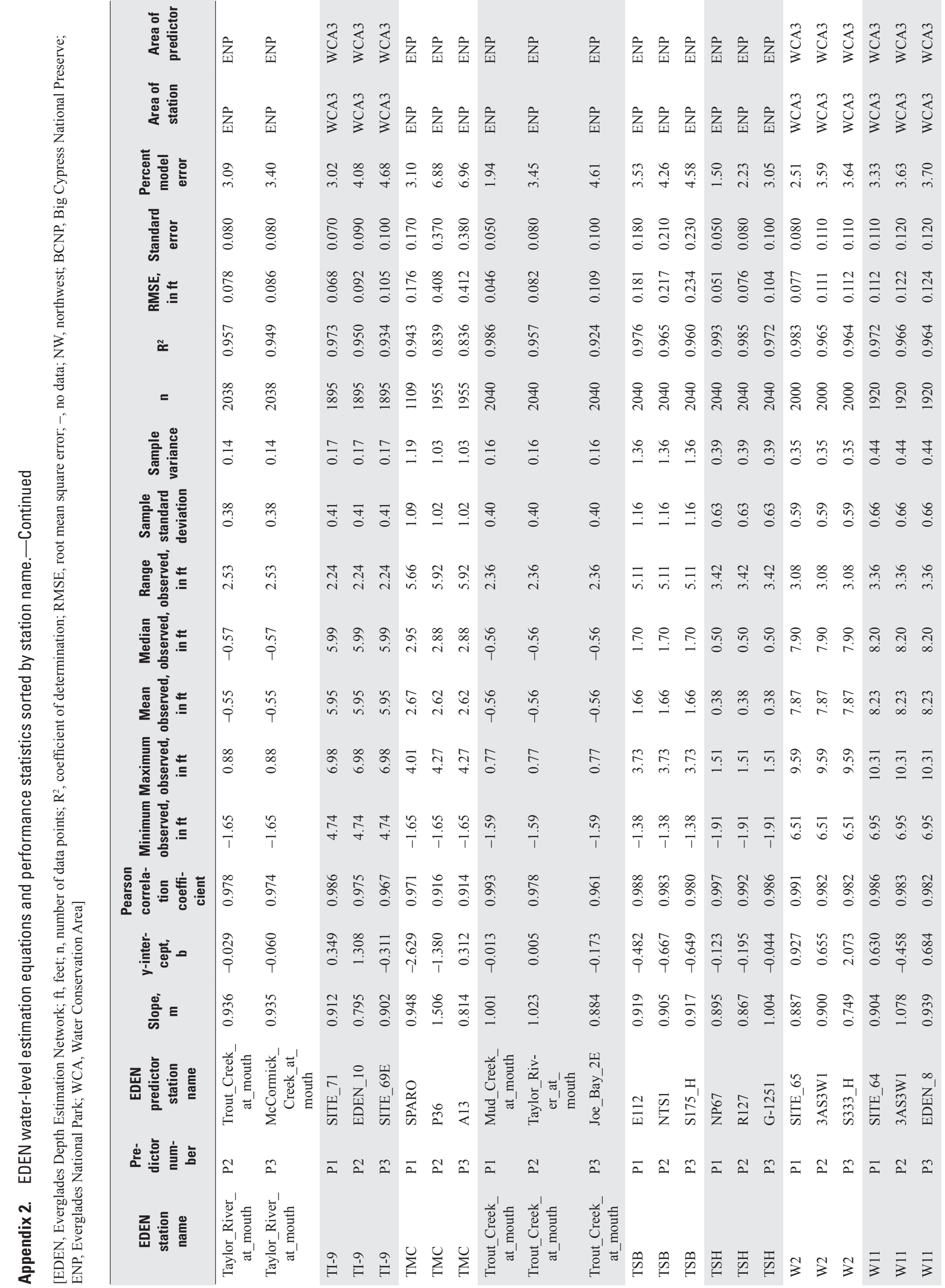




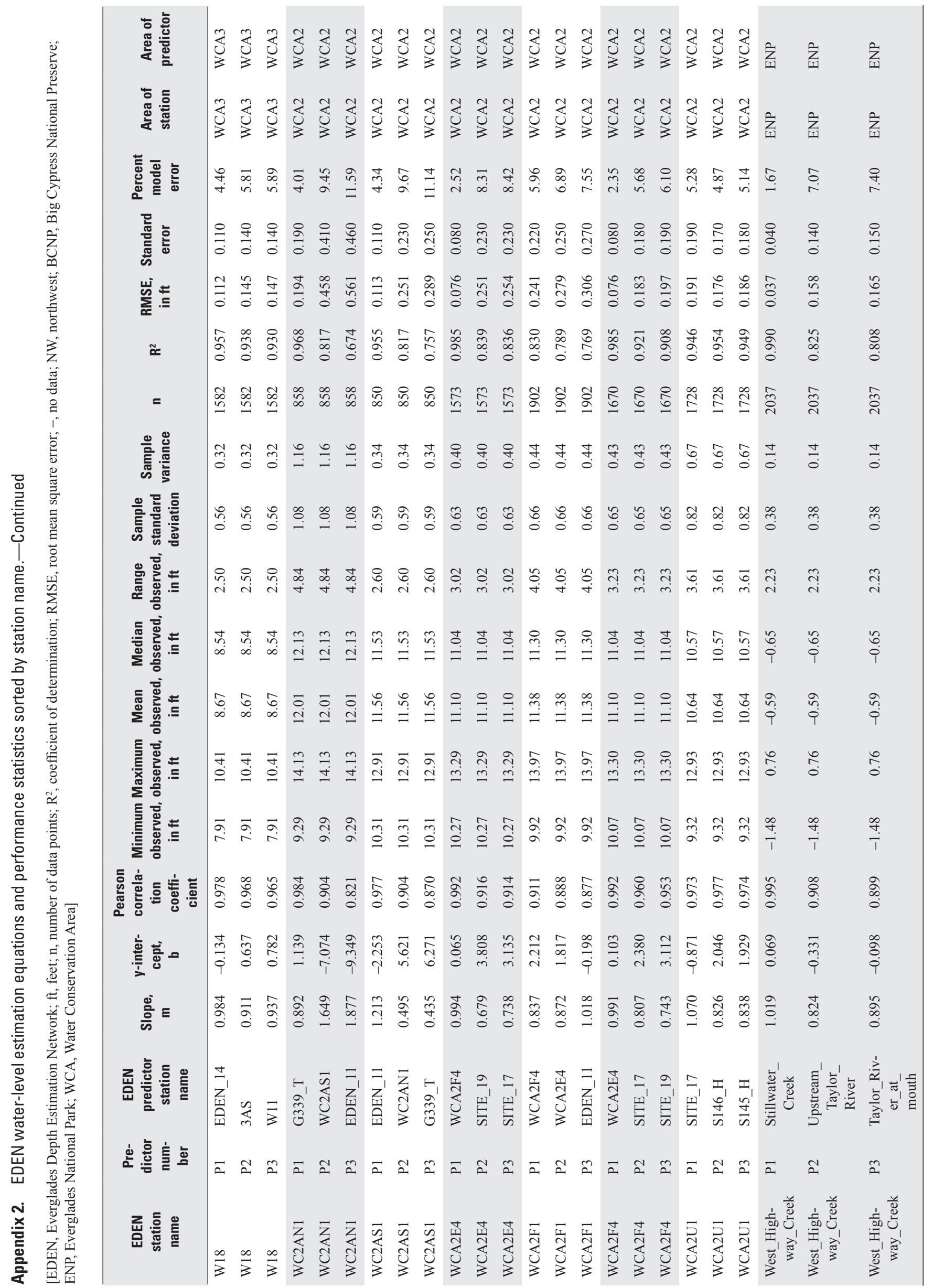


For additional information regarding this publication, contact:

Director

USGS South Carolina Water Science Center

Stephenson Center, Suite 129

720 Gracern Road

Columbia, SC 29210-7651

(803) 750-6100

email:dc_sc@usgs.gov

Or visit the USGS South Carolina Water

Science Center Web site at:

http://sc.water.usgs.gov

Prepared by:

USGS Science Publishing Network

Raleigh Publishing Service Center

3916 Sunset Ridge Road

Raleigh, NC 27607 

